Prepared in cooperation with the

N.J. Department of Environmental Protection

Determination of Baseline Periods of Record for Selected Streamflow-Gaging Stations in New Jersey for Determining Ecologically Relevant Hydrologic Indices (ERHI)

Scientific Investigations Report 2008-5077 



\section{Determination of Baseline Periods of Record for Selected Streamflow-Gaging Stations in New Jersey for Determining Ecologically Relevant Hydrologic Indices (ERHI)}

By Rachel A. Esralew and Ronald J. Baker

Prepared in cooperation with the

N.J. Department of Environmental Protection

Scientific Investigations Report 2008-5077 


\section{U.S. Department of the Interior DIRK KEMPTHORNE, Secretary}

\section{U.S. Geological Survey \\ Mark D. Myers, Director}

\section{U.S. Geological Survey, Reston, Virginia: 2008}

For product and ordering information:

World Wide Web: http://www.usgs.gov/pubprod

Telephone: 1-888-ASK-USGS

For more information on the USGS - the Federal source for science about the Earth,

its natural and living resources, natural hazards, and the environment:

World Wide Web: http://www.usgs.gov

Telephone: 1-888-ASK-USGS

Suggested citation:

Rachel E.A., and Ronald B.J., 2008, Determination of baseline periods of record for selected streamflow-gaging stations in New Jersey for determining Ecologically Relevant Hydrologic Indices (ERHI): U.S. Geological Survey Scientific Investigations Report 2008-5077, 70 p.

Any use of trade, product, or firm names is for descriptive purposes only and does not imply endorsement by the U.S. Government. Use of company names is for identification purposes only and does not imply responsibility.

Although this report is in the public domain, permission must be secured from the individual copyright owners to reproduce any copyrighted material contained within this report. 


\section{Contents}

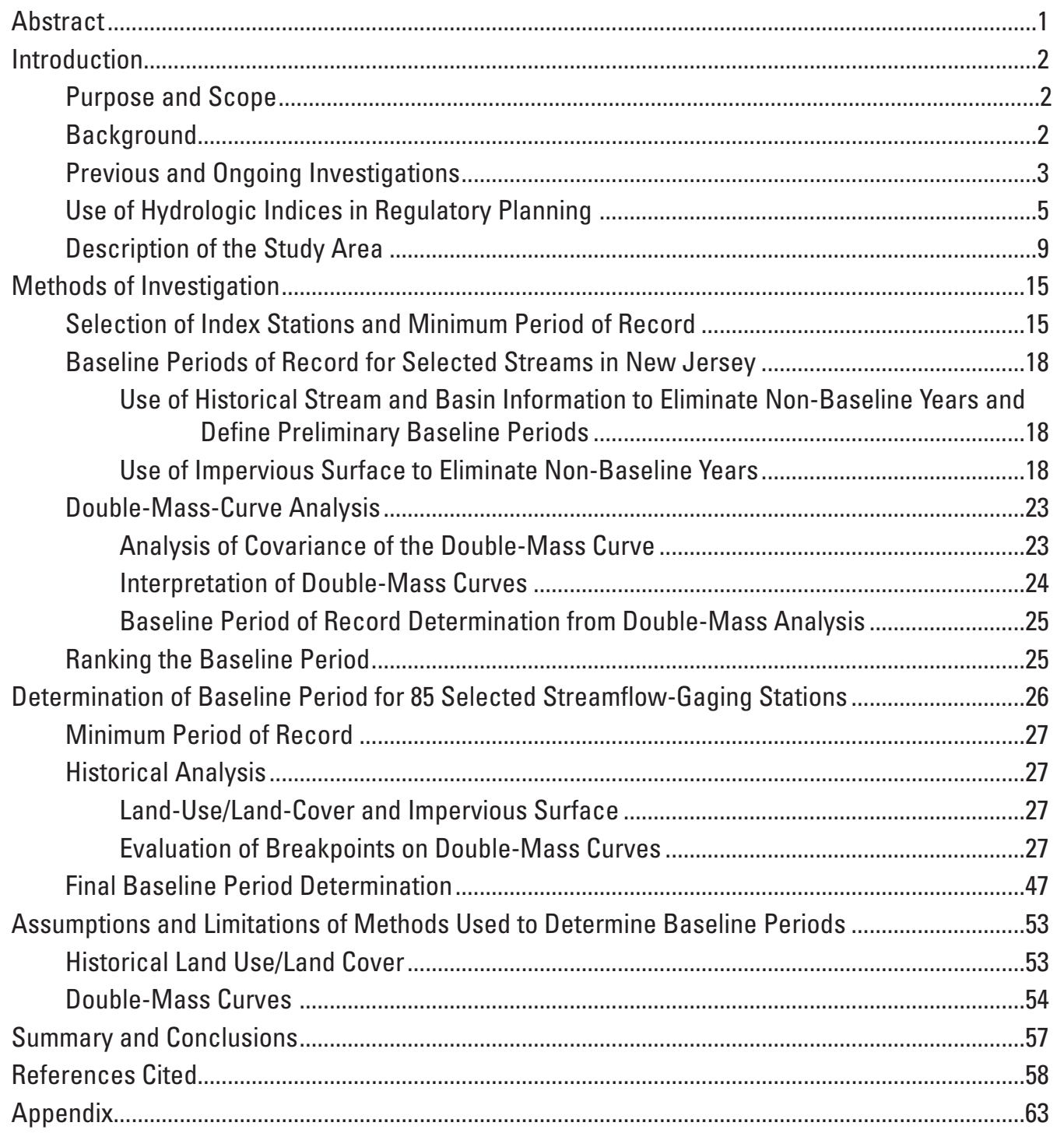




\section{Figures}

1-2. Maps Showing -

1. Location of selected streamflow-gaging stations with stream types and physiographic provinces in New Jersey.

2. Impervious surface from the 1995/97 land-use coverage for all land-use polygon segments and locations of selected streamflow-gaging stations in New Jersey.

3-4. Graphs Showing-

3. Relation of the percentage of impervious surface from 1995-1997 geographic information system (GIS) digital land-use information to population density in persons per square mile for all 570 municipalities in New Jersey.

4. Example of double-mass curves for cumulative annual runoff and base flow at sites with low variability of annual values for selected streamflow gaging stations in New Jersey

5. Flowchart showing the steps for determining baseline periods and the quality of baseline period.

6-7. Graphs Showing-

6. Relation of impervious surface determined from digital geographic information system (GIS) data for 570 municipalities for the years 1995-1997 to impervious surface determined from a mathematical model used to estimate impervious surface using population density for the year 1996

7. Relation of impervious surface determined from digital geographic information system (GIS) data for 85 drainage basins for the years 1995-1997 to impervious surface determined from mathematical model based on population density for the year 1996, for the same 85 drainage basins in New Jersey.

8. Boxplot showing slope ratios at selected statistically significant breakpoints on the double-mass curve for test stations and index stations 


\section{Tables}

1. Description of primary and surrogate ecologically relevant hydrologic Indexes (ERHIs) determined by using the New Jersey Hydrologic Integrity Assessment Process for streams in New Jersey.....

2. Land use at, and continuous period of record for, selected streamflow-gaging stations in New Jersey.

3. Description of seven out (type) streamflow-gaging index stations in New Jersey used to determine minimum periods of record for calculating hydrologic indices and used to develop double-mass curves

4. Selected primary Ecologically Relevant Hydrologic Indices (ERHIs) used to compute the minimum period of record for each stream class at selected streamflow-gaging stations in New Jersey.

5. Means and standard deviations of the percentages of impervious surface for each Type II land use for each polygon segment from the 1995/97 land-use coverage of New Jersey.

6. Baseline period-of-record quality classification based on estimated impervious surface in selected drainage basins in New Jersey...

7. Results of the Kruskall-Wallis test to determine the probability of no difference among groups of numbers of years for seven index stations for each primary hydrologic index type for class $A, B, C$ and $D$, and the minimum number of years for a baseline period

8. Preliminary baseline periods for 85 streamflow-gaging stations in New Jersey and supporting data

9. Estimated percentages of impervious surface and correction factors for drainage basins of selected streamflow-gaging stations in New Jersey

10. Years in which estimated impervious surface in the drainage basins of selected streamflow-gaging stations in New Jersey exceeded 10 percent or 20 percent of the drainage basin area, or had increased by 15 percent.

11. Estimated population density in drainage basins of 83 selected streamflow-gaging stations in New Jersey, by decade.

12. Description of data for selected streamflow-gaging stations and selected index stations in New Jersey sorted by stream type, used to develop double-mass curves

13. Selected results of analysis of covariance conducted on double-mass curves for 85 streamflow-gaging stations and selected index streamflow-gaging stations on the same stream type in New Jersey.

14. Evaluation of breakpoints in double-mass analysis of base-flow and runoff data for selected streamflow-gaging stations in New Jersey.

15. Final baseline period and quality ranking and supporting data for 85 selected streamflow-gaging stations in New Jersey 


\section{Conversion Factors, Datums, Abbreviations and Acronyms}

\begin{tabular}{|c|c|c|}
\hline Multiply & By & To obtain \\
\hline acre & 0.004047 & square kilometer $\left(\mathrm{km}^{2}\right)$ \\
\hline acre & 0.4047 & hectare (ha)) \\
\hline acre & 4,047 & square meter $\left(\mathrm{m}^{2}\right)$ \\
\hline cubic foot per second $\left(\mathrm{ft}^{3} / \mathrm{s}\right)$ & 0.02832 & cubic meter per second $\left(\mathrm{m}^{3} / \mathrm{s}\right)$ \\
\hline foot $(\mathrm{ft})$ & 0.3048 & meter $(\mathrm{m})$ \\
\hline gallon (gal) & 0.003785 & cubic meter $\left(\mathrm{m}^{3}\right)$ \\
\hline gallon (gal) & 3.785 & liter (L) \\
\hline gallon (gal) & 3.785 & cubic decimeter $\left(\mathrm{dm}^{3}\right)$ \\
\hline gallon per day (gal/d) & 0.003785 & cubic meter per day $\left(\mathrm{m}^{3} / \mathrm{d}\right)$ \\
\hline gallon per minute (gal/min) & 0.06309 & liter per second $(\mathrm{L} / \mathrm{s})$ \\
\hline mile (mi) & 1.609 & kilometer $(\mathrm{km})$ \\
\hline million gallons per day (Mgal/d) & 0.04381 & cubic meter per second $\left(\mathrm{m}^{3} / \mathrm{s}\right)$ \\
\hline square foot $\left(\mathrm{ft}^{2}\right)$ & 0.09290 & square meter $\left(\mathrm{m}^{2}\right)$ \\
\hline square foot $\left(\mathrm{ft}^{2}\right)$ & 929.0 & square centimeter $\left(\mathrm{cm}^{2}\right)$ \\
\hline
\end{tabular}

Temperature in degrees Celsius $\left({ }^{\circ} \mathrm{C}\right)$ may be converted to degrees Fahrenheit $\left({ }^{\circ} \mathrm{F}\right)$ as follows:

${ }^{\circ} \mathrm{F}=\left(1.8 x^{\circ} \mathrm{C}\right)+32$

Temperature in degrees Fahrenheit $\left({ }^{\circ} \mathrm{F}\right)$ may be converted to degrees Celsius $\left({ }^{\circ} \mathrm{C}\right)$ as follows:

${ }^{\circ} \mathrm{C}=\left({ }^{\circ} \mathrm{F}-32\right) / 1.8$

Vertical coordinate information is referenced to the insert datum name (and abbreviation) here for instance, "North American Vertical Datum of 1988 (NAVD 88)."

Horizontal coordinate information is referenced to the insert datum name (and abbreviation) here for instance, "North American Datum of 1983 (NAD 83)."

Elevation, as used in this report, refers to distance above the vertical datum. 


\section{Conversion Factors, Datums, Abbreviations and Acronyms-Continued}

\begin{tabular}{|c|c|}
\hline Abbreviations and Acronyms & Meaning \\
\hline 7Q10 & $\begin{array}{l}\text { The lowest streamflow for } 7 \text { consecutive days that occurs on average } \\
\text { once every } 10 \text { years }\end{array}$ \\
\hline BA & Score for breakpoint appearance in a double-mass curve \\
\hline $\mathrm{BP}$ & Score for breakpoint prominence in a double-mass curve \\
\hline $\mathrm{BR}$ & $\begin{array}{l}\text { Breakpoint rating, the final weighted score used to determine the } \\
\text { relative strength of the breakpoint on the double-mass curve }\end{array}$ \\
\hline ERHIs & Ecologically Relevant Hydrologic Indices \\
\hline $\mathrm{FH}$ & The set of ERHIs that express high-flow values \\
\hline FL & The set of ERHIs that express low-flow values \\
\hline FORTRAN (HSPF) & $\begin{array}{l}\text { A comprehensive package for simulation of watershed hydrology and } \\
\text { water quality for both conventional and toxic organic pollutants }\end{array}$ \\
\hline GIS & Geographic information system \\
\hline HIP & Hydroecological Integrity Assessment Process \\
\hline LMM & Local-minimum method of hydrograph-base-flow separation \\
\hline MA24 & The ERHI that expresses the variability of January flow values \\
\hline ML & The set of ERHIs that express magnitude of low-flow values \\
\hline NATHAT & National Hydrologic Assessment Tool \\
\hline NJDEP & New Jersey Department of Environmental Protection \\
\hline NJHAT & New Jersey Hydrological Assessment Toll \\
\hline NJHIP & New Jersey Hydroecological Integrity Assessment Process \\
\hline NJSCT & New Jersey Stream Classification Tool \\
\hline $\mathrm{P}$ & Probability \\
\hline PCA & Principal Component Analysis \\
\hline $\mathrm{r}^{2}$ & Coefficient of determination \\
\hline SR & Score for slope ratio in a double-mass curve \\
\hline $\mathrm{TH}$ & The set of ERHIs that express timing of high-flow values \\
\hline TL & The set of ERHIs that express timing of low-flow values \\
\hline USGS & U.S. Geological Survey \\
\hline
\end{tabular}





\title{
Determination of baseline periods of record for selected streamflow-gaging stations in New Jersey for determining Ecologically Relevant Hydrologic Indices (ERHI)
}

\author{
By Rachel A. Esralew and Ronald J. Baker
}

\begin{abstract}
Hydrologic changes in New Jersey stream basins resulting from human activity can affect the flow and ecology of the streams. To assess future changes in streamflow resulting from human activity an understanding of the natural variability of streamflow is needed. The natural variability can be classified using Ecologically Relevant Hydrologic Indices (ERHIs). ERHIs are defined as selected streamflow statistics that characterize elements of the flow regime that substantially affect biological health and ecological sustainability. ERHIs are used to quantitatively characterize aspects of the streamflow regime, including magnitude, duration, frequency, timing, and rate of change. Changes in ERHI values can occur as a result of human activity, and changes in ERHIs over time at various stream locations can provide information about the degree of alteration in aquatic ecosystems at or near those locations. New Jersey streams can be divided into four classes (A, B, C, or D), where streams with similar ERHI values (determined from cluster analysis) are assigned the same stream class.

In order to detect and quantify changes in ERHIs at selected streamflow-gaging stations, a "baseline" period is needed. Ideally, a baseline period is a period of continuous daily streamflow record at a gaging station where human activity along the contributing stream reach or in the stream's basin is minimal. Because substantial urbanization and other development had already occurred before continuous streamflow-gaging stations were installed, it is not possible to identify baseline periods that meet this criterion for many reaches in New Jersey. Therefore, the baseline period for a considerably altered basin can be defined as a period prior to a substantial human-induced change in the drainage basin or stream reach (such as regulations or diversions), or a period during which development did not change substantially.

Index stations (stations with minimal urbanization) were defined as streamflow-gaging stations in basins that contain less than 15 percent urban land use throughout the period of continuous streamflow record. A minimum baseline period of record for each stream class was determined by comparing the
\end{abstract}

variability of selected ERHIs among consecutive 5-, 10-, 15-, and 20-year time increments for index stations. On the basis of this analysis, stream classes $\mathrm{A}$ and $\mathrm{D}$ were assigned a minimum of 20 years of continuous record as a baseline period and stream classes B and C, a minimum of 10 years.

Baseline periods were calculated for 85 streamflow-gaging stations in New Jersey with 10 or more years of continuous daily streamflow data, and the values of 171 ERHIs also were calculated for these baseline periods for each station. Baseline periods were determined by using historical streamflow-gaging station data, estimated changes in impervious surface in the drainage basin, and statistically significant changes in annual base flow and runoff.

Historical records were reviewed to identify years during which regulation, diversions, or withdrawals occurred in the drainage basins. Such years were not included in baseline periods of record. For some sites, the baseline period of record was shorter than the minimum period of record specified for the given stream class. In such cases, the baseline period was rated as "poor."

Impervious surface was used as an indicator of urbanization and change in streamflow characteristics owing to increases in storm runoff and decreases in base flow. Percentages of impervious surface were estimated for 85 streamflowgaging stations from available municipal population-density data by using a regression model. Where the period of record was sufficiently long, all years after the impervious surface exceeded 10 to 20 percent were excluded from the baseline period. The percentage of impervious surface also was used as a criterion in assigning qualitative ratings to baseline periods.

Changes in trends of annual base flow and runoff were determined by using double-mass curves, in which cumulative discharge at a test station (x-axis) is plotted in relation to cumulative discharge at an index station (y-axis) of the same stream class. The slope of the double-mass curve is expected to remain constant unless there have been changes in the drainage basin of the test station that altered hydrologic processes. The significance of changes in the slope of the relation (breakpoints) was evaluated by analysis of covariance and visual inspection. 
A final baseline period was determined for each test station by using a combination of historical records, changes in impervious surface, and double-mass analysis. The baseline period for each station was rated as excellent, good, fair, or poor by using a numerical rating procedure based on length of record, percentage of impervious surface and the results of double-mass analysis. Values for all 171 ERHI were calculated for the baseline periods of each of the 85 stations. Stream class was then determined for each test station.

\section{Introduction}

The population of New Jersey has increased from about 5 million in 1950 to 8.1 million in 2000 and continues to increase (United States Census Bureau, 2000). As the population increases, demands on the State's water resources also increase. Withdrawals of ground water and diversions of surface water lead to reduced stream base flow, and increases in impervious surface lead to increased stormwater runoff. Because of these changes, water-resources managers have regulated peak streamflow to protect property from flood damage and low flow to maintain minimum passing flows. Changes to the natural flow regime that result from increased development and direct physical alteration of streamflow patterns can affect aquatic ecosystems. Because human activity in New Jersey basins is increasing, an improved understanding of the relations between development, streamflow, and aquatic ecosystems is needed. An understanding of the natural variability of streamflow will enable water managers to assess the effects of future changes in streamflow that may threaten the ecological health of streams and surrounding areas. This natural variability can be quantified by using Ecologically Relevant Hydrologic Indices (ERHIs), which are statistics calculated from the seasonal patterning of flows; timing of extreme flows; the frequency, predictability, and duration of floods, droughts, and intermittent flows; daily, seasonal, and annual flow variability; and rates of change (Poff and others, 1997). ERHI values are determined for a baseline period for areas where human alteration to the environment along the stream reach or in a basin is relatively minimal. ERHI values for future periods can be compared to those for a baseline period to determine the change in streamflow.

The purpose of this investigation, conducted in cooperation with the New Jersey Department of Environmental Protection (NJDEP), was to determine ERHIs for streams throughout New Jersey during baseline periods. Changes in values of ERHIs from the baseline period to current or future streamflow conditions can be used as indicators of ecological conditions of a stream because central tendencies and extremes of the flow regime directly affect the habitats of biota in and near the stream. Baseline periods were determined by (A) defining the minimum period of record for each stream class, (B) determining when alterations occurred in drainage basins by reviewing historical records, (C) estimating changes in impervious surface in each basin over time, and (D) using double-mass curves to determine when hydrologic changes occurred in streams by comparing cumulative discharge to that of index streams. The baseline periods determined from this investigation are considered refinements of the baseline period of record selected for the original New Jersey Hydroecological Integrity Assessment Process (NJHIP) stream classification (Henriksen and others, 2006; Kennen and others, 2007).

\section{Purpose and Scope}

This report describes the determination of baseline periods of record for 85 gaged streams in New Jersey with over 10 years of continuous streamflow data available. Methods of utilizing historical information about stations and basins, and double-mass-curve analysis, to assign baseline periods are presented. Also described is the calculation of values for the 171 ERHIs for the 85 selected gaging stations using streamflow data collected during the baseline period of record.

\section{Background}

The New Jersey Department of Environmental Protection (NJDEP) has responsibilities, through regulatory and planning programs, for the management of water resources and land use, while concurrently protecting and managing riverineassociated fish and wildlife resources (New Jersey Department of Environmental Science, 2008). A "passing flow" is often required as part of a water allocation permit (Wahl and others, 1995). This passing flow requirement typically uses the 7-day, 10-year low-flow statistic (7Q10). This flow requirement focuses only on duration and magnitude of low flows, and does not consider the full scope of hydrologic characteristics needed to adequately preserve in-stream aquatic ecology. Consequently there is a need to identify an ecologically based and scientifically defensible approach for establishing flow regulations that adequately protect the natural ecology of streams. To achieve this, minimum-flow approaches (for example, 7Q10) may be complemented with interdisciplinary approaches that consider the complex nature of the flow regime and the ways in which human activities in the drainage basin affect the ecology of streams.

Streamflow characteristics that constitute the natural flow regime include magnitude, frequency, duration, timing, and the rate of change of low, average, and peak streamflow (Poff and others, 1997). Researchers have developed 171 ERHIs to assess the variability of the flow regime and its effect on biological resources (Olden and Poff, 2003). These ERHIs have been developed to characterize the flow regime in terms of biologically relevant flow variables, quantify short-term and long-term variability in patterns of the flow regime, and identify characteristics of streamflow that may be sensitive to human alterations in the drainage basin. Examples of ERHIs that have been investigated for their role in ecosystem functionality include average flow conditions, variations in 
mean daily flow, predictability of high- and low-flow events, skewness in flow and peak discharges, flood frequency and frequency curve slopes, seasonal distributions of monthly flows, duration of high and low flows, and rates of change in patterns of annual discharges (Olden and Poff, 2003).

\section{Previous and Ongoing Investigations}

Poff and Ward (1989) examined 78 U.S. streams for overall flow variability and predictability, flood regime patterns, the extent of intermittency, and associated lotic population and community attributes with these parameters. They used cluster analysis to identify nine stream types based on streamflow variability in long-term discharge records. The stream types were described as harsh intermittent, intermittent flashy, intermittent runoff, perennial flashy, perennial runoff, snowmelt, snow plus rain, winter rain, and mesic ground water. Stream types were found to be geographically affiliated.

Olden and Poff (2003) studied 171 ERHIs that had been reported in previous literature. Their objective was to create a smaller set of ERHIs that adequately describe streamflow characteristics without redundancy. Through the use of principal component analysis (PCA), they found that many of the 171 ERHIs describe similar characteristics of the flow regime and, therefore, are redundant. Ten important streamflow characteristics were identified as the magnitudes of high, low, and average flows; the frequency, duration, and timing of high and low flows; and the rate of change of average flow. Six stream classes were identified on the basis of streamflow patterns observed for 420 streamflow-gaging stations. PCA was then used to select nine statistically significant, nonredundant ERHIs, referred to as primary ERHIs, for each of the six stream classes. Additional ERHIs were identified that can be used as surrogates (Olden and Poff, 2003).

Using methods developed by Olden and Poff (2003), U.S. Geological Survey (USGS) researchers (Henriksen and others, 2006) developed the Hydroecological Integrity Assessment Process (HIP), which is a software tool that can identify a set of 10 primary ERHIs that describe the streamflow characteristics at a gaging station and calculate the values of those ERHIs. USGS researchers also developed the National Hydrologic Assessment Tool (NATHAT), a software application that can be used to determine variability in values of ERHIs based on daily hydrographs. This software application can be used to calculate ERHIs for any stream with daily streamflow and peak-flow data.

To use NATHAT a stream reach is first classified as one of six stream classes. This method at the national level may not yield results that are specific enough to adequately classify streams at a local level and could result in non-optimal selection of ERHIs for a local stream reach. For example, in the national study, seven streams in New Jersey were evaluated and were classified as only two of the perennial stream classes (Olden and Poff, 2003). To make HIP and the NATHAT program more applicable to specific regions or basins, USGS has been working with agencies in several States, including New Jersey, Massachusetts, and Missouri, to develop new sets of stream classifications that more adequately reflect streamflow conditions in local stream reaches. Henriksen and others (2006) adapted the stream classification and ERHI determination procedure from the national HIP and applied the process to hydrologic conditions that are present in New Jersey streams, and created the tool NJHIP.

NJHIP involved development of new stream classifications for New Jersey streams and subsequent identification of sets of primary and surrogate ERHIs for each stream class. In order to classify streams in New Jersey, a preliminary baseline period of record was identified as the period during which streamflow was least affected by human activity. This baseline was selected on the basis of the history of the streamflowgaging station, such as visual interpretation of anomalies in hydrographs, and trends in streamflow data reported in previous studies (J.G. Kennen, U.S. Geological Survey written commun., 2006). Those baseline periods for 95 streamflowgaging stations are listed in Henriksen and others (2006). Cluster analysis was used to categorize streams in New Jersey at 95 gaging stations into four stream classes (A,B,C, and D). The four stream classes are characterized by differences in basin area, relative degree of skewness of daily flows, and frequency of low-flow events (Henriksen and others, 2006). Streams with high skewness of daily flows reach peak flow rapidly compared to the rate at which they return to base flow and are termed flashy. It was determined that streams belonging to stream class A tend to be moderately flashy with moderately low base flow. Class B streams tend to be stable with high base flow. Class $\mathrm{C}$ streams tend to be moderately stable with moderately high base flow, and class $\mathrm{D}$ streams tend to be flashy with low base flow. Classification can differ among the streams. The spatial distribution of stream classes throughout New Jersey is shown in figure 1. PCA was used to identify the 10 primary and additional surrogate ERHIs from the 171 ERHIs investigated by Olden and Poff (2003) for each stream class (Henriksen and others, 2006).

Watson and others (2005) evaluated trends in streamflow and the relation between these trends and land-use patterns in New Jersey. Annual streamflow variability and trends in 1-, 7and 30-day low and high flows were evaluated for 111 streamflow-gaging stations (including the 85 used in this investigation) with 20 or more years of record. They found significant relations between high flows and streams that are regulated, and high flows and development in the basin. The study also demonstrated that the relation between low-flow trends and development was not as strong as that for the high-flow trends. Streamflow variability was found to be significantly greater at streamflow-gaging stations located outside the Coastal Plain than in the Coastal Plain.

Urbanization is defined here as the conversion of agricultural and forested areas to urban land use. Impervious surface (highly compacted soil, pavements, and roof tops) is increased during urbanization, and infiltration of water into the soil is decreased (Arnold and Gibbons, 1996). Thus, the volume and 


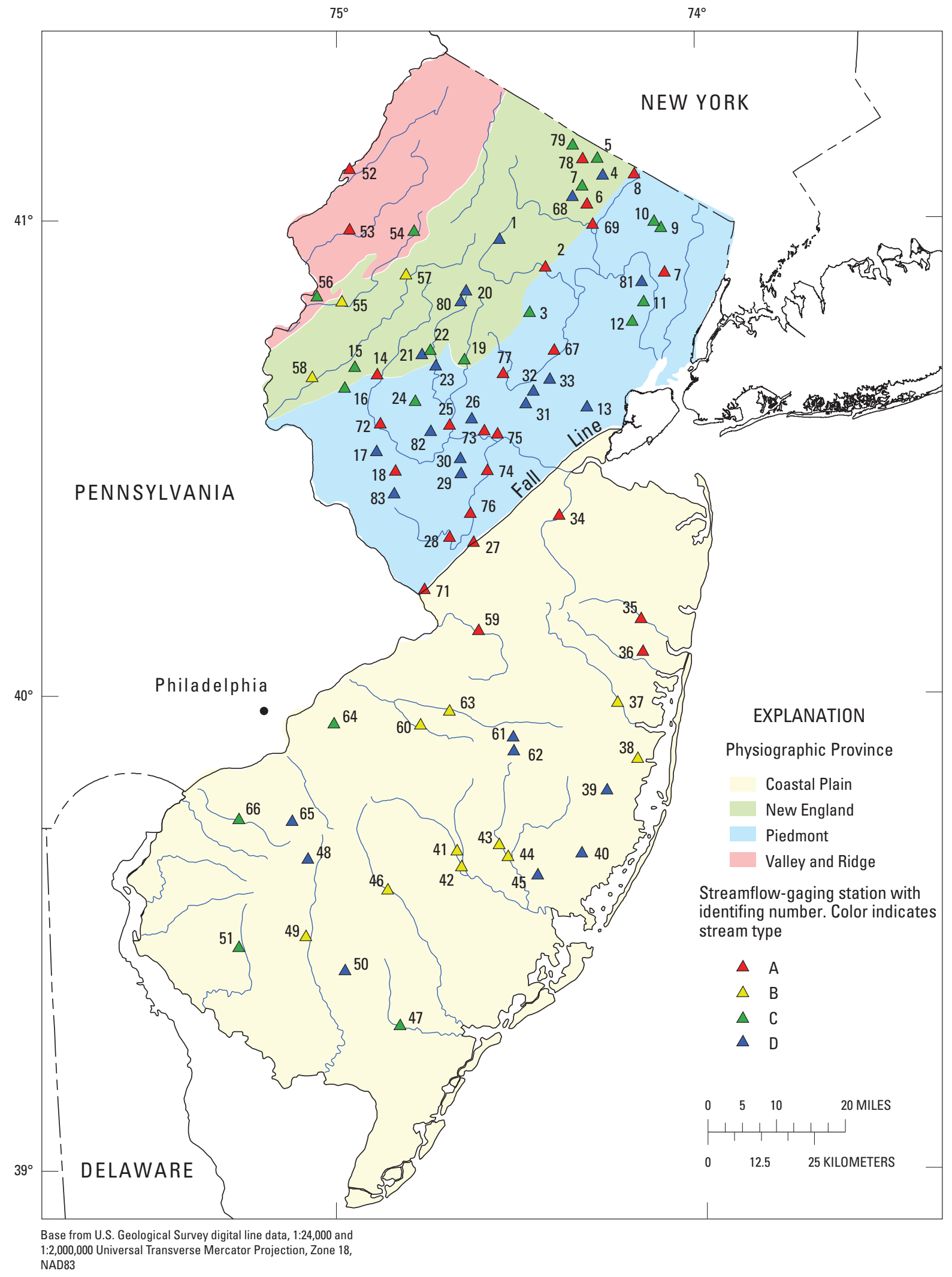

Figure 1. Location of selected streamflow-gaging stations with stream types and physiographic provinces in New Jersey. 
rate of streamflow in urban areas can increase during times of stormwater runoff and decrease during times of low flow compared with streamflow in agricultural and forested areas. Also, periods of low flow can be extended between precipitation events. These changes in the flow regime can cause disturbance to aquatic habitats (Konrad, 2003; Konrad and Booth, 2002; Kennen and Ayers, 2002).

Impervious surfaces can serve as an indicator of urban development and other human activity in the basin. The increase in impervious surfaces as a result of population growth accelerated in the early 20th century with the proliferation of the automobile and construction of road systems (Arnold and Gibbons, 1996). Improved transportation networks generally stimulate and facilitate growth, leading to further urbanization and increases in impervious surface.

Stankowski (1972) found a significant correlation between the percentage of impervious surface and population density in 570 municipalities in New Jersey. He found that impervious surface varies with, and can be reliably estimated from, land-use type. Alley and Veenhuis (1983) found that percentages of total impervious surface in the Denver, Colorado, area were related to land-use patterns. They assigned values of 20 percent total impervious surface for low-density residential development, 35 percent for medium-density suburban development, 60 percent for high-density urban development, and 90 percent for commercial, industrial, and transportation facilities.

Change in impervious surface can be used to define boundaries of baseline periods as impervious surface is easily measurable and is strongly correlated with urbanization. Previous investigations have considered the relations between impervious surface and hydrologic processes and its effects on the health of aquatic habitat. Brun and Band (2000) used digital spatial data and the Hydrologic Simulation Program Fortran (HSPF) to assess the effects of land-use changes on basin behavior in Baltimore, Maryland, from "pre-urbanized times" to 1990. They identified a threshold of impervious cover, 20 percent, above which the ratio of runoff to base flow changes substantially.

When relating impervious surface to aquatic health, it is difficult to separate the effects of other environmental stressors resulting from human activity, including non-point sources constituent loading from runoff and vegetation removal. Arnold and Gibbons (1996) and Schueler (1994) reviewed the results of previous stream water-quality studies and concluded that 10 percent impervious surface was a generally accepted threshold for "impacted stream health" and 30 percent for "degraded" status. Kennen and Ayers (2002) used principal component analyses and multiple-linear regression to evaluate the response of fish, invertebrates, and algae in 36 basins in New Jersey to environmental characteristics along a gradient of urban land use that ranged from 3 to 96 percent of the drainage basin. Environmental characteristics that substantially affected species assemblages included impervious surface, human population, nutrient concentrations, and forested and wetland areas. By eliminating redundant variables, they were able to relate impervious surface to aquatic health and found that an impervious surface coverage greater than 18 percent was associated with moderate to severe ecological impairment.

Natural vegetative land cover helps to regulate streamflow. Forest canopy and leaf litter, for example, increase evapotranspiration and reduce runoff, erosion, and sedimentation (Field, 1997). By replacing natural land cover with crop or pasture land, agricultural land use can increase sedimentation and channel-bed erosion, which may alter flood plain and channel dynamics (Fitzpatrick and others, 1999).

\section{Use of Hydrologic Indices in Regulatory Planning}

NJHIP can be used by water-resources managers to assess the effects of past and proposed alterations to the flow regime on the values and patterns in ERHIs. The USGS, in a 4-year cooperative study with NJDEP, has used NJHIP to develop two software applications to assist in the use of NJHIP. These software applications are the New Jersey Stream Classification Tool (NJSCT) and the New Jersey Hydrologic Assessment Tool (NJHAT). NJSCT can be used to classify streams that were previously unclassified in the NJHIP as class A, B, C, or D. NJHAT calculates values of all 171 ERHIs and identifies on the basis of stream class those ERHIs that serve as primary or surrogate indices. These software tools are used with publicly available USGS streamflow data.

The ERHIs identified by NJHIP can be defined as either temporal or spatial (Henriksen and others, 2006). Temporal indices are calculated from long-term multi-year daily flow records for a single streamflow-gaging station. For example, to calculate the ERHI MA24-variability of January flow values - the standard deviation of January daily mean flow values is divided by the corresponding mean daily flow for each year of record, and the median of these values is the index value. NJHAT provides an option for calculating upper and lower percentile limits for temporal indices, and the 25th and 75 th percentiles (first and third quartiles) are the default values.

Water managers can use hydrologic indices to predict the effects of proposed water withdrawals on streamflow characteristics, which can help them to meet a regulatory objective of protecting in-stream aquatic ecology while managing water use. Definitions of all 171 hydrological indices are given by Kennen and others (2007). The set of primary and surrogate indices specified by NJHIP and selected by the program NJHAT does not meet the regulatory objectives of NJDEP (J.L. Hoffman, New Jersey Department of Environmental Protection, written commun., 2006). Therefore, new primary indices were developed that are more suitable for use by water managers (table 1). The criteria used to select the new set of indices are described in this section.

Many of the frequency of high flow and frequency of low flow indices (FH and FL, respectively) are based on a 


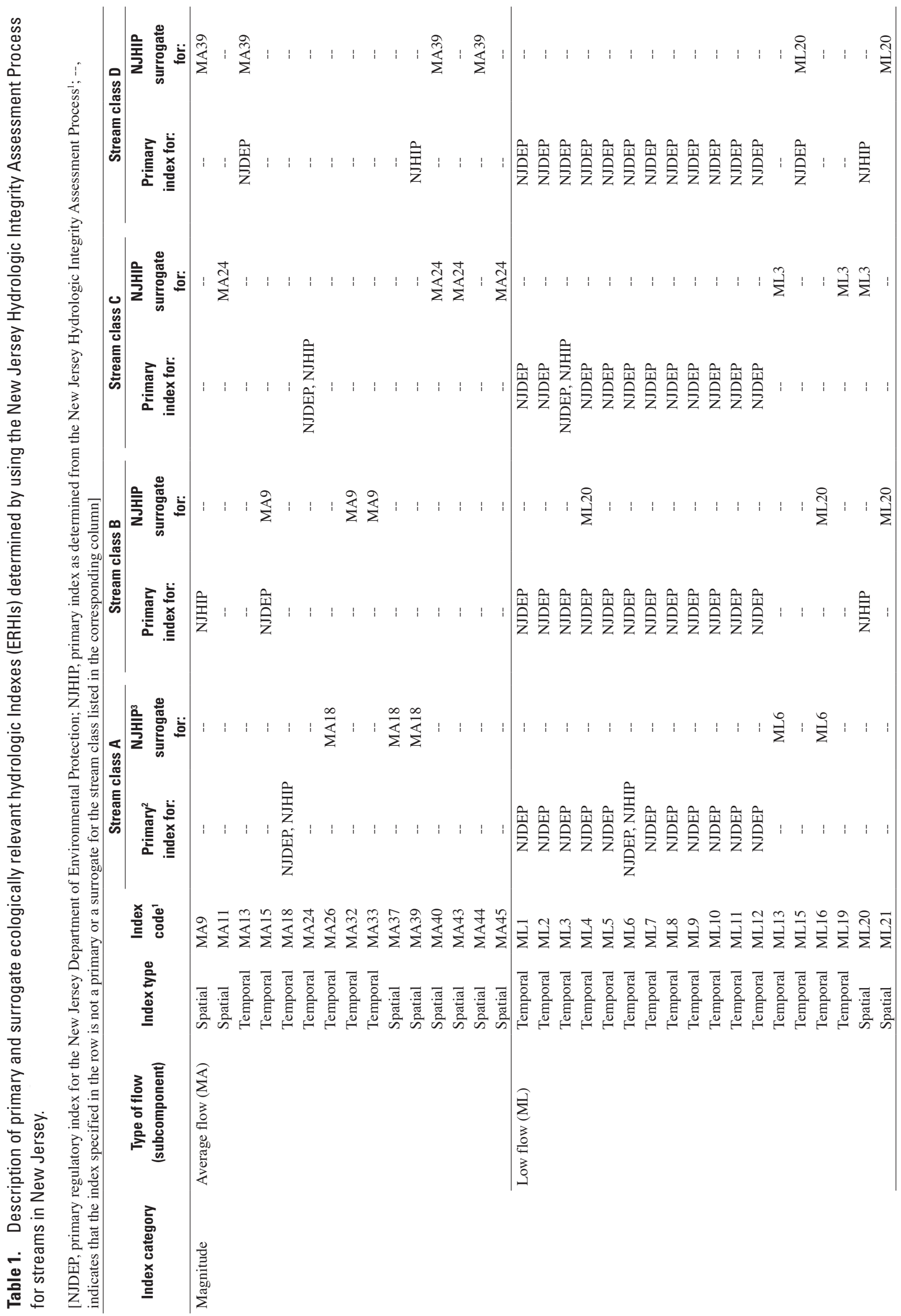




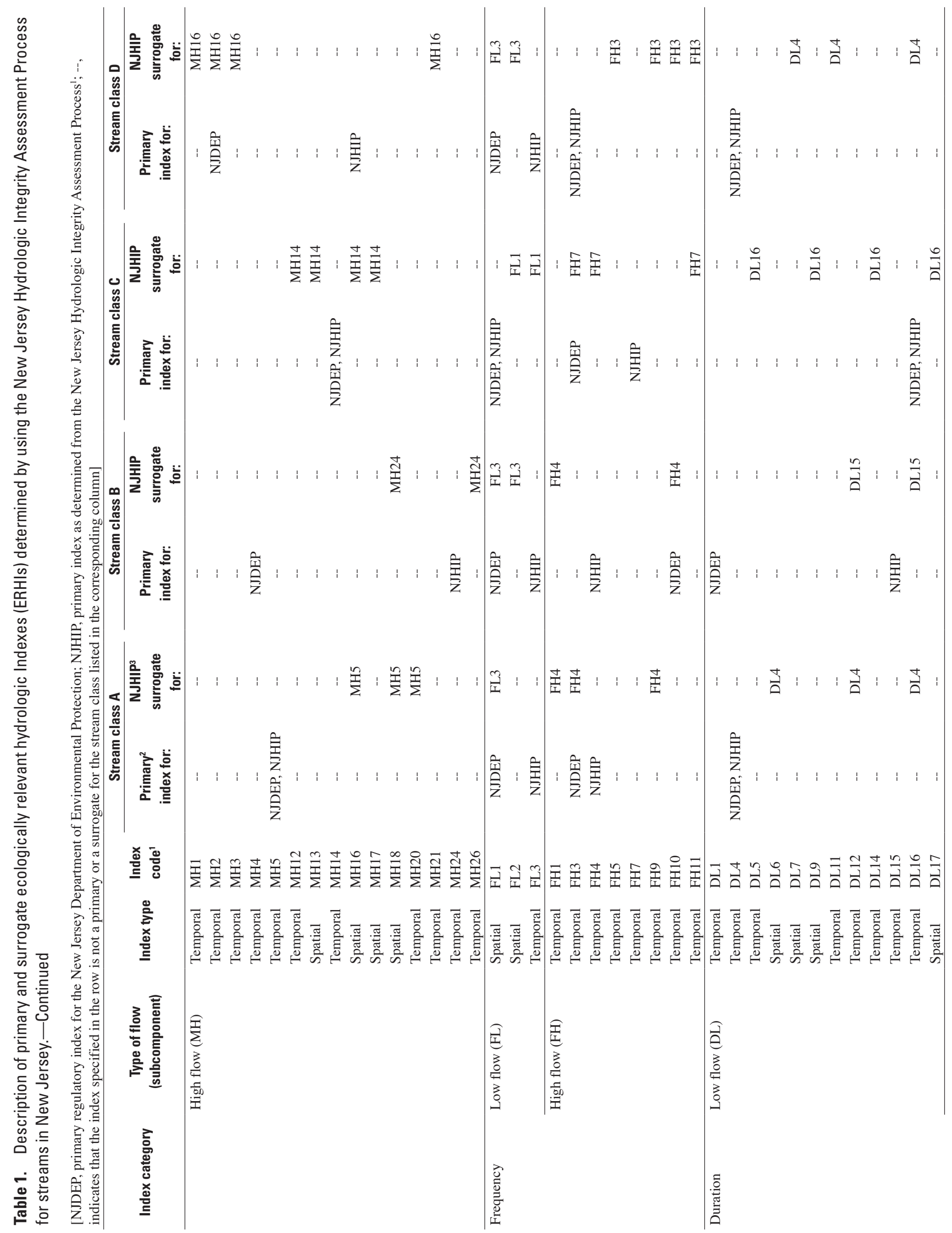




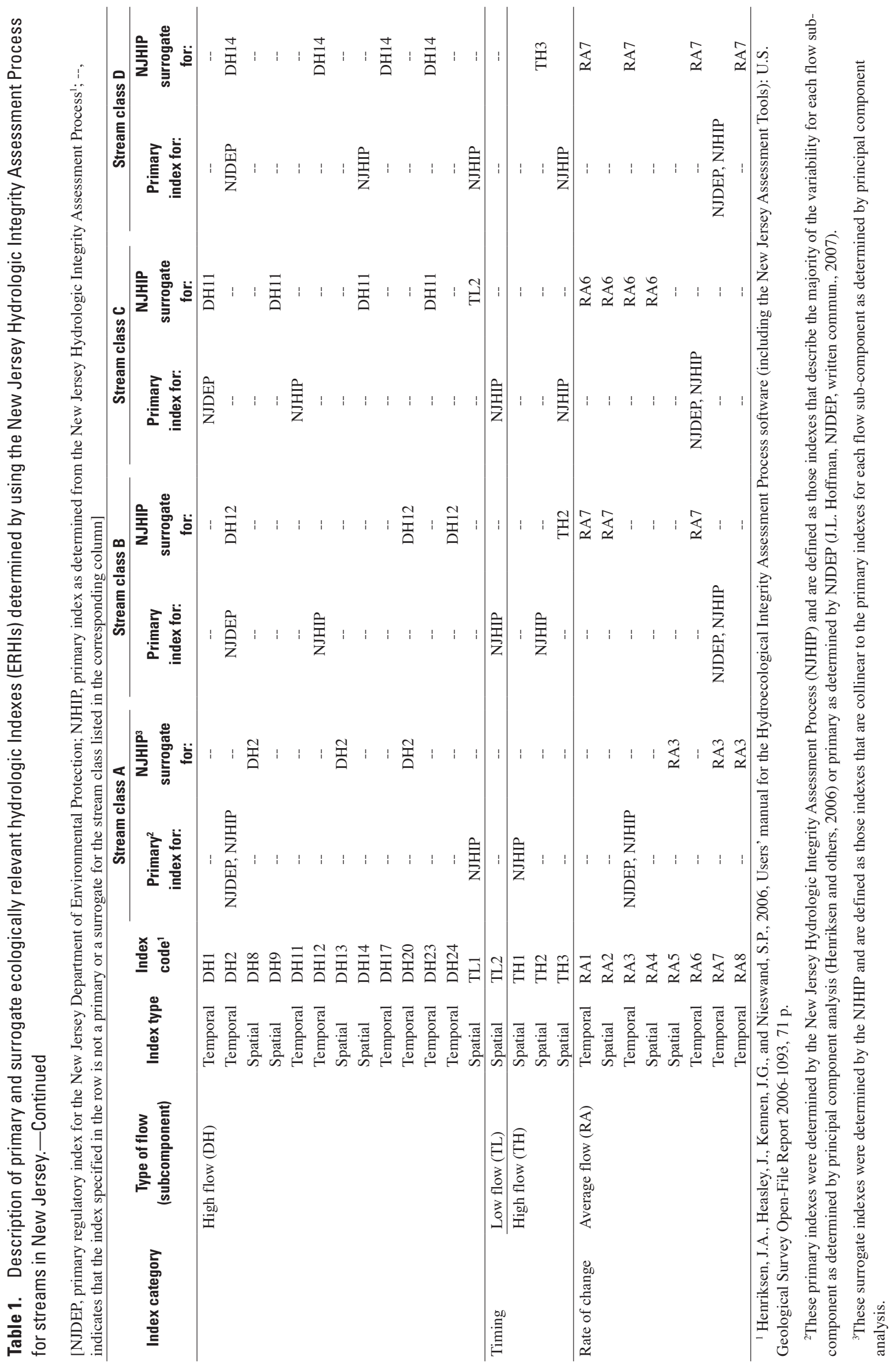


variable of frequency of occurrence. If there is little variability in streamflow, these ERHI values may equal zero, meaning that event described by the ERHI never occurs. This has limited regulatory value where upper and lower percentiles of frequency of occurrence are used as regulatory thresholds. Therefore, temporal primary and surrogate frequency indices were selected that are expected to yield more dynamic ranges of index values (non-zero values). Removal of spatial indices from consideration resulted in the elimination of all indices that describe timing of low flow and timing of high flows (TL and TH indices). To compensate for this, NJDEP designated 12 magnitude-of-low-flow (ML) indices as primary indices. This provides information about the seasonal variability of streamflow (J.L. Hoffman, New Jersey Department of Environmental Protection, written commun., 2006).

Many index values can be calculated using median values instead of mean values. For example, index MA24-variability (coefficient of variation) of January flow values - uses the standard deviation of January daily mean flow values divided by the corresponding mean daily flow for each year of record, and the mean of these values is the index value. In place of a mean, a median of these values also can be calculated as an index value. The mean is the default calculation for many indices in NJHAT, but calculation of a median can be selected as a default in the software configuration. All primary and surrogate temporal indices selected by NJDEP use only median (not mean) streamflow values.

\section{Description of the Study Area}

Eighty-five streamflow-gaging stations throughout New Jersey with 10 or more years of continuous streamflow data (table 2) were selected for this investigation. Originally 95 stations had been proposed, but 10 of these stations did not have sufficient years of baseline record as a result of extensive regulation, diversion, ground-water withdrawal, or other human alterations (R.D. Schopp, U.S. Geological Survey, oral commun., 2006).

The study area (fig. 1), which includes the entire state of New Jersey and parts of New York, covers approximately 8,100 square miles. All streamflow-gaging stations are located in New Jersey; however, portions of drainage basins upstream from eight stations are located in New York State. The study area has a population of more than 8.6 million people and includes some of the most densely populated metropolitan areas in the United States (United States Census Bureau, 2005). New Jersey comprises four physiographic provinces, as described by the NJDEP (2007) - the Valley and Ridge; New England; Piedmont, which is north of the Fall Line; and the Coastal Plain, south of the Fall Line. The lithology of the provinces north of the Fall Line consists mostly of sedimentary and crystalline rock, shale, and sandstone. The Valley and Ridge Physiographic Province is characterized by a series of parallel ridges and valleys trending northeast-southwest with mountainous topography and elevations exceeding $480 \mathrm{~m}$. The
New England Physiographic Province consists of broad, flattopped highlands and long, narrow valleys that range in elevation from 150 to $460 \mathrm{~m}$. The Piedmont Physiographic Province consists of northwestward-dipping sedimentary rocks that form broad, gently sloping lowlands and rolling hills, where elevations typically reach only $120 \mathrm{~m}$. The Coastal Plain is dominated by gravel, sand, silt, and clays. About 55 percent of the study area is in the Coastal Plain physiographic province, which is characterized by flat to gently rolling topography and unconsolidated sedimentary deposits (Wolfe, 1977).

Streamflow in the Piedmont Physiographic Province is highly variable (flashy) owing to limited ground-water recharge. In the Coastal Plain, however, ground-water discharge is substantial, and streamflow is relatively stable. In the Highlands and Valley and Ridge Provinces, streamflow tends to fall somewhere between the flashy flows of the Piedmont and the more stable ground-water-supported flows of the Coastal Plain. Ground water contributes 65 to 95 percent of the base flow in the Coastal Plain. North of the Fall Line the ground-water contribution to base flow ranges from approximately 22 to 88 percent. In general, streamflow in the northern part of the study area is dominated by surface runoff; in the Coastal Plain, it is dominated by flow from ground-water sources (Watt, 2000).

Over the past century, New Jersey has experienced extensive human alteration with the conversion of large areas of agricultural and some undeveloped land to urban and suburban developments. Such changes are likely to cause changes in the hydrologic flow regime in streams (Kennen and Ayers, 2002). These large-scale changes in population and land-use have left few streams unaffected by human activities. Stream regulation, addition of dams and reservoirs, wastewater discharge, surface-water and ground-water withdrawal in the drainage basin, and changes resulting from the suburbanization of farmland and forest or the reforestation of farmland are all capable of altering the streamflow regime. From 1970 to 2000 there has been a greater than 40-percent increase in urbanized land and a subsequent decrease in other land-use categories, most notably agricultural land. As a result of these changes, most of northeastern New Jersey and the corridor between New York City and Philadelphia have experienced urbanization of land, ranging from small roads and suburban tracts to high-density commercial, industrial, and residential development. This urbanization increases the amount of impervious surface area, which results in an increased rate of runoff during precipitation, and delays and decreases base-flow contributions to streams in these areas. Water-supply systems in the study area are highly interconnected, and transfer of water across drainage divides and among basins is common. For example, nearly 80 million gallons per day of water is transferred from the Delaware River to the Raritan River basin by way of the Delaware and Raritan canal (Ayers and others, 2000).

The climate in New Jersey is considered temperate, with an average temperature of $52.1^{\circ} \mathrm{F}$ and average annual precipitation of $113.6 \mathrm{~cm}$ based on data from 1895 to 2002. Precipitation in the study area can be further subdivided into three 


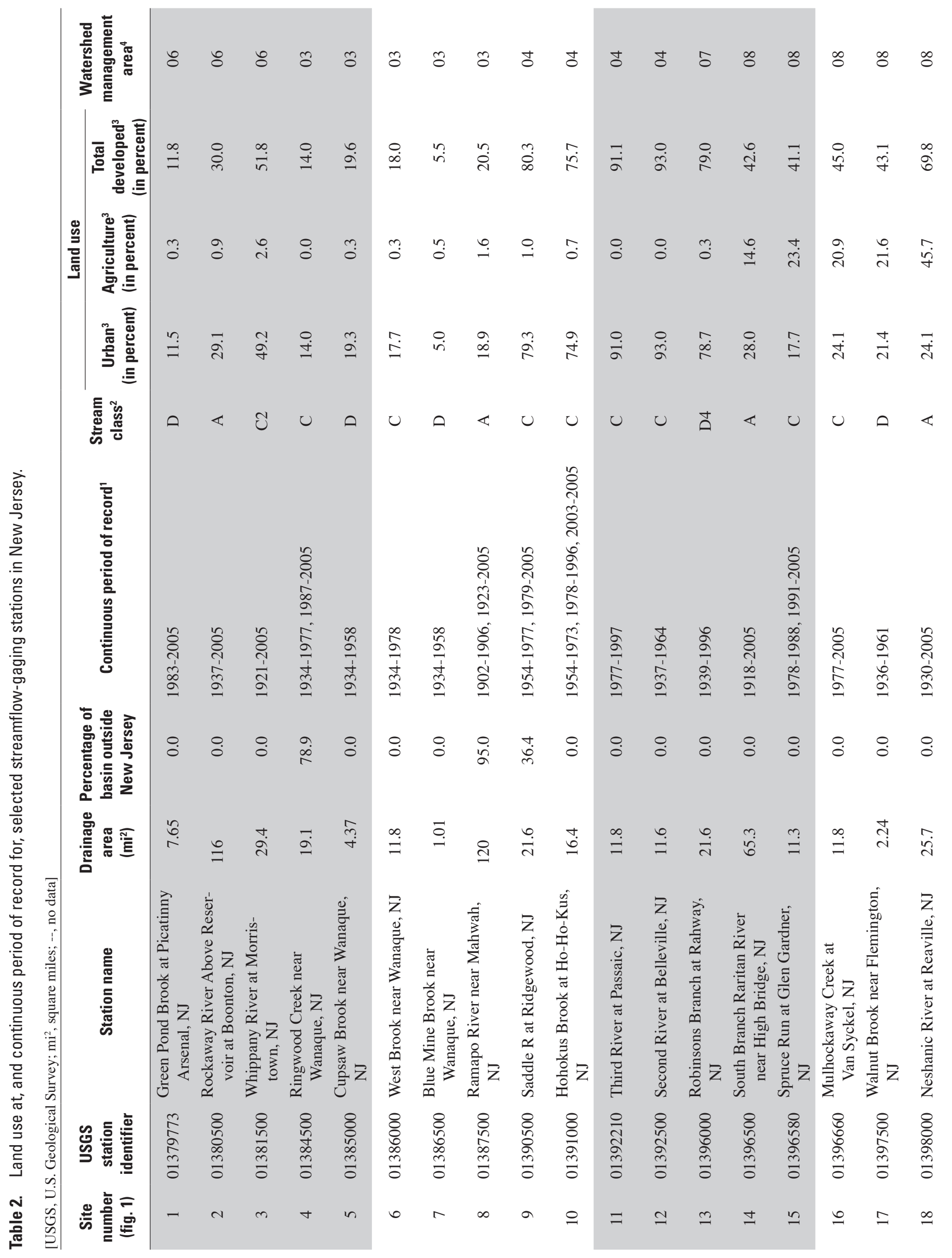




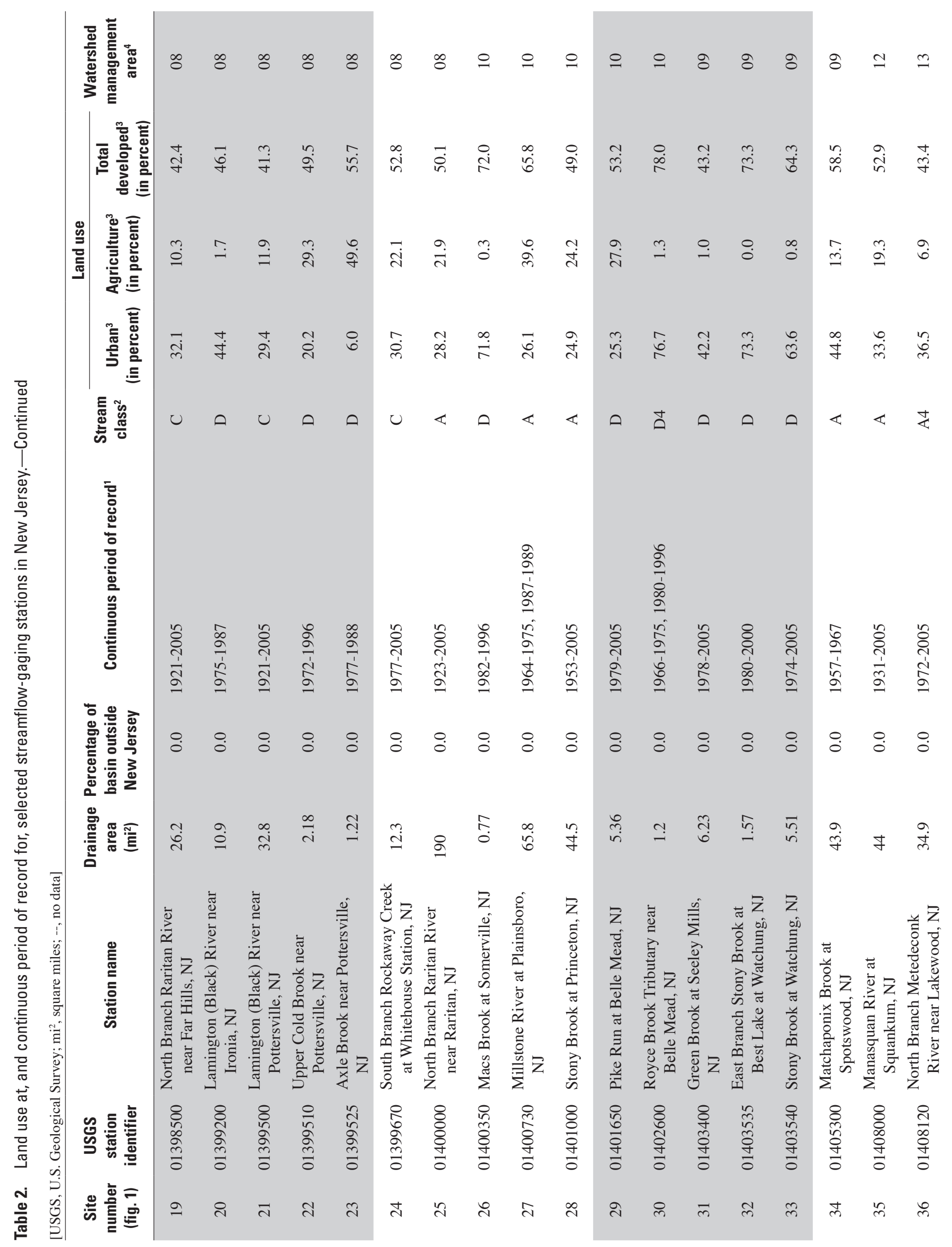




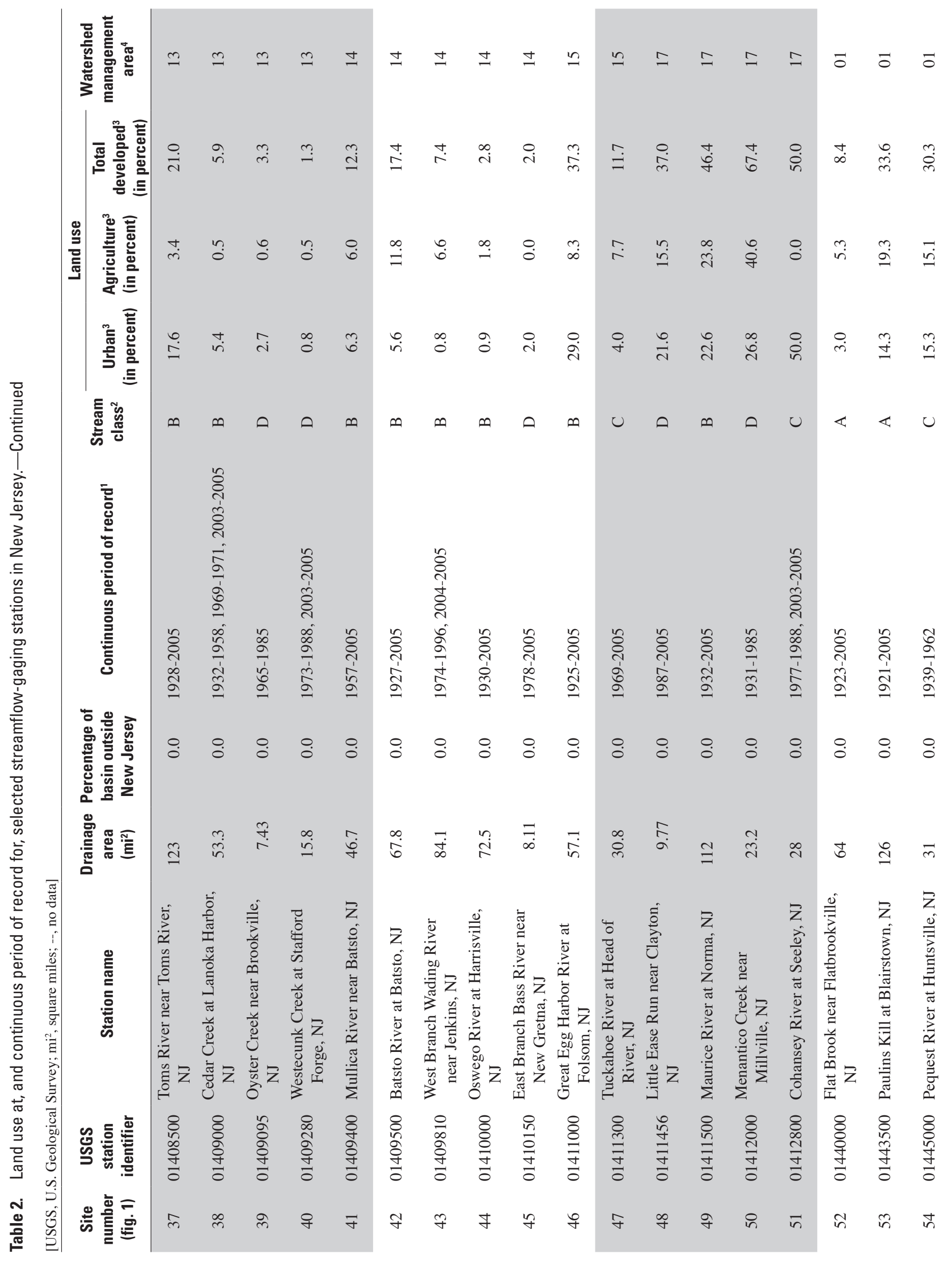




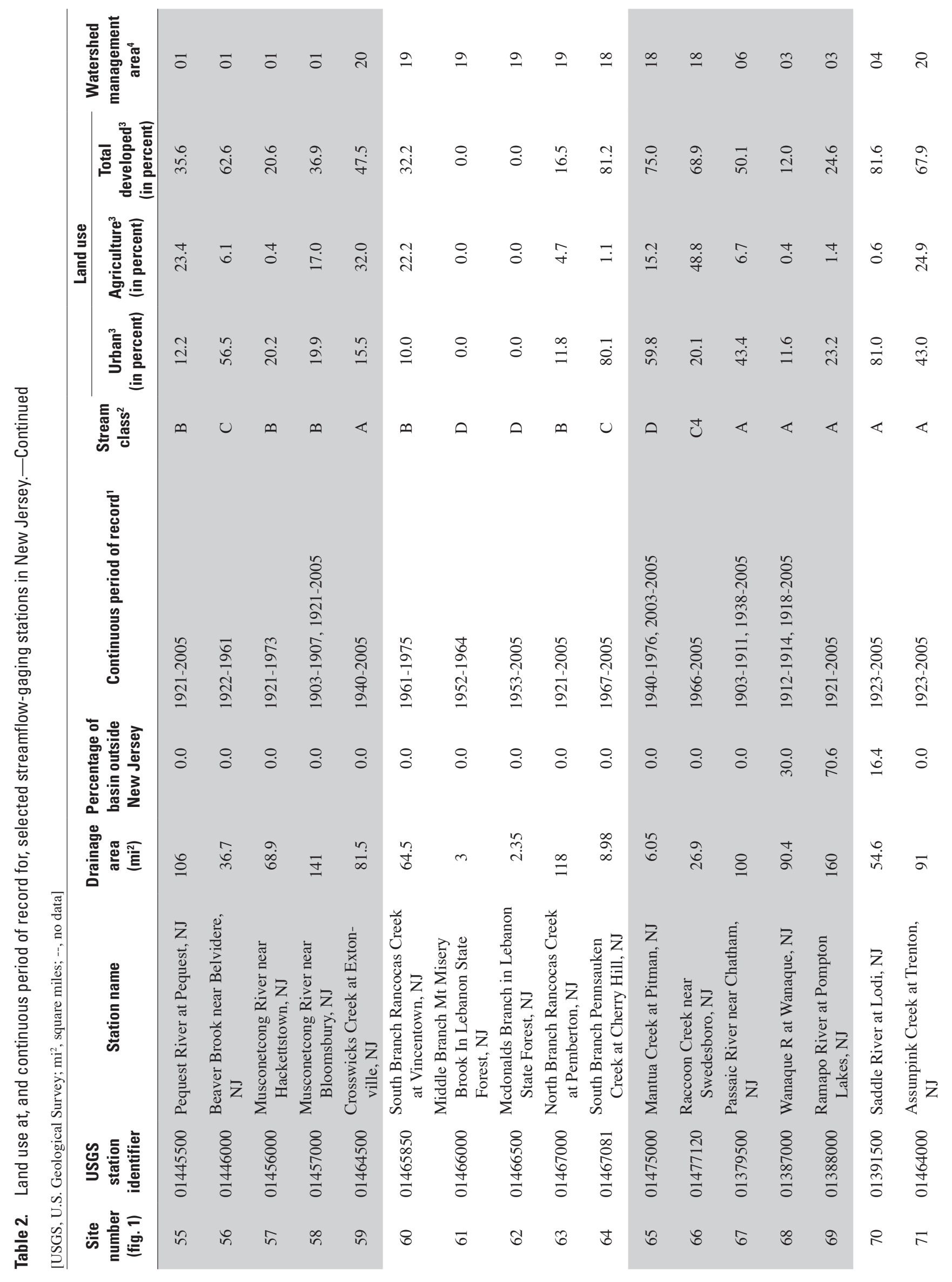




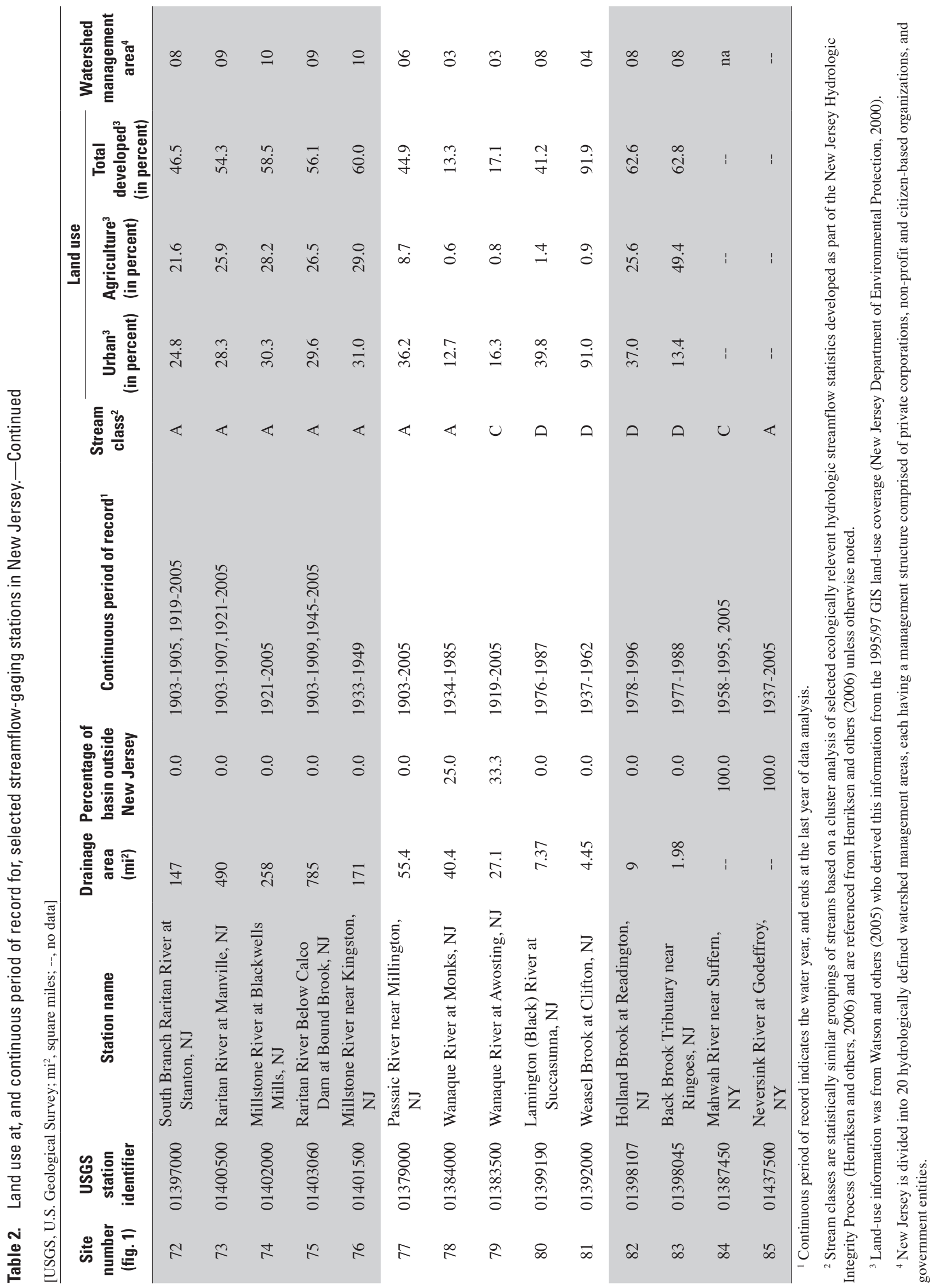


general climate divisions (division 1 or northern, division 2 or southern, and the near southern coastal area). In general, division 1 is the area north of the Fall Line, and division 2 occupies most of the area south of the Fall Line. The southern coastal area is that portion of the study area located south of the Fall Line that is proximal to the Atlantic coastline. Longterm average precipitation (1895-2002) for division 1 is 116.8 $\mathrm{cm}$, division 2 is $112.4 \mathrm{~cm}$, and the coastal area is $106.4 \mathrm{~cm}$. (Precipitation and temperature data are summarized on the basis of information from the Office of the New Jersey State Climatologist, 2007).

\section{Methods of Investigation}

This investigation was conducted in three steps. First, the minimum period of record required for calculating values of ERHIs for the four stream classes in New Jersey was determined. This process was based on statistical analysis of ERHIs for streams that are believed to have no substantial change in flow regime (index stations) and on previous investigations in which minimum periods of record were assigned (Henriksen and others, 2006). Because of the subjective nature of the process, a conservative approach was taken; a longer than necessary minimum period was selected rather than risk the possibility that the ERHIs would be dominated by temporary conditions such as droughts or wet periods.

In the second step, baseline periods were determined for each of the 85 streams. Historical records relating to streams and basins, and institutional knowledge of the hydrology of New Jersey, were examined. Historical land use was estimated for each basin to determine the least urbanized period of record for which continuous streamflow record was available, and a statistical approach was used to determine whether there were significant changes in streamflow characteristics based on annual streamflow data. For the statistical approach, the null hypothesis of no difference among the rate of increase in cumulative annual runoff and base flow relative to index streams was tested in order to confirm that no sudden and permanent changes in flow regime had occurred during the period being considered as baseline.

In the third step hydrologic index values were calculated for the 85 streams. The program NJHAT (Henriksen and others, 2006) was used, and values of 171 ERHI were calculated for each stream. All values of ERHIs for all streams will be listed in tabular form on the USGS World Wide Web site.

\section{Selection of Index Stations and Minimum Period of Record}

Streamflow data have been collected for streams in New Jersey over periods ranging from a few years to nearly a century. Shorter periods of record may coincide with aberrant weather and streamflow patterns that are not representative of typical conditions. Longer periods of record are more likely to provide a representative sample of central tendencies and variability of streamflow. Therefore, a minimum period of record was required for each stream class. Each of the four stream classes was assigned a minimum period of record, which is the least number of years of continuous record for which selected ERHIs maintain stable hydrologic conditions. These minimums were selected primarily by analyzing the variability of hydrologic indices calculated for seven index stations with drainage basins that have less than 15 percent urban development (table 3).

Index stations were selected on the basis of the criteria of Watson and others (2005) in which drainage basins with less than 15 percent urban development were considered undeveloped. Most streamflow-gaging stations in New Jersey that meet this criterion do not have a lengthy period of record. In order to include additional stations with sufficiently long periods of record, it was necessary to include one station (West Brook near Wanaque Reservoir) that has 17.7 percent urban development in the drainage basin. Two index stations each were selected for stream classes A, B, and C. Only one index station was selected for class D streams because no other index station of class D had a sufficiently long period of record.

Durations of 5 to 20 years were evaluated as possible minimum periods of record for the four stream classes. The entire period of record for each index stream was divided into non-overlapping sub-periods of 5, 10, 15, and 20 years. A range of percentile values $(5,10,20,30,40,50$ (median), 60, 70,80 , and 90) was calculated for selected hydrologic indices for each sub-period. For example, the index ML6 is defined as the median of June minimum flow values over the entire period of record. The remaining June minimum flows compose a frequency distribution of values for which a percentile $(5,10,20, \ldots)$ was calculated. Thus, a distribution was determined for each selected hydrologic index for each sub-period of record. The program NJHAT was used to calculate a range of values for selected ERHIs for each index station. From the initial 171 from previous analysis using the NJHIP, 10 ERHIs (one for each subcomponent of flow) were selected. These ERHIs were determined to be statistically significant and non-redundant for each stream class. Not all of the 10 indices were used for this analysis. In order to develop a meaningful percentile distribution for index values, those indices that were considered to be spatial were not included because calculation of these indices would result in a single value for which a distribution cannot be determined. The indices used for determining minimum periods of record are described in table 4.

For each index station and selected ERHI, the distribution of values was compared for each consecutive non-overlapping 5-year period over the entire period of record using the Kruskal-Wallis test. This test was repeated for 10-, 15-, and 20 -year periods. The null hypothesis specified no difference in the distributions of index values among sub-periods for a given index at each station. A p-value was calculated from the Kruskal Wallis test, which presents the probability that there is a difference in ERHI values between the sub-periods 


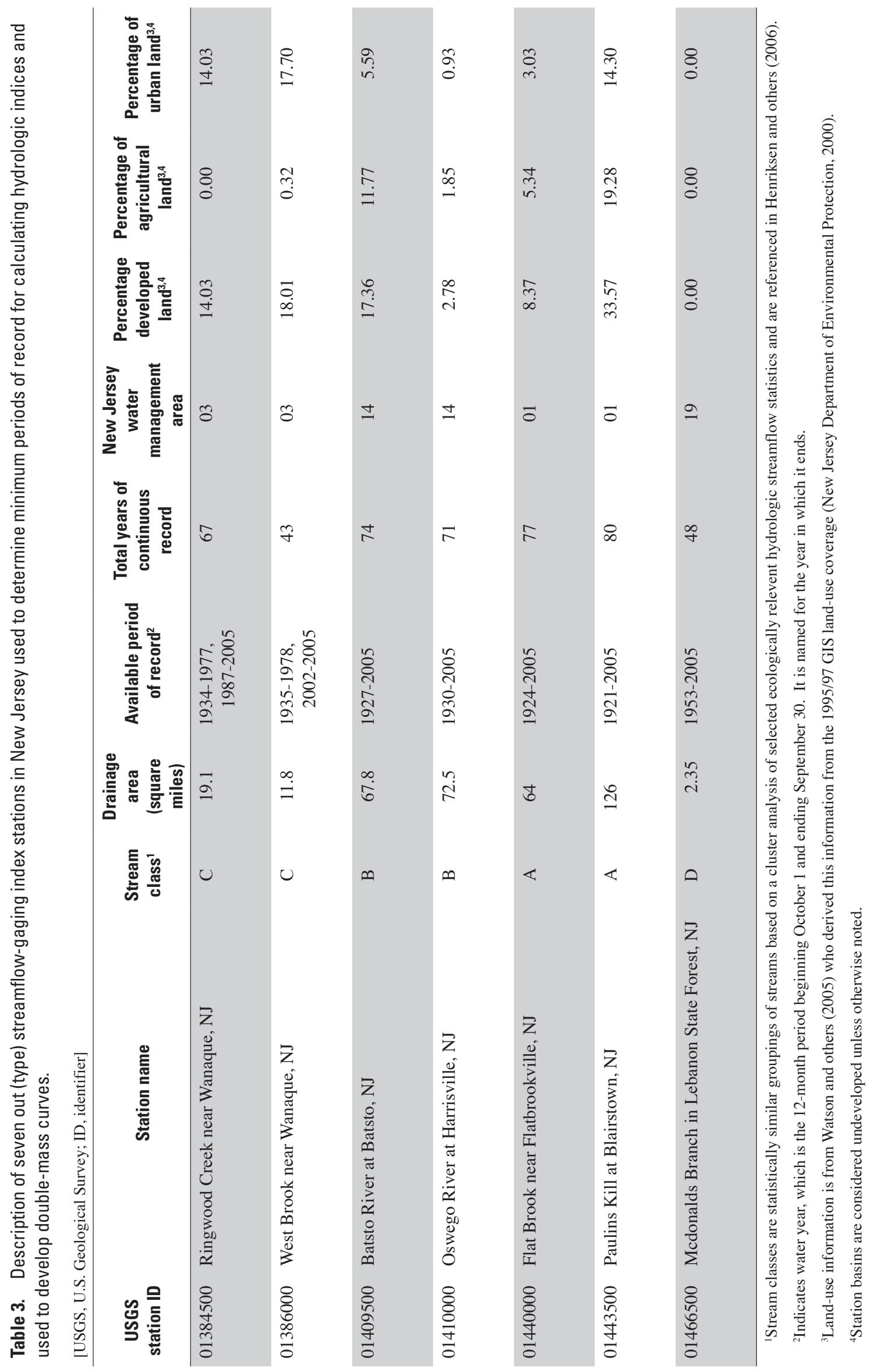




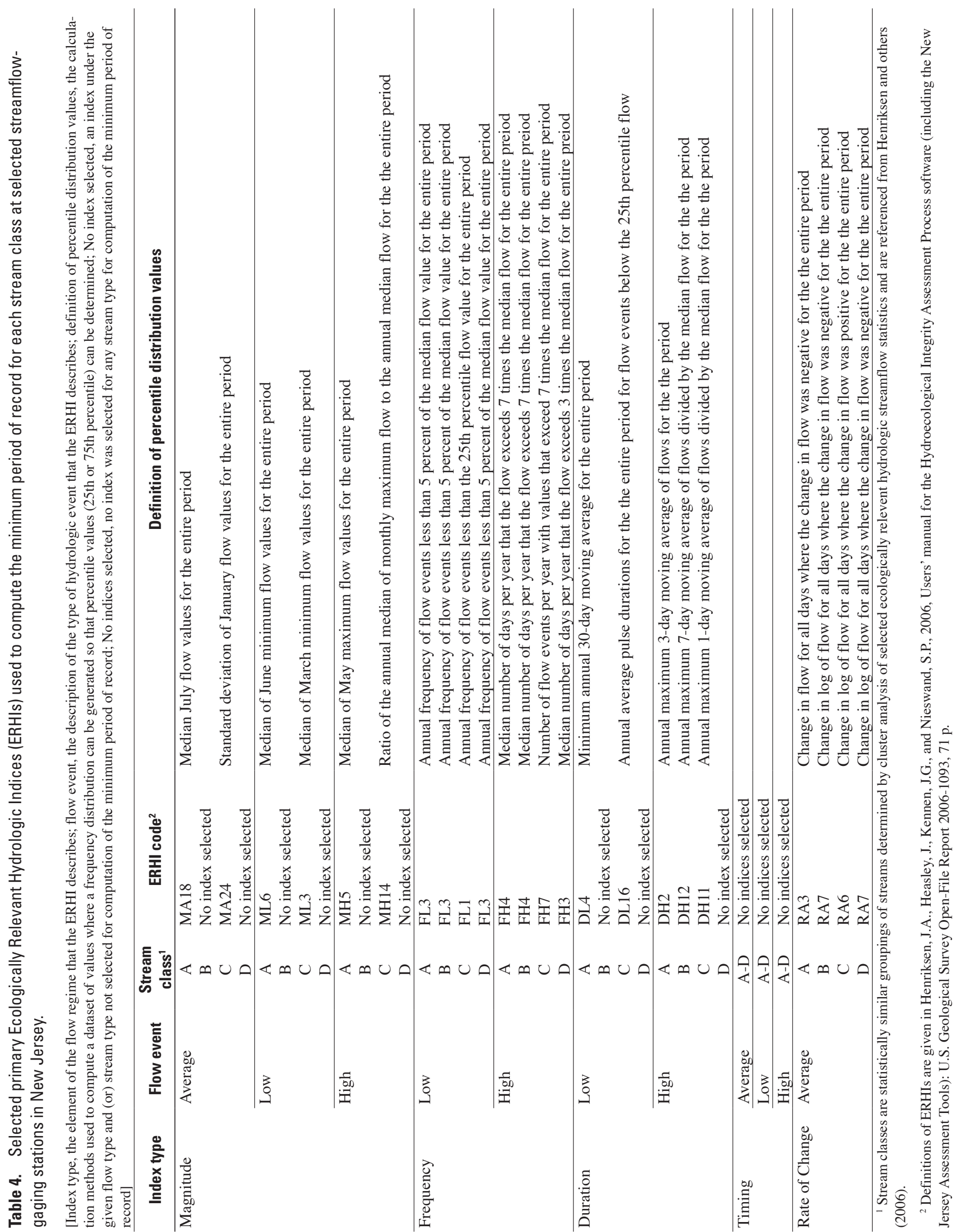


of record, with the critical p-value set at 0.05 . The minimum period of record for each stream class was defined as the shortest duration for which the null hypothesis was not rejected for all of the ERHIs tested. If the null hypothesis was rejected for any index for all groups of years, 20 years was accepted as the minimum period of record for that stream class. For stream classes $\mathrm{A}, \mathrm{B}$, and $\mathrm{C}$, the procedure was done for each of the two index stations, and the longer of the two minimum periods of record was selected for each stream class.

\section{Baseline Periods of Record for Selected Streams in New Jersey}

Calculation of hydrologic indices for baseline periods requires streamflow data from a continuous range of years during which the stream and the drainage basin were least altered by human activities. Changes such as regulation, landscape alteration, and surface-water and ground-water withdrawals in the drainage basin can affect streamflow characteristics and hydrologic indices.

For streams in relatively undeveloped and unregulated basins, the baseline period of record may include the entire period of record. For streams in highly developed basins, substantial human alteration and degraded ecological conditions can occur during many years of the period of record. For such streams, a range of years during which the level of development remained relatively constant can be used as the baseline period.

A baseline period of record was assigned for each stream on the basis of three criteria: (1) historical stream and basin information, (2) measured and estimated impervious surface in the drainage basin, and (3) statistically significant changes in annual runoff and base-flow volumes as determined with double-mass-curve analysis. Each baseline period of record was then compared to the minimum period of record determined for the appropriate stream class to determine whether the station had a sufficiently long record to generate meaningful ERHIs.

\section{Use of Historical Stream and Basin Information to Eliminate Non-Baseline Years and Define Preliminary Baseline Periods}

The preliminary baseline period of record is the continuous time period that remained after eliminating years that are clearly not baseline as determined from historical basin information. Historical information about each station was obtained from Annual Data Reports published each year by the USGS, New Jersey Water Science Center (Bauersfeld and others, 1983-95; Centarino and others, 2005; Reed and others, 1996-2004; U.S. Geological Survey, 1936-82; White and others, 2006) and from information provided by the staff at the USGS New Jersey Water Science Center (written and oral commun., 2007). All information related to stream regula- tion, sewage-effluent discharge, water withdrawal, and other information pertinent to the stream and drainage basin was considered. A preliminary baseline period was determined for each stream as the period during which the stream was least regulated or did not have any known major ground-water withdrawals or surface-water withdrawals or diversions affecting the drainage basin. For example, flows from the Ramapo River at Pompton Lakes have been diverted into the Wanaque Reservoir since 1953 (Centenary and others, 2004). Therefore, the preliminary baseline period is the beginning of the period of record (1921) to 1953.

\section{Use of Impervious Surface to Eliminate Non- Baseline Years}

Impervious-surface data were used to assess when substantial development had occurred in a basin, and to define the end of the baseline period. Where impervious surface data were not available, impervious surface was estimated from population density, land use, and other factors. Percentages of impervious surface and land use for drainage areas entirely within New Jersey were derived from geographic information system (GIS) coverages developed from 1986 and 1995-97 digital infrared aerial photos (New Jersey. Department of Environmental Protection, 2000) through use of the Anderson method of classification. This coverage divides land into a series of geographical areas (or GIS polygons) that are each assigned a single land-use classification, including Level I and Level II classifications in the Anderson system (Anderson and others, 1976). Level I classification consists of major categories, including, but not limited to, agricultural, urban, wetland, forested, barren, and water. Level II categories are more specific subcategories within Level I categories and include, for example, low- or high-density residential, deciduous or coniferous forest, or forested or unforested wetland.

For each station, a 30-meter-grid digital elevation coverage of New Jersey was used to create the basin boundary. A 1995/97 land-use coverage, which includes information about land-use changes from 1986, was overlaid on the basin coverage. The 1995-97 land-use data also includes estimates of impervious surface for each land-use polygon (fig. 2). Land-use data for the basins draining into Mahwah River near Suffern, N.Y. (01387450), and Neversink River at Godeffroy, N.Y. (01437500), were not included in this analysis because the data for New York State watersheds were not available at the time of the investigation. The size of each basin and the size of land-use areas within each basin were used to estimate the percentages of agricultural, urban, and undeveloped land, and to estimate the percentage of impervious surface. Percentages of each land-use type were calculated as the sum of the areas of that land-use type divided by the total area of the basin. At the time of this investigation (2006-07), land-use data were not available for areas outside of New Jersey. The drainage basins of eight stations encompass areas outside of New Jersey, and of those stations, five stations have drainage 


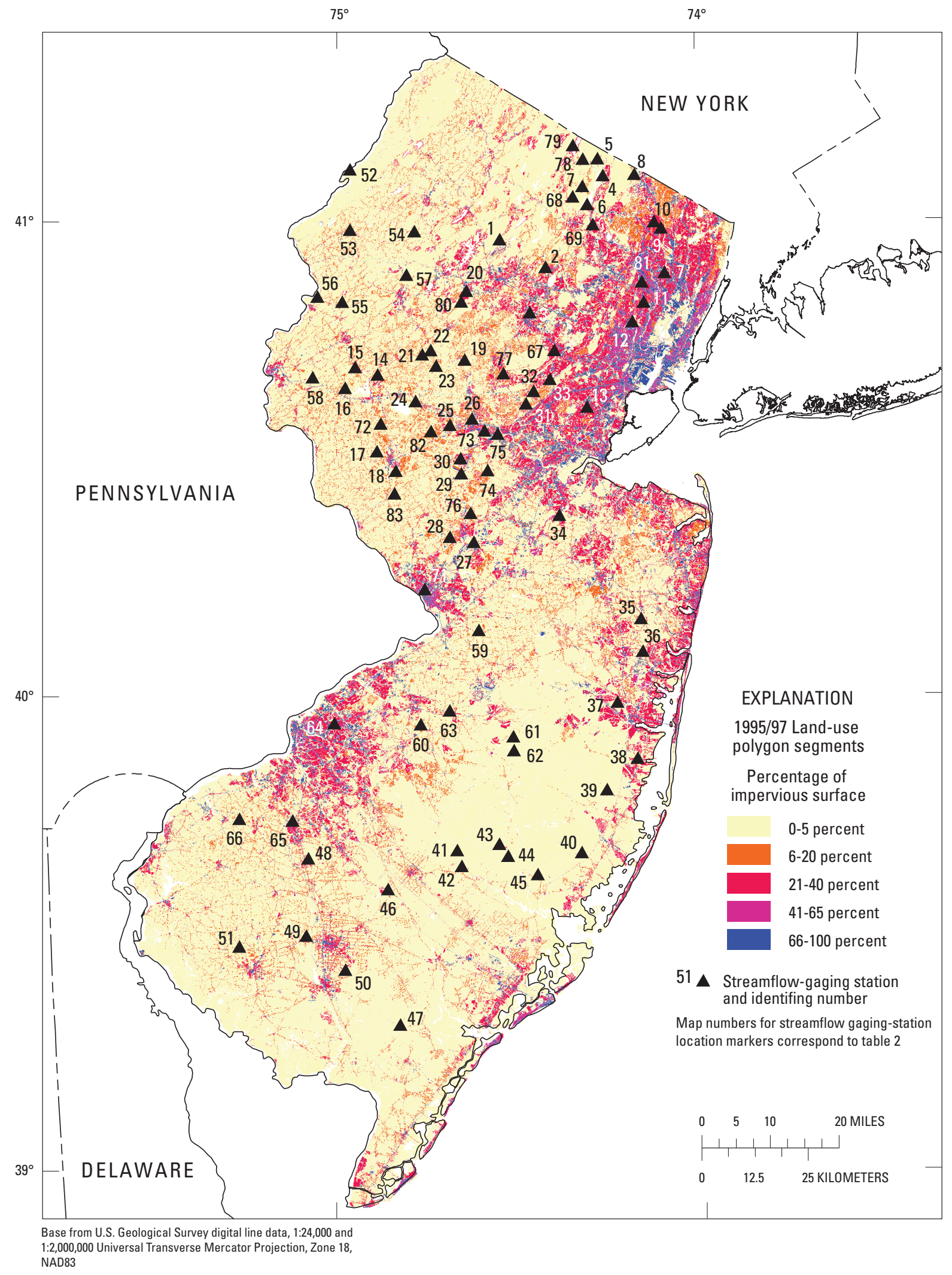

Figure 2. Impervious surface from the 1995/97 land-use coverage for all land-use polygon segments and locations of selected streamflow-gaging stations in New Jersey. (Data from New Jersey Department of Environmental Protection, 2000.) 
areas in which more than 50 percent of the basin is in New Jersey. For these stations, the percentage of the basin outside of New Jersey is listed in table 2. The percentages of land use and impervious surface in those basins were calculated by assuming that the percentage of a land-use type in the New Jersey portion of the basin was uniform throughout the entire basin. For the purposes of this investigation it was decided that any error introduced by using this assumption was acceptable because only 8 of the 85 stations were affected.

Impervious surface was not reported in the 1986 land-use survey; therefore, a method of estimating impervious surface from land-use data was developed. For each polygon of the GIS land-use coverage that did not change between the 1986 and 1995/97 coverages, the percentage of impervious surface was assumed to have remained constant. For polygons where the percentages of land use changed, the mean percentage of impervious surface for each Anderson Level II land use represented by the polygon in the 1995/97 land-use coverages was assigned to the 1986 land-use polygons. A list of the mean percentages of impervious surface and standard deviations for all Level II land uses in the New Jersey 1995/97 land-use coverage are listed in table 5. For the 1986 coverage, the fraction of impervious surface of the basin was the sum of impervious surface of each polygon multiplied by the fraction of the basin occupied by that polygon.

For years prior to 1986, only limited land-use and impervious-surface data are available. A 1973 land-use coverage is available (Anderson and others, 1976), but this coverage lacks sufficient Level II land-use data for estimating impervious surface. Therefore, the 1995/97 population-density data from the United States Census Bureau (2007) were used to relate population density to impervious surface, and this relation was used to estimate impervious surface for years that population density data were available. This method is similar to that developed by Stankowski (1972), where population-density data for 570 municipalities were used to estimate impervioussurface data (based on State of New Jersey surveyed land-use data). It was assumed that the relation of impervious surface to population density for municipalities was more strongly correlated than the relation of impervious surface to population density for drainage basins because municipality boundaries contain more homogeneous community structures than are indicated by the land-use patterns within drainage-basin boundaries.

A GIS coverage was created that contained census data, area, and population density for 570 municipalities for 10-year intervals (1930-2000). Population data for each municipality were obtained from historic U.S. Census Bureau archives (United States Census Bureau, 2007). Population density was computed for each municipality by dividing the municipality area by the total population from the census data. Land-use and impervious-surface data for municipalities also were obtained from the 1995/97 GIS coverage in order to correlate impervious surface to population density from the New Jersey municipality GIS coverage. The1995/97 land-use coverage was overlaid on the municipality coverage. The area of the municipality and the area of each land-use type within the municipality were used to compute the land-use percentages for each municipality. The percentage of impervious surface in relation to population density for all municipalities in New Jersey is shown in figure 3 . The relation developed by Stankowski (1972) also is shown. A relation (Equation 1) was developed between impervious surface in 1996 and population density using the interpolated population-density information and impervious-surface percentages for municipalities. This regression was developed using a third-order polynomial least-squares regression of the log of values of population density, and predicts an increase in the percentage of impervious surface as a function of increasing population density for population densities between 0 and about 14,000 persons per square mile. The coefficient of determination $\left(\mathrm{r}^{2}\right)$ is 0.91 .

The relation then was expressed in terms of the impervious surface variable:

$$
I E=10^{\left(\left(0.26-(1.2(\log P))+\left(0.83(\log P)^{2}\right)-11(\log P)^{3}\right)\right.}
$$

where,

$$
\begin{aligned}
I E= & \text { estimated percentage impervious surface } \\
& \text { and } \\
P \quad= & \text { population density, in people per square } \\
& \text { mile. }
\end{aligned}
$$

The municipality coverage was overlaid on the basin polygon for each gaging station. The area of the basin and the area of each municipality within the basin were used to compute the population density for the basin. Population density for those basins with drainage areas not completely included in New Jersey was estimated by assuming that the population density in the New Jersey portion of the basin represented the density of the entire basin. Population densities for 1986 and 1996 were estimated by linear interpolation of the population densities between 1980 and 1990, and 1990 and 2000, respectively. Using population-density data for each drainage basin, equation 1 was used to estimate percentages of impervious surface.

Not all types of urban development result in increased population density or predictable amounts of impervious surface. For example, according to the 1995/97 Land-use GIS coverage, the impervious surface for Teterboro Borough in Bergen County was 56.0 percent, and the population density was 16.8 people per square mile (United States Census Bureau, 1996). For Cliffside Park Borough, also in Bergen County, the impervious surface was 56.8 percent of the municipality with a population density of 23,486 people per square mile. The large difference in population densities are due to the Teterboro Airport located in the boroughs of Teterboro and Moonachie. The airport covers an area of 1.3 square miles and accounts for 47 percent of the combined area of Teterboro Borough and Moonachie Borough. An airport would have little to no population density but extensive amounts of impervious surface. In order to improve the relation between population density and impervious surface, a correction factor was 
Table 5. Means and standard deviations of the percentages of impervious surface for each Type II land use for each polygon segment from the 1995/97 land-use coverage of New Jersey'.

$[>$, greater than; <, less than; \%, percent $]$

\begin{tabular}{|c|c|c|c|}
\hline $\begin{array}{l}\text { Type I } \\
\text { land-use for } \\
\text { polygons }\end{array}$ & Type II land use for polygons & $\begin{array}{l}\text { Mean percentage } \\
\text { of impervious } \\
\text { surface for all polygons }\end{array}$ & $\begin{array}{l}\text { Standard deviation of the } \\
\text { percentage of impervious } \\
\text { surface for all polygons }\end{array}$ \\
\hline & Recreational Land & 25.8 & 30.2 \\
\hline & Residential, High Density, Multiple Dwelling & 57.2 & 15.2 \\
\hline & Residential, Rural, Single Unit & 13.3 & 4.0 \\
\hline & Residential, Single Unit, Low Density & 21.6 & 2.9 \\
\hline & Residential, Single Unit, Medium Density & 32.0 & 2.9 \\
\hline & Transportation/Communications/Utilities & 39.8 & 36.0 \\
\hline \multirow[t]{4}{*}{ Water } & Artificial Lakes & 0.0 & 0.2 \\
\hline & Atlantic Ocean & 0.0 & 0.0 \\
\hline & Dredged Lagoon & 0.0 & 0.0 \\
\hline & Natural Lakes & 0.0 & 0.0 \\
\hline \multirow[t]{21}{*}{ Wetlands } & Agricultural Wetlands (Modified) & 0.0 & 0.5 \\
\hline & Atlantic White Cedar Swamp & 0.0 & 0.3 \\
\hline & Coniferous Scrub/Shrub Wetlands & 0.0 & 0.2 \\
\hline & Coniferous Wooded Wetlands & 0.0 & 0.3 \\
\hline & Deciduous Scrub/Shrub Wetlands & 0.0 & 0.3 \\
\hline & Deciduous Wooded Wetlands & 0.0 & 0.6 \\
\hline & Disturbed Wetlands (Modified) & 1.0 & 4.1 \\
\hline & Former Agricultural Wetland (Becoming Shrubby, Not Built-Up) & 0.1 & 0.8 \\
\hline & Freshwater Tidal Marshes & 0.0 & 0.4 \\
\hline & Herbaceous Wetlands & 0.0 & 0.4 \\
\hline & Managed Wetland In Built-Up Maintained Recreation Area & 2.1 & 7.1 \\
\hline & Managed Wetland In Maintained Lawn Greenspace & 1.7 & 4.0 \\
\hline & Mixed Forested Wetlands (Coniferous Dom.) & 0.0 & 0.6 \\
\hline & Mixed Forested Wetlands (Deciduous Dom.) & 0.0 & 0.3 \\
\hline & Mixed Scrub/Shrub Wetlands (Coniferous Dom.) & 0.0 & 0.0 \\
\hline & Mixed Scrub/Shrub Wetlands (Deciduous Dom.) & 0.0 & 0.2 \\
\hline & Mixed Srcub/Shrub Wetlands (Coniferous Dom.) & 0.0 & 0.0 \\
\hline & Saline Marshes & 0.0 & 0.3 \\
\hline & Severe Burned Wetlands & 0.0 & 0.0 \\
\hline & Vegetated Dune Communities & 0.2 & 1.2 \\
\hline & Wetland Rights-Of-Way (Modified) & 0.4 & 3.7 \\
\hline
\end{tabular}

${ }^{1}$ New Jersey Department of Environmental Protection, 2000, 1995/97 Landuse/Landcover by Basin Management Area (WMA): Trenton, N.J., accessed March 15, 2006, at http://www.state.nj.us/dep/dsr/map-integration/LULC95.htm. 


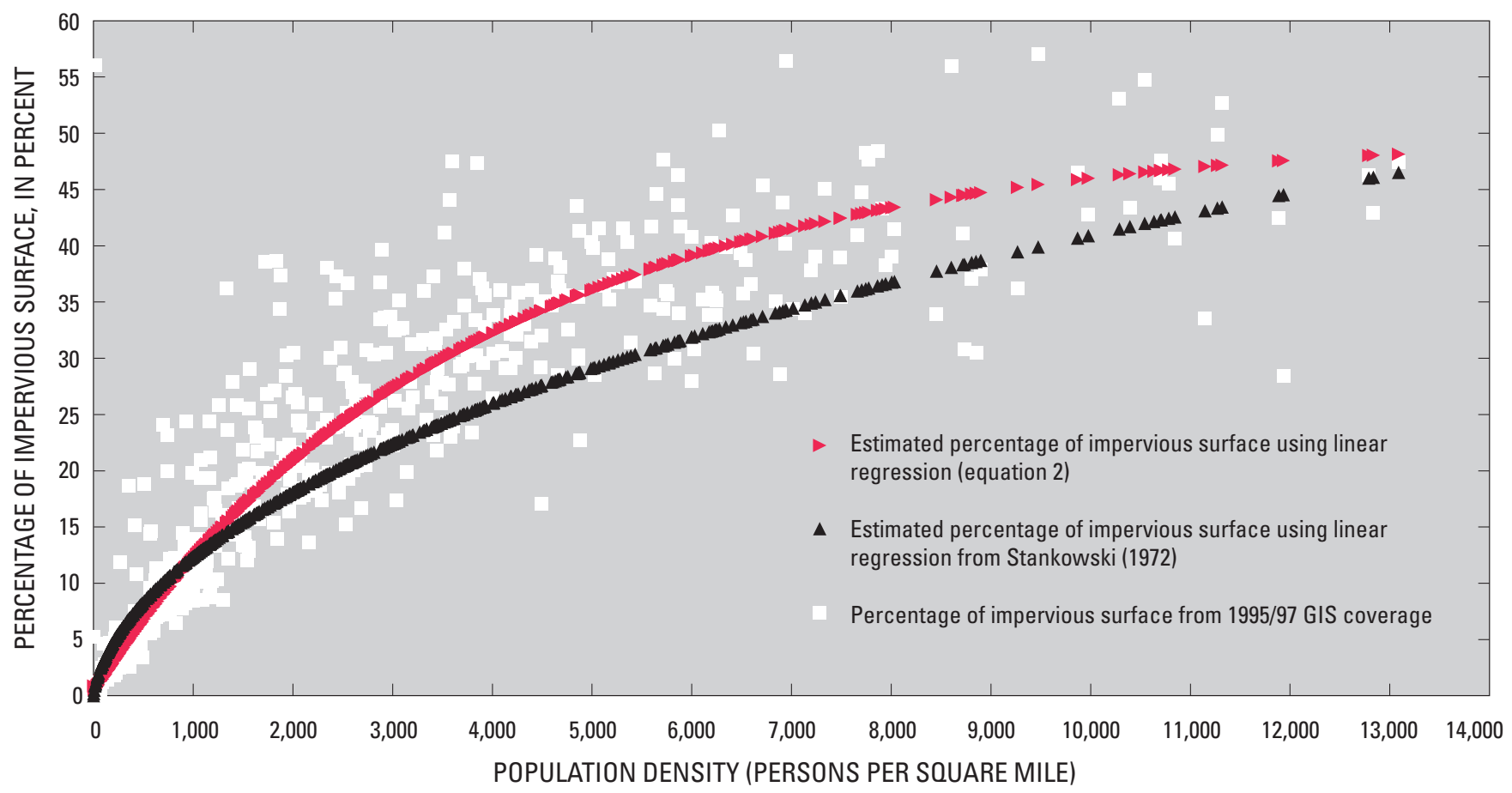

Figure 3. Relation of the percentage of impervious surface from 1995-1997 geographic information system (GIS) digital land-use information to population density in persons per square mile for all 570 municipalities in New Jersey.

(Impervious-surface data were derived from a digital geographic information system coverage of land use in New Jersey during 1995-1997 (New Jersey Department of Environmental Protection, 2000). Municipality and population density information are from U.S.

Census Bureau for the years 1930-2000 (U.S. Census Bureau, 2007).)

applied to equation 1 for each basin to account for the land use within drainage basins that are related to impervious surface but not to population density. The adjusted impervious surface estimate IA in equation 2 is a linear interpolation between the impervious surface estimated by population density from equation 1 and that estimated from 1986 and 1995 land use.

$$
I A=C^{*} I E,
$$

where

$$
\begin{aligned}
I A= & \text { estimated adjusted impervious surface } \\
& \text { percentage estimated, } \\
C \quad= & \text { correction factor, and } \\
I E \quad= & \text { estimated impervious surface percentage } \\
& \text { from equation } 1 .
\end{aligned}
$$

The correction factor, $\mathrm{C}$, is used to represent the percentage difference between the impervious surface estimated from population density in equation 1 and from the impervious surface from both the 1986 and 1995/97 land-use coverages. The percentage difference between impervious surface estimated from equation 2 and the impervious surface from the 1986 land-use coverages, and the percentage difference between estimated impervious surface and the 1995/97 land-use coverage, may not be consistent because the relation between population density and impervious surface may have changed between 1986 and 1996 as a result of the higher resolution of the later dataset or due to error inherent in the regression. To account for these differences, a simplified linear calculation of the correction was used to obtain one correction factor. In order to obtain one correction factor, the percentage differences for the two datasets were averaged (equation 3).

$$
C=\left(\left[\left(I E_{1986} /\left(I G_{1986}\right)\right]+\left[\left(I E_{1996} /\left(I G_{1995 / 997}\right]\right) / 2,\right.\right.\right.
$$

where

$$
\begin{array}{cc}
I E_{1986}= & \text { estimated impervious surface percentage } \\
& \text { from equation } 1 \text { for the estimated } \\
& \text { population density in } 1986 \text { using a linear } \\
& \text { interpolation of population density } \\
& \text { between the years } 1980 \text { and } 1990, \\
I E_{1995 / 97}= & \text { estimated impervious surface percentage } \\
& \text { from equation } 1 \text { for the estimated } \\
& \text { population density in } 1996 \text { using a linear } \\
& \text { interpolation of population density } \\
& \text { between the years } 1990 \text { and 2000, } \\
I G_{1986}= & \begin{array}{l}
\text { impervious surface percentage estimated } \\
\text { from the 1986 land-use coverage, and }
\end{array} \\
I G_{1995 / 97}= & \begin{array}{l}
\text { impervious surface percentage from the } \\
\end{array} \\
& 1995 / 97 \text { land-use coverage. }
\end{array}
$$


Values for IA were calculated by linear interpolation for each selected station for every 10 years from 1930 to 2000 and for every year between decades.

Percentages and changes in impervious surface were then used to help determine baseline periods. Four thresholds of increasing impervious surface were defined:

- Less than 10 percent impervious surface,

- Greater than 10 percent and less than 20 percent impervious surface,

- Greater than 20 percent and less than 15 percent increase in impervious surface, and

- Greater than 20 percent and greater than 15 percent increase in impervious surface.

Ideally, a baseline period would not cross an impervioussurface threshold, indicating a relatively stable percentage of impervious surface during the baseline period. For example, the basin of station 1387500 (Ramapo River at Mahwah, NJ) had less than 10 percent impervious surface in the first year of continuous hydrologic record (1923) The first threshold (greater than 10 percent and less than 20 percent) was not crossed until 1964. This period of 41 years exceeds the minimum baseline period of the station's stream class (class A, 20 years); therefore, the preliminary baseline period was ended at 1964. If the threshold had been reached before the minimum baseline period of record, then additional years of record would have been added until the next threshold was reached. If the minimum period was still not achieved, additional years would be added up to the next threshold, and so on.

The percentage of impervious surface in the drainage basin upstream from each streamflow-gaging station was used to evaluate the quality of the baseline period. A basin having less than 10 percent impervious surface is ranked "excellent," 10 to 20 percent impervious surface with less than 15 percent increase is ranked "good," greater than 20 percent impervious surface with less than 15 percent increase is ranked "fair," and greater than 20 percent impervious surface with greater than 15 percent increase is ranked "poor." A summary of this rating scale is shown in table 6 . Results from double-mass analysis (next section) were combined with these rankings to assign final baseline periods and overall baseline-period-quality.

\section{Double-Mass-Curve Analysis}

Analysis of covariance of double-mass curves (Searcy and Hardison, 1960) was used as an additional tool for determining baseline periods of record for the 85 gaging stations. A double-mass curve is a linear plot of the cumulative value of one variable as a function of the cumulative value of a second variable. Here, the variables are streamflow at two locations, a test station (x-axis) and an index station (y-axis). Baseline conditions are assumed for the index station for the period of record being tested. An abrupt change in the slope of the double-mass curve, referred to as a "breakpoint," indicates
Table 6. Baseline period-of-record quality classification based on estimated impervious surface in selected drainage basins in New Jersey.

$[<$, less than; $>$, greater than $]$

\begin{tabular}{ccl}
\hline $\begin{array}{c}\text { Estimated } \\
\text { impervious surface } \\
\text { (in percent) }\end{array}$ & $\begin{array}{c}\text { Estimated increase in } \\
\text { impervious surface } \\
\text { (in percent) }\end{array}$ & $\begin{array}{c}\text { Baseline quality } \\
\text { ranking }\end{array}$ \\
\hline$<10$ & $<10$ & Excellent \\
$10-20$ & $<15$ & Good \\
$>20$ & $<15$ & Fair \\
$>20$ & $>15$ & Poor \\
\hline
\end{tabular}

a change in hydrologic conditions at the test station and can be interpreted as the end of the baseline period for that test station. A straight line without breakpoints indicates that the period of record being tested for the test station can be considered "baseline" with respect to the double-mass analysis. The assumption is made that climatological variables will have similar effects on the index station and the test station, and that a breakpoint in the double-mass curve indicates a hydrological change only in the test stream. Double-mass curves were prepared separately for runoff and base-flow data.

Annual total runoff and annual total base flow were calculated by using the HYSEP (Hydrograph Separation) program (Sloto and Crouse, 1996). The method used for hydrograph separation was the Local-Minimum Method (LMM) (Pettyjohn and Henning, 1979). For the three stream classes that are each associated with two index stations, both index stations were subjected to double-mass analysis. The fourth stream class is associated with only one index station.

\section{Analysis of Covariance of the Double-Mass Curve}

Analysis of covariance was used to test the significance of potential breakpoints on each double-mass curve, as described by Searcy and Hardison (1960). In this method, a variance-ratio test (or "F-test") (Snedecor, 1934) is used to determine the probability (p) that the null hypothesis of no difference between slopes of the line segments before and after the breakpoint can be rejected with a critical value of $\mathrm{p}=0.05$.

The F-test is sensitive to the variability (scatter) of points in each of the two line segments. Since the F-test compares the variability between periods to variability within periods, comparing line segments with high coefficients of determination $\left(r^{2}\right)$ may lead to the designation of a minor inflection in slope as significant. For example, a double-mass curve for runoff and base flow for Ringwood Creek near Wanaque as a test station and West Brook near Wanaque as an index station is shown in figure 4 . Because both sites are stream class $C$ index stations, a double-mass curve should not have any breakpoints; however, several minor breakpoints were detected. 


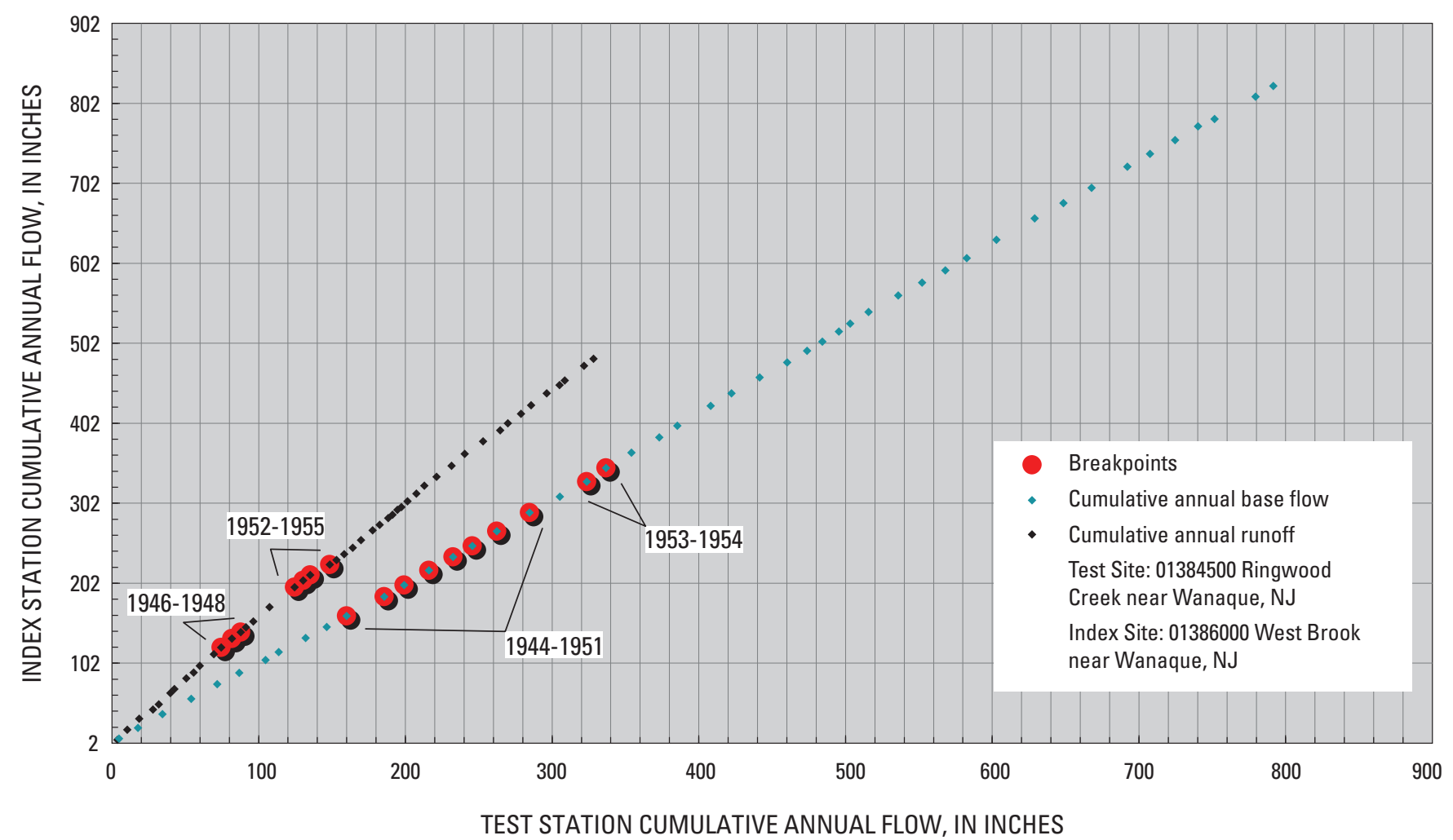

Figure 4. Example of double-mass curves for cumulative annual runoff and base flow at sites with low variability of annual values for selected streamflow gaging stations in New Jersey.

(Breakpoints are changes in the slope of the relation between streamflow at the index station and streamflow at the test station.)

Although the deflection of the slope (quantified by the ratio of regression-line slope before the breakpoint to that after the breakpoint) is statistically significant, these breakpoints do not appear to represent real changes in streamflow. Therefore, in addition to significance as determined by analysis of covariance, slope ratios and visual inspection of double-mass curves were used to determine whether substantial changes in streamflow occurred in years where a breakpoint is identified on a double-mass curve.

Searcy and Hardison (1960) recommend applying the analysis of covariance test only after visually inspecting the double-mass curve to identify possible breakpoints. For this investigation, it was decided that in doing so one might overlook minor breakpoints and identify only the breakpoints that are most apparent visually. Therefore, all points on each double-mass curve were tested as potential breakpoints, and slopes of the line segments before and after each point were compared. This facilitated the interpretation of breakpoints that are not apparent visually as single points but occur as gradual changes in slope, which may occur where land-use changes are gradually altering streamflow characteristics.

\section{Interpretation of Double-Mass Curves}

Two double-mass curves were prepared for each stream, one for annual cumulative runoff and the other for annual cumulative base flow. Only test stations that had at least 10 years of record in common with the appropriate index station were subjected to double-mass-curve analysis.

For each double-mass curve, all years in which the analysis-of-covariance critical F-value ( $\mathrm{p}=0.05$ significance level) was exceeded were identified as possible breakpoints. Additional possible breakpoints were identified by visual inspection of double-mass curves. A method of assessing overall breakpoint quality was devised, where the criteria were breakpoint appearance, breakpoint prominence, and slope ratio.

Breakpoint appearance is a numerical scale based on a visual assessment of whether the change in streamflow at the test station relative to that of the index station was abrupt or gradual, and of the severity of inflection. A single, distinct breakpoint can indicate a substantial change in the basin, such as regulation of a stream leading to immediate increases in discharge during low flow or decreases during peak flow. A slight but gradual inflection at the breakpoint, often accompanied by other significant breakpoints of lower inflection, could indicate a gradual change in the basin, such as a slowly increasing 
percentage of urban land use leading to a gradual increase in runoff and decrease in base flow. Breakpoint appearance scores were assigned as follows:

- Breakpoint-appearance score of 5: Inflection is strongly distinct and associated with a single breakpoint,

- Breakpoint-appearance score of 4: Inflection is moderately distinct and associated with a single breakpoint,

- Breakpoint-appearance score of 3: Inflection is moderately distinct and associated with more than one breakpoint,

- Breakpoint-appearance score of 2: Inflection is slight but distinct and associated with a single breakpoint,

- Breakpoint-appearance score of 1: Inflection is slight and gradual or curved, and

- Breakpoint-appearance score of 0: No inflection is visible.

Breakpoint prominence is a numeric scale used to assess the strength of each breakpoint relative to other breakpoints on the same double-mass curve. Where more than one significant breakpoint is present, this scale is used to decide when the most substantial change in hydrological conditions occurred at the test station and to assign the beginning or end of the baseline period. Breakpoint-prominence scores were assigned as follows:

- Breakpoint prominence score of 4: Breakpoint has the highest F-values and is the most visually prominent breakpoint on the double-mass curve;

- Breakpoint-prominence score of 3: Breakpoint has the highest F-values but is not the most visually prominent breakpoint on the double-mass curve, or breakpoint does not have the highest F-value but is the most visually prominent;

- Breakpoint-prominence score of 2: Breakpoint does not have the highest F-value and was not the most visually prominent breakpoint on the double-mass curve, or breakpoint has the highest F-value, but the correlation between the cumulative discharge at the index station and the test station was weak; and

- Breakpoint-prominence score of 1: Any additional breakpoints identified by visual inspection or by analysis-of-covariance hypothesis testing that are less prominent than a breakpoint that has a score of 2 .

Breakpoint-slope ratio is defined as the slope of the regression line after the breakpoint, divided by the slope of the regression line before the breakpoint. A slope ratio of greater than 1 indicates a decrease in flow relative to the flow at the index station; a slope ratio of less than 1 indicates an increase in flow. The slope ratio is an indication of the magnitude of a breakpoint. A rating system of slope ratios was devised, where
- Breakpoint-slope ratios score of 1: Slope ratio 0.9-1.1,

- Breakpoint-slope ratios score of 2: Slope ratio 0.7-0.9 and 1.1-1.3,

- Breakpoint-slope ratios score of 3: Slope ratio 0.5-0.7 and 1.3-1.5, and

- Breakpoint-slope ratios score of 4: Slope ratio less than 0.5 or greater than 1.5 .

The three criteria (breakpoint appearance, breakpoint prominence, and slope ratio) were used with Equation 4 to calculate an overall breakpoint rating for each breakpoint:

$$
B R=(B A / B P+S R / B P)
$$

where

$$
\begin{aligned}
B R= & \text { breakpoint rating, the final weighted score } \\
& \text { used to determine the relative strength of } \\
& \text { the breakpoint on the double-mass curve, } \\
B= & \text { score for breakpoint appearance, } \\
B P= & \text { score for breakpoint prominence, and } \\
S R= & \text { score for slope ratio. }
\end{aligned}
$$

A breakpoint rating of 0 to 8 indicates that the apparent breakpoint was not significant, a value of 9 to 15 indicates a weak breakpoint, a value of 16 to 22 is considered a moderate breakpoint, a value of 22 to 32 is considered a strong breakpoint, and a value greater than 32 is considered very strong.

\section{Baseline Period of Record Determination from Double-Mass Analysis}

The year in which the earliest substantial breakpoint was identified was considered the end of the baseline period if the minimum period of record was equaled or exceeded. Typically, the earlier period before a significant breakpoint was considered the baseline period unless historical information or other evidence indicated that a later range of years should be used as the baseline period. If the minimum period of record included a year that was considered a significant breakpoint, the earliest minimum period of record was used as baseline, but the quality of the baseline period was rated as poor.

\section{Ranking the Baseline Period}

After the three baseline determination procedures were completed (historical information, land use, and double-mass analysis), results were combined to assign a baseline period of record for each station (figure 5). A ranking (excellent, good, fair, or poor) was then assigned to each baseline period.

Preliminary baseline periods were first determined by analyzing historical information for each station (step 1). Then all years that were considered baseline were analyzed further by evaluating historical land use (step 2) and by using analysis 


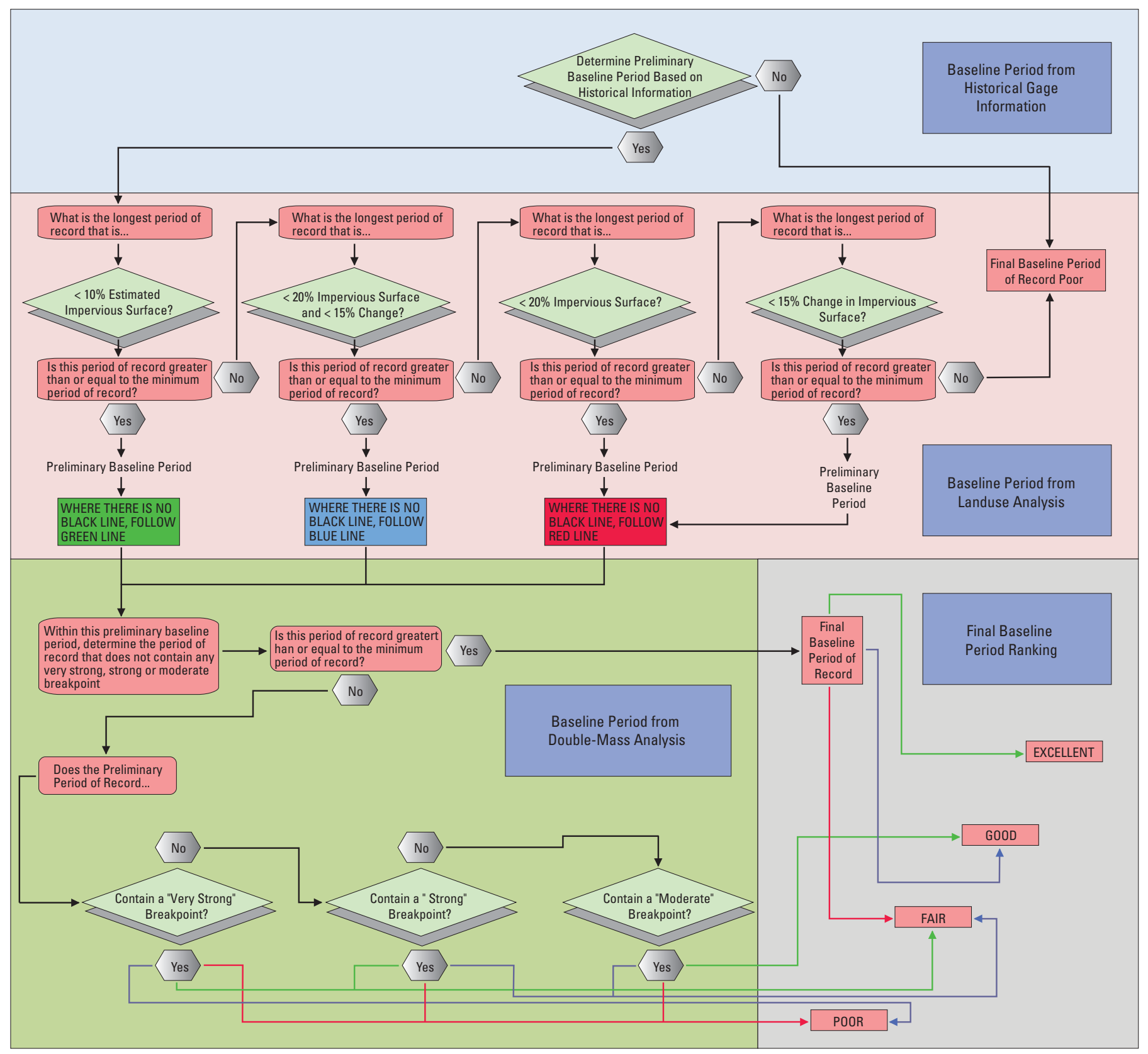

Figure 5. Flowchart showing the steps for determining baseline periods and the quality of baseline period.

of covariance of double-mass curves (step 3). If the preliminary baseline period determined in step 1 was less than the minimum period of record, it was categorized as poor.

For the latter two steps, the record was not reduced below the minimum period of record for any reason, but the quality of the baseline period was determined by how many impervious surface criteria thresholds were exceeded (10 percent, 20 percent, or a change in impervious surface that exceeds 15 percent since the start of the period of record) and how many breakpoints (weak, strong, or very strong) were evident within the minimum period of record.

\section{Determination of Baseline Period for 85 Selected Streamflow-Gaging Stations}

Baseline periods were quantified for each streamflowgaging station by determining the minimum period of record for the stream class that the station belongs to, analyzing the history of the station and its basin, and conducting a doublemass-curve analysis. 


\section{Minimum Period of Record}

Results from the Kruskall-Wallis test for 5-,10-, 15- and 20-year periods at the seven index sites with stream classes $\mathrm{A}, \mathrm{B}, \mathrm{C}$ and $\mathrm{D}$ are listed in table 7. For each index station, a Kruskall-Wallis p-value was calculated to test the null hypothesis of no difference among index values calculated for each 5-, 10-, 15- and 20-year increments of the period of record. The critical p-value was set at 0.05 . A conservative approach was taken in assigning the minimum period of record based on these results by selecting the sub-period with the least number of years in which the null hypothesis was accepted for all temporal hydrologic indices.

Based on these results, a minimum period of record of 10 years was applied for stations that are considered stream classes B or C, and a minimum period of record of 20 years was applied for stations that are considered stream classes A or D. For stream class B, the results indicate that there is no difference in the periods of record, but 10 years was selected as a minimum period of record owing to guidelines suggesting the minimum use of 10 years for all frequency and duration statistics (Hofmann, 1973), which are used to compute values of many ERHIs.

\section{Historical Analysis}

The preliminary historical baseline periods for 85 streamflow-gaging stations, with a general summary of the human alterations along the stream or in the drainage basin are presented in table 8. Details on historical flow for each station along with considerations in the determination of the historical baseline period are provided in appendix 1

\section{Land-Use/Land-Cover and Impervious Surface}

The percentages of Level I land use from the 1995/97 land-use coverage are listed in table 2 , and the estimated percentages of impervious surface from 1986 and 1995/97 land-use data are listed in table 9. The years in which the percentage of impervious surface was estimated to have exceeded thresholds (previously defined) are shown in table 10.

The estimated average population densities from 1930 to 2000 for the drainage basin areas of 83 stations are listed in table 11. For 22 of the 83 drainage basins, the impervious surface exceeded 10 percent of the area for part or all of the period of record. For 11 basins, the value exceeded 20 percent.

In order to estimate the year that the percentage of impervious surface changed by 15 percent from the first year of the continuous period of record for stations where the period of record started before 1930, the exponential relation between population density and impervious surface (figure 3 ) was used to estimate the impervious surface for the first year of record. Then the subsequent year for which the population density indicated a 15 percent increase in impervious surface was identified. For example, the impervious surface increased 15 percent at Ramapo River near Mahwah (01387500) (from 2.6 percent to 17.6 percent between 1923 and 1981).

\section{Evaluation of Breakpoints on Double-Mass Curves}

The 85 streamflow-gaging stations used to develop double-mass curves to relate cumulative annual streamflow to that at the index station are listed in table 12. The number of years of record available for each station, the index stations used to develop double-mass curves, and whether or not double-mass analysis was performed also are listed. Results of double-mass analysis for 85 gages are presented in tables 13 and 14. The years of record for the test station must coincide with the years of record for the index station in order to develop a meaningful double-mass curve. Stations from stream class A had an average of 67 years of record, stations from stream class B had an average of 57 years, stations from stream class $C$ had an average of 30 years, and stations from stream class D had an average of 19 years.

Double-mass curves were created for the 85 stations that had 10 or more years of record in common with the appropriate index station. Of these, 67 stations had one or more statistically significant breakpoints for either the base-flow or runoff datasets. Several stations had multiple significant breakpoints. Each breakpoint was visually inspected and selected for further analysis if the curve indicated a substantial change took place in the slope, or if the analysis of covariance identified the point as being the most significant breakpoint on the double-mass plot. Using these criteria, 64 stations with significant breakpoints were selected for further evaluation (table 13). These stations were assigned values for breakpoint appearance, slope ratio, and breakpoint prominence scores. A final rating then was calculated for each breakpoint.

Results of the rating of all breakpoints that were considered "moderate" or stronger are given in table 14. Those breakpoints that were interpreted as "weak" were not considered for determination of the baseline period. Of a total of 64 sites with statistically significant breakpoints selected for further analysis, 36 sites had breakpoints that were "moderate" or stronger.

Three stations had prominently visible breakpoints that were not significant according to the analysis of covariance unless one or more years of record were not considered in the analysis. The station at Raritan River below Calco Dam at Bound Brook (01403060), when related to index station 01443500 (Paulins Kill at Blairstown) had a significant breakpoint in 1981 but only when cumulative annual runoff data from 1944 -1960 were not considered. Similarly, the station at Crosswicks Creek at Extonville (01464500), when related to index station 01443500 (Paulins Kill at Blairstown), had a significant breakpoint only when data from 1939 to 1958 were not considered. This breakpoint had a p-value of 0.0008 and an F-value of 13.1. The station at Musconetcong River 


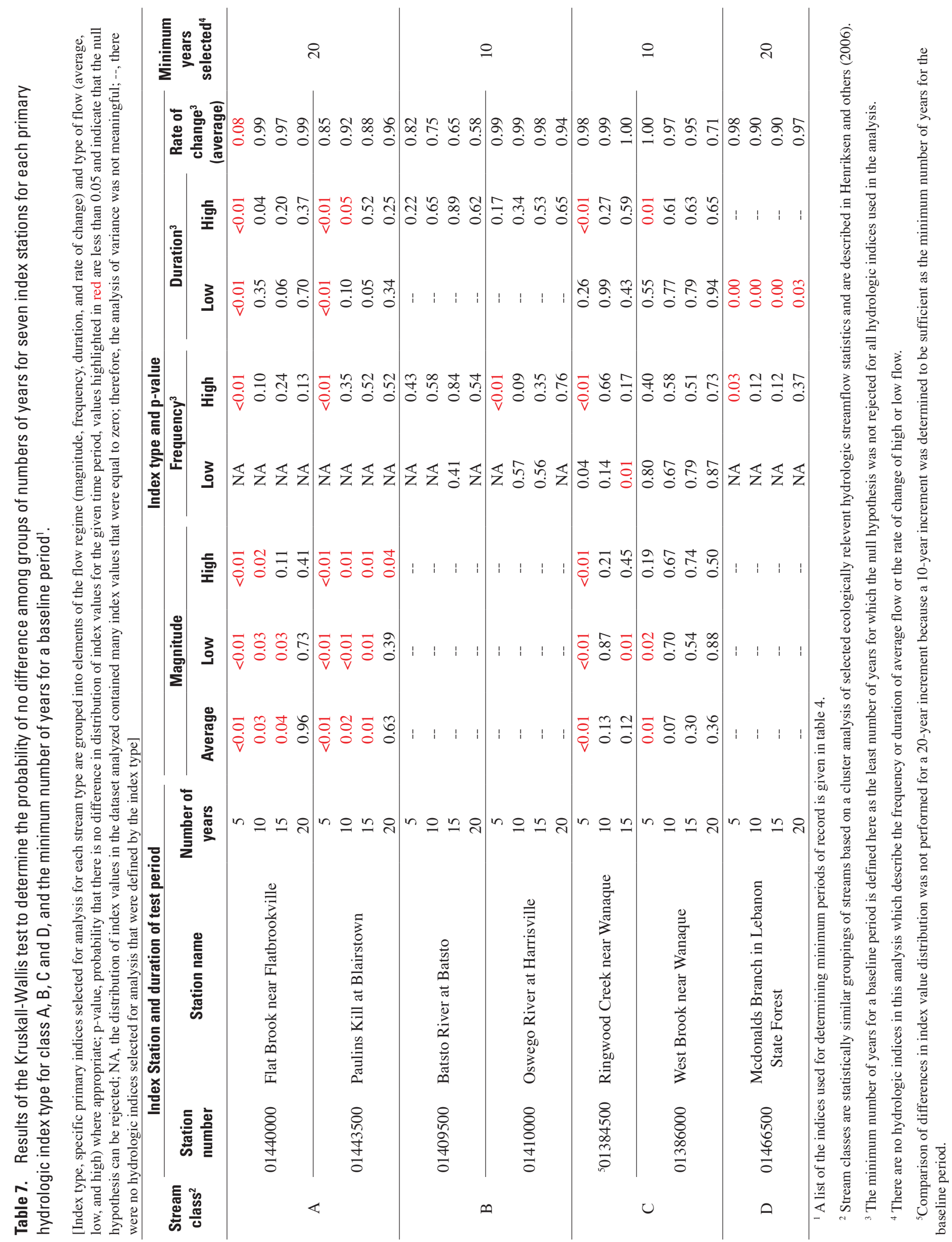




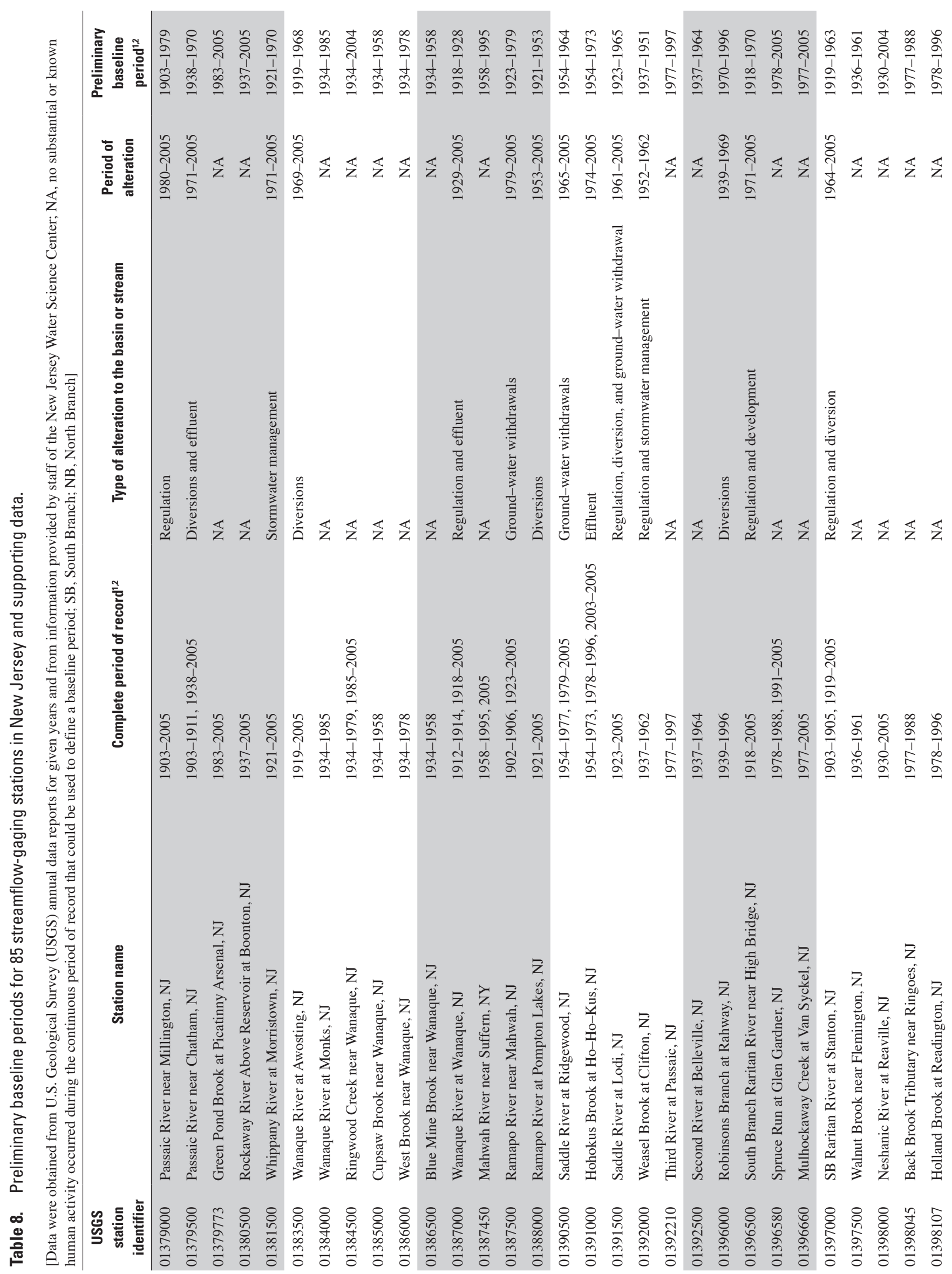




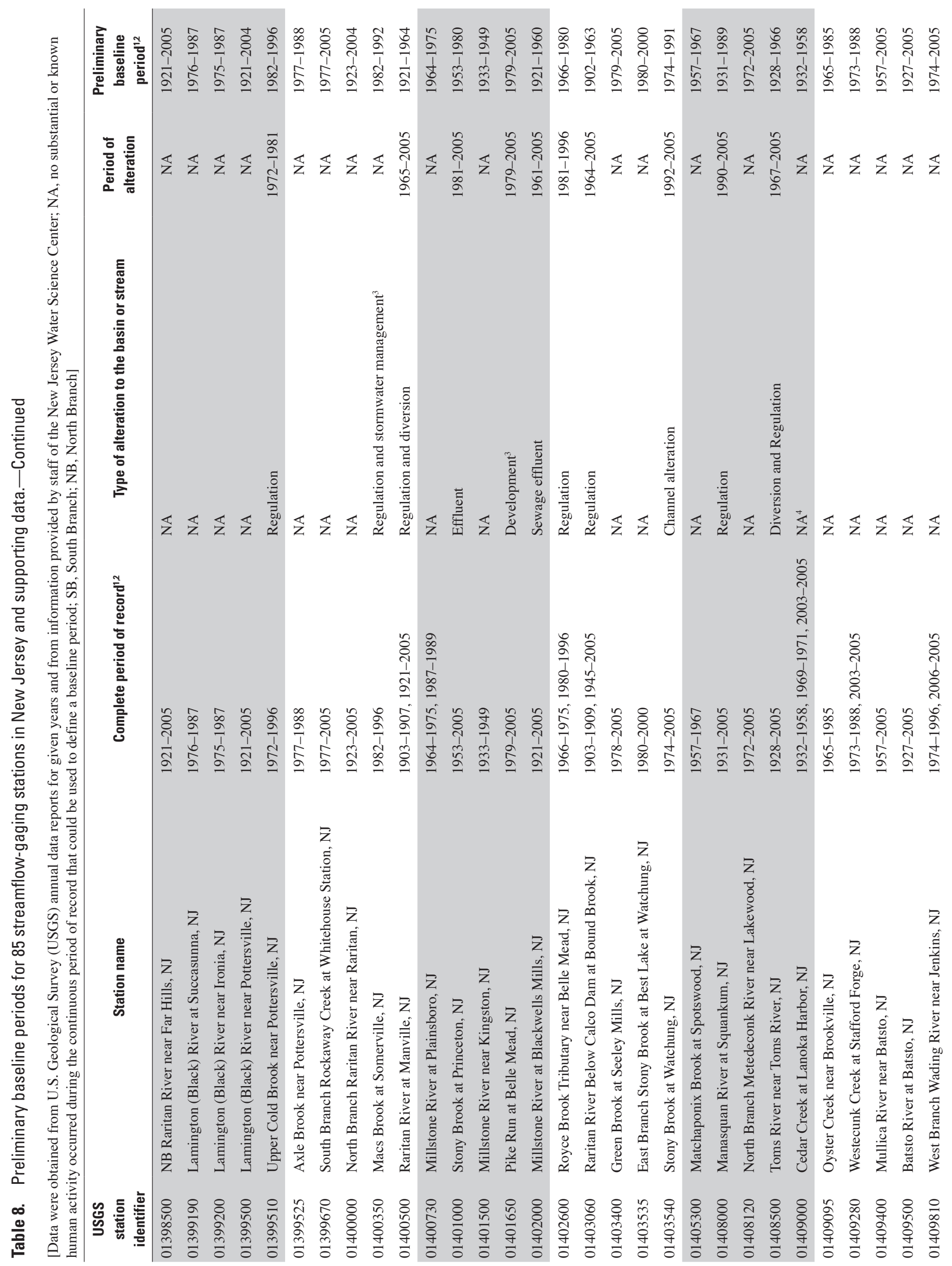




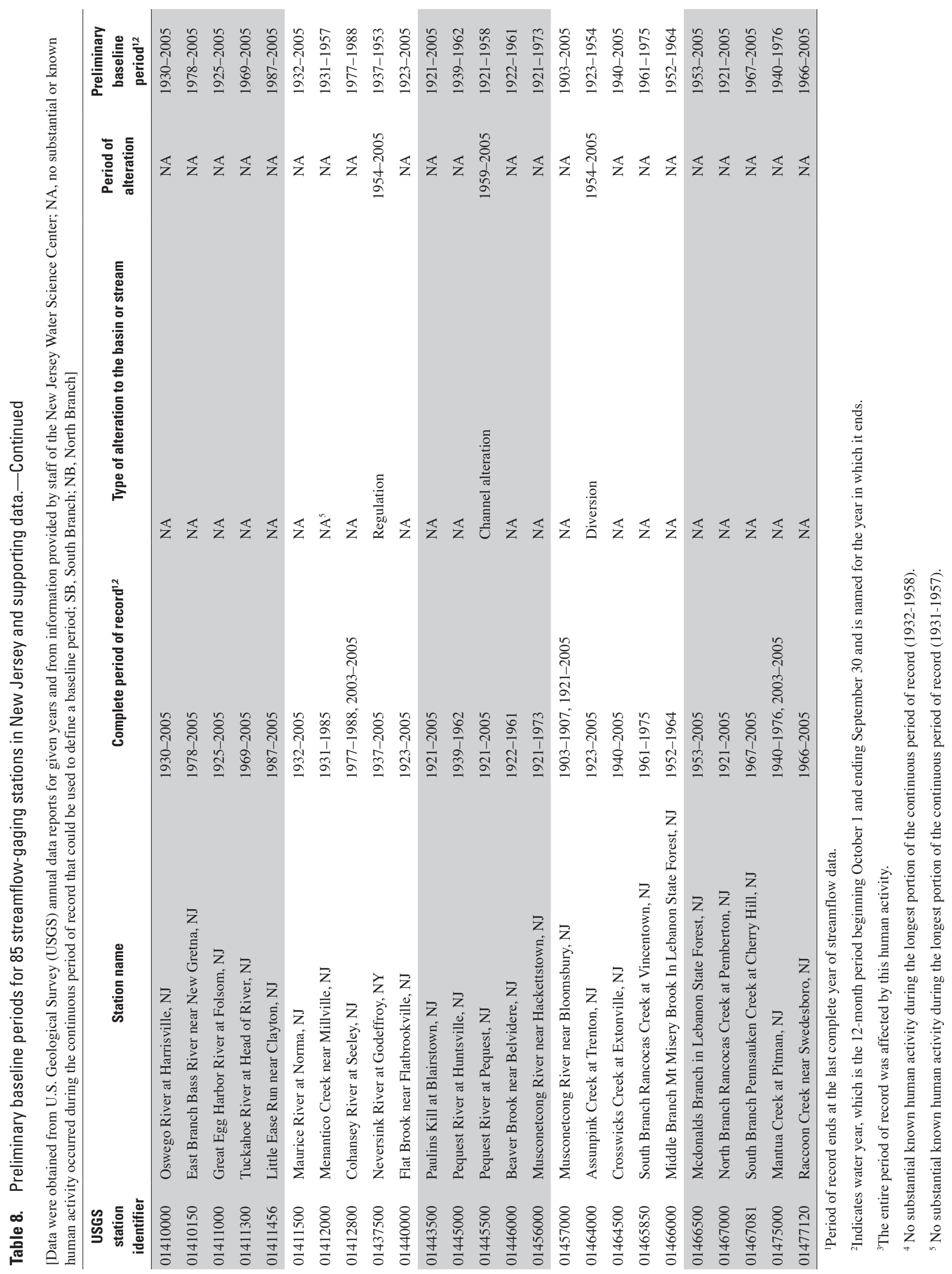


Table 9. Estimated percentages of impervious surface and correction factors for drainage basins of selected streamflow-gaging stations in New Jersey.

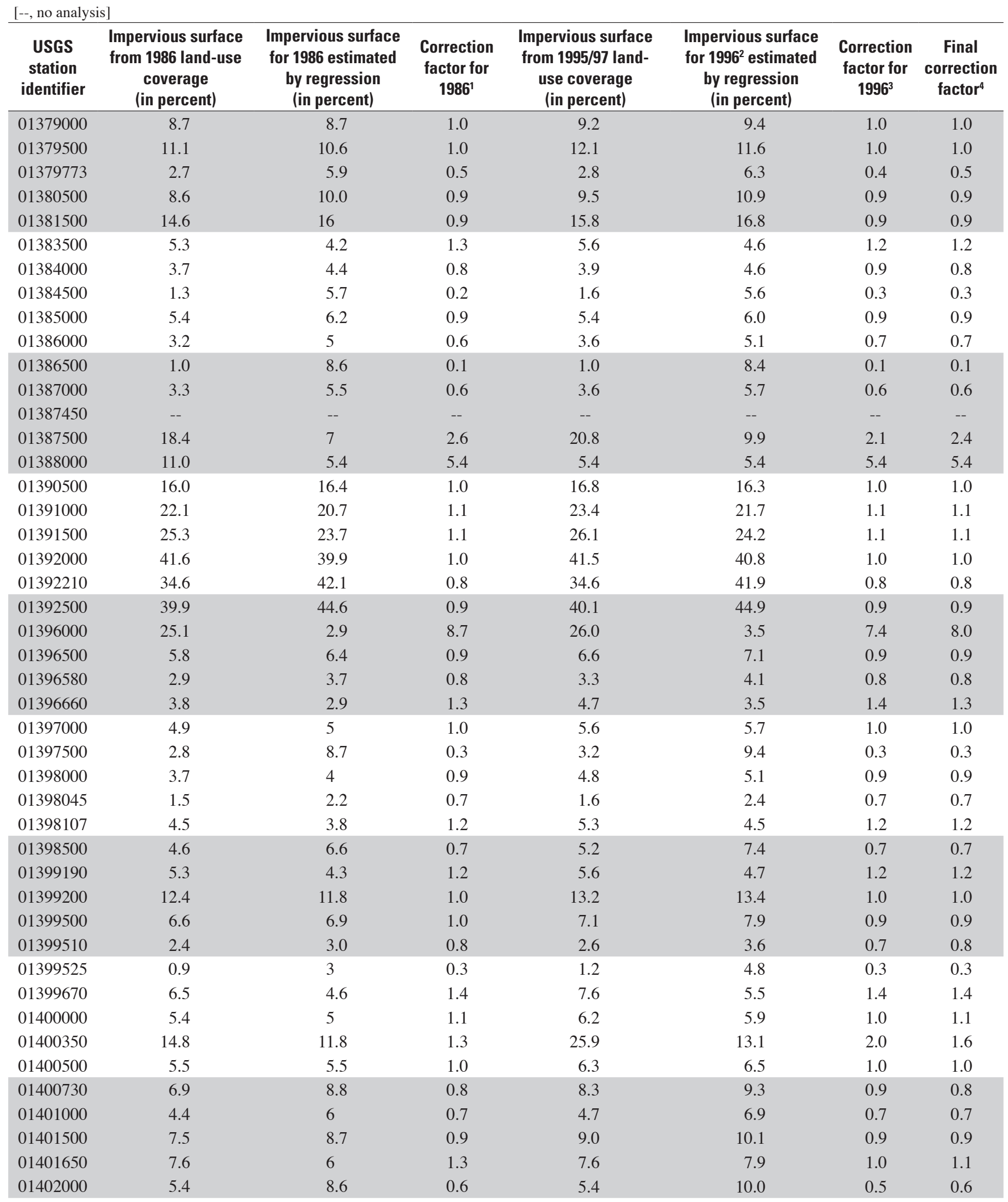


Table 9. Estimated percentages of impervious surface and correction factors for drainage basins of selected streamflow-gaging stations in New Jersey.-Continued

\begin{tabular}{|c|c|c|c|c|c|c|c|}
\hline 01402600 & 34.3 & 6.2 & 5.5 & 38.8 & 6.8 & 5.7 & 5.6 \\
\hline 01403060 & -- & -- & -- & -- & -- & -- & -- \\
\hline 01403400 & 12.5 & 20.3 & 0.6 & 13.3 & 21.1 & 0.6 & 0.6 \\
\hline 01403540 & 11.3 & 9.4 & 1.2 & 12.6 & 9.9 & 1.3 & 1.2 \\
\hline 01405300 & 11.2 & 10.3 & 1.1 & 13.5 & 12.8 & 1.1 & 1.1 \\
\hline 01408000 & 7.9 & 8.9 & 0.9 & 9.7 & 10.9 & 0.9 & 0.9 \\
\hline 01408120 & 10.0 & 8.2 & 1.2 & 11.3 & 10.4 & 1.1 & 1.2 \\
\hline 01408500 & 3.9 & 5.9 & 0.7 & 4.7 & 7.1 & 0.7 & 0.7 \\
\hline 01409400 & 1.4 & 4 & 0.4 & 1.5 & 4.5 & 0.3 & 0.3 \\
\hline 01409500 & 0.9 & 1.8 & 0.5 & 1.1 & 1.9 & 0.6 & 0.5 \\
\hline 01409810 & 0.2 & 0.8 & 0.2 & 0.2 & 0.7 & 0.2 & 0.2 \\
\hline 01410000 & 0.1 & 1.7 & 0.1 & 0.1 & 2.1 & 0.1 & 0.1 \\
\hline 01410150 & 0.5 & 0.7 & 0.7 & 0.5 & 0.7 & 0.7 & 0.7 \\
\hline 01411000 & 7.1 & 7.6 & 0.9 & 8.7 & 9.3 & 0.9 & 0.9 \\
\hline 01411300 & 0.6 & 1.4 & 0.5 & 0.7 & 1.7 & 0.4 & 0.4 \\
\hline 01411456 & 4.9 & 12.5 & 0.4 & 5.4 & 14.3 & 0.4 & 0.4 \\
\hline 01411500 & 4.9 & 6.3 & 0.8 & 5.6 & 6.9 & 0.8 & 0.8 \\
\hline 01412000 & 6.4 & 8.2 & 0.8 & 7.0 & 8.4 & 0.8 & 0.8 \\
\hline 01456000 & 5.8 & 8.9 & 0.6 & 6.3 & 9.3 & 0.7 & 0.7 \\
\hline 01457000 & 4.9 & 7 & 0.7 & 5.4 & 7.5 & 0.7 & 0.7 \\
\hline 01464000 & 13.5 & 13.7 & 1.0 & 14.9 & 14.7 & 1.0 & 1.0 \\
\hline 01464500 & 4.3 & 3.9 & 1.1 & 4.5 & 3.8 & 1.2 & 1.1 \\
\hline 01465850 & 2.1 & 2.7 & 0.8 & 2.2 & 2.7 & 0.8 & 0.8 \\
\hline 01466000 & 0.2 & 13.7 & 0.0 & 0.0 & 14.7 & 0.0 & 0.0 \\
\hline 01466500 & 0.0 & 0.7 & 0.0 & 0.0 & 0.6 & 0.0 & 0.0 \\
\hline 01467000 & 2.6 & 4.9 & 0.5 & 2.5 & 4.9 & 0.5 & 0.5 \\
\hline 01467081 & 35.6 & 22.8 & 1.6 & 39.6 & 24.1 & 1.6 & 1.6 \\
\hline 01475000 & 13.4 & 18.5 & 0.7 & 18.3 & 21.3 & 0.9 & 0.8 \\
\hline 01477120 & 3.1 & 3.6 & 0.9 & 4.0 & 4.9 & 0.8 & 0.8 \\
\hline
\end{tabular}

${ }^{1}$ Correction factor is determined by dividing the percentage impervious surface from the 1986 land-use coverage by the percentage impervious surface for 1986 estimated by regression.

${ }^{2}$ Estimated by linear interpolation between the population density estimate for 1990 and for 2000.

${ }^{3}$ Correction factor is determined by dividing the percentage impervious surface from the $1995 / 97$ land-use coverage by the percentage impervious surface for 1995 estimated by regression.

${ }^{4}$ Correction factor is determined by averaging the correction factor for 1986 and the correction factor for 1996. 
Table 10. Years in which estimated impervious surface in the drainage basins of selected streamflow-gaging stations in New Jersey exceeded 10 percent or 20 percent of the drainage basin area, or had increased by 15 percent.

[\%, percent; --, did not exceed indicated percentage]

\begin{tabular}{|c|c|c|c|c|}
\hline $\begin{array}{l}\text { USGS station } \\
\text { identifier }\end{array}$ & Available period of record ${ }^{1}$ & $\begin{array}{c}\text { Year in which } \\
\text { impervious surface } \\
\text { exceeded } 10 \%\end{array}$ & $\begin{array}{c}\text { Year in which } \\
\text { impervious surface } \\
\text { exceeded } 20 \%\end{array}$ & $\begin{array}{c}\text { Year in which } \\
\text { impervious surface } \\
\text { had increased by } 15 \%^{2}\end{array}$ \\
\hline 01379000 & 1903-2005 & -- & -- & -- \\
\hline 01379500 & 1903-1911, 1938-2005 & 1966 & -- & -- \\
\hline 01379773 & 1983-2005 & -- & -- & -- \\
\hline 01380500 & $1937-2005$ & 1996 & -- & -- \\
\hline 01384000 & $1934-1985$ & -- & -- & -- \\
\hline 01384500 & 1934-1979, 1985-2005 & -- & -- & -- \\
\hline 01385000 & $1934-1958$ & -- & -- & -- \\
\hline 01386000 & 1934-1978 & -- & -- & -- \\
\hline 01388000 & $1921-2005$ & 1966 & -- & -- \\
\hline 01390500 & 1954-1977, 1979-2005 & -- & -- & -- \\
\hline 01391000 & 1954-1973, 1978-1996, 2003-2005 & 1947 & 1965 & -- \\
\hline 01391500 & 1923-2005 & 1937 & 1957 & ${ }^{4} 1955$ \\
\hline 01392000 & $1937-1962$ & Before 1930 & Before 1930 & -- \\
\hline 01392210 & 1977-1997 & Before 1930 & Before 1930 & -- \\
\hline 01392500 & $1937-1964$ & Before 1930 & Before 1930 & -- \\
\hline 01396000 & 1939-1996 & 1963 & 1986 & 1987 \\
\hline 01396500 & 1918-2005 & -- & -- & -- \\
\hline 01398500 & 1921-2005 & -- & -- & -- \\
\hline 01399190 & 1976-1987 & -- & -- & -- \\
\hline 01399200 & 1975-1987 & 1971 & -- & -- \\
\hline 01399500 & $1921-2005$ & -- & -- & -- \\
\hline 01399510 & 1972-1996 & -- & -- & -- \\
\hline 01399525 & $1977-1988$ & -- & -- & -- \\
\hline 01399670 & 1977-2005 & -- & -- & -- \\
\hline 01400000 & 1923-2005 & -- & -- & -- \\
\hline 01400350 & 1982-1996 & 1957 & 1991 & -- \\
\hline 01400500 & 1903-1907, 1921-2005 & -- & -- & -- \\
\hline 01400730 & 1964-1975, 1987-1989 & -- & -- & -- \\
\hline 01401000 & 1953-2005 & -- & -- & -- \\
\hline 01401500 & 1933-1949 & -- & -- & -- \\
\hline 01401650 & 1979-2005 & 1999 & -- & -- \\
\hline 01402000 & $1921-2005$ & -- & -- & -- \\
\hline 01402600 & 1966-1975, 1980-1996 & 1958 & 1973 & 1982 \\
\hline
\end{tabular}


Table 10. Years in which estimated impervious surface in the drainage basins of selected streamflow-gaging stations in New Jersey exceeded 10 percent or 20 percent of the drainage basin area, or had increased by 15 percent.-Continued

$[\%$, percent; --, did not exceed indicated percentage $]$

\begin{tabular}{|c|c|c|c|c|}
\hline $\begin{array}{l}\text { USGS station } \\
\text { identifier }\end{array}$ & Available period of record ${ }^{1}$ & $\begin{array}{l}\text { Year in which } \\
\text { impervious surface } \\
\text { exceeded } 10 \%\end{array}$ & $\begin{array}{c}\text { Year in which } \\
\text { impervious surface } \\
\text { exceeded } 20 \%\end{array}$ & $\begin{array}{c}\text { Year in which } \\
\text { impervious surface } \\
\text { had increased by } 15 \%{ }^{2}\end{array}$ \\
\hline 01403060 & 1903-1909, 1945-2005 & -- & -- & -- \\
\hline 01403400 & $1978-2005$ & 1957 & -- & -- \\
\hline 01403535 & 1980-2000 & -- & -- & -- \\
\hline 01403540 & $1974-2005$ & 1968 & -- & -- \\
\hline 01405300 & $1957-1967$ & 1983 & -- & -- \\
\hline 01408000 & $1931-2005$ & 1997 & -- & -- \\
\hline 01408120 & $1972-2005$ & 1989 & -- & -- \\
\hline 01408500 & 1928-2005 & -- & -- & -- \\
\hline 01409000 & 1932-1958, 1969-1971, 2003-2005 & -- & -- & -- \\
\hline 01409095 & $1965-1985$ & -- & -- & -- \\
\hline 01409280 & 1973-1988, 2003-2005 & -- & -- & -- \\
\hline 01409400 & $1957-2005$ & -- & -- & -- \\
\hline 01409500 & $1927-2005$ & -- & -- & -- \\
\hline 01409810 & $1974-1996,2006-2005$ & -- & -- & -- \\
\hline 01410000 & $1930-2005$ & -- & -- & -- \\
\hline 01410150 & $1978-2005$ & -- & -- & -- \\
\hline 01411000 & $1925-2005$ & -- & -- & -- \\
\hline 01411300 & 1969-2005 & -- & -- & -- \\
\hline 01411456 & 1987-2005 & -- & -- & -- \\
\hline 01411500 & $1932-2005$ & -- & -- & -- \\
\hline 01412000 & $1931-1985$ & -- & -- & -- \\
\hline 01412800 & 1977-1988, 2003-2005 & -- & -- & -- \\
\hline 01437500 & 1937-2005 & -- & -- & -- \\
\hline 01440000 & $1923-2005$ & -- & -- & -- \\
\hline 01443500 & $1921-2005$ & -- & -- & -- \\
\hline 01445000 & 1939-1962 & -- & -- & -- \\
\hline 01445500 & $1921-2005$ & -- & -- & -- \\
\hline 01446000 & $1922-1961$ & -- & -- & -- \\
\hline 01456000 & $1921-1973$ & -- & -- & -- \\
\hline 01457000 & 1903-1907, 1921-2005 & -- & -- & -- \\
\hline 01464000 & $1923-2005$ & -- & 1997 & -- \\
\hline 01464500 & 1940-2005 & -- & -- & -- \\
\hline 01465850 & $1961-1975$ & -- & -- & -- \\
\hline 01466000 & $1952-1964$ & -- & -- & -- \\
\hline 01466500 & $1953-2005$ & -- & -- & -- \\
\hline 01467000 & $1921-2005$ & -- & -- & -- \\
\hline 01467081 & 1967-2005 & 1950 & 1960 & ${ }^{5}$ After 2005 \\
\hline 01475000 & 1940-1976, 2003-2005 & 1972 & -- & -- \\
\hline 01477120 & 1966-2005 & -- & -- & -- \\
\hline
\end{tabular}

${ }^{1}$ From the value of estimated impervious surface at the beginning of the continuous period of record, in water years.

${ }^{2}$ Indicates water year, which is the 12-month period beginning October 1 and ending September 30 and is named for the year in which it ends.

${ }^{3}$ Least-square regression used to estimate 15 -percent change in impervious surface since $1923 ;$ IS $=8^{*} 10^{-21} \mathrm{e}^{024(\mathrm{Y})}, \mathrm{R}^{2}=0.97$.

${ }^{4}$ Least-squares regression used to estimate 15-percent change in impervious surface since 1923 using estimated values from 1930-1970; IS $=.492 *(\mathrm{Y})-943.3, \mathrm{R}^{2}=0.97$.

${ }^{5}$ Least-square regression used to estimate 15-percent change in impervious surface since 1967 using estimated values from 1970-2000; IS $=0.26^{*}(\mathrm{Y})-481.2, \mathrm{R}^{2}=0.97$. 
Table 11. Estimated population density in drainage basins of 83 selected streamflow-gaging stations in New Jersey, by decade.

$[--$, no analysis $]$

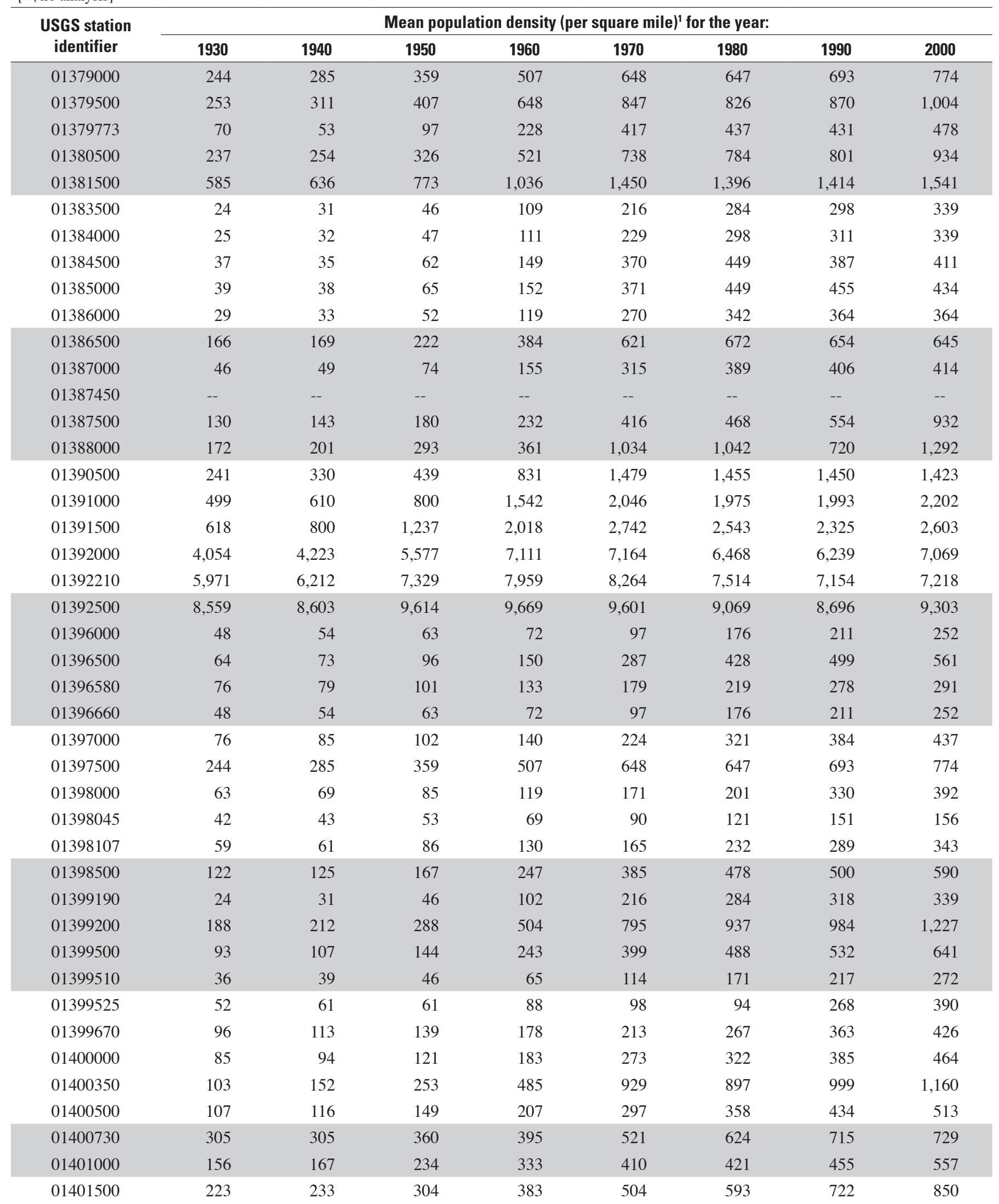


Table 11. Estimated population density in drainage basins of 83 selected streamflow-gaging stations in New Jersey, by decade.-Continued

\begin{tabular}{|c|c|c|c|c|c|c|c|c|}
\hline \multirow{2}{*}{$\begin{array}{l}\text { USGS station } \\
\text { identifier }\end{array}$} & \multicolumn{8}{|c|}{ Mean population density (per square mile) ${ }^{1}$ for the year: } \\
\hline & 1930 & 1940 & 1950 & 1960 & 1970 & 1980 & 1990 & 2000 \\
\hline 01401650 & 45 & 53 & 75 & 136 & 201 & 337 & 505 & 674 \\
\hline 01402000 & 187 & 199 & 262 & 360 & 507 & 581 & 714 & 840 \\
\hline 01402600 & 42 & 48 & 71 & 138 & 201 & 347 & 525 & 500 \\
\hline 01403060 & 136 & 147 & 193 & 268 & 381 & 446 & 543 & 641 \\
\hline 01403400 & 557 & 635 & 863 & 1,685 & 2,098 & 1,985 & 1,893 & 2,132 \\
\hline 01403535 & 149 & 190 & 299 & 544 & 781 & 869 & 840 & 1,293 \\
\hline 01403540 & 118 & 158 & 247 & 447 & 653 & 731 & 733 & 814 \\
\hline 01405300 & 265 & 289 & 357 & 420 & 617 & 708 & 890 & 1,173 \\
\hline 01408000 & 141 & 158 & 201 & 279 & 485 & 575 & 770 & 939 \\
\hline 01408120 & 62 & 77 & 118 & 194 & 390 & 508 & 705 & 907 \\
\hline 01408500 & 34 & 38 & 60 & 108 & 233 & 377 & 470 & 566 \\
\hline 01409000 & 8 & 9 & 12 & 27 & 59 & 181 & 282 & 318 \\
\hline 01409095 & 13 & 14 & 17 & 29 & 65 & 127 & 183 & 209 \\
\hline 01409280 & 13 & 15 & 16 & 21 & 44 & 109 & 162 & 207 \\
\hline 01409400 & 53 & 57 & 67 & 93 & 138 & 240 & 302 & 322 \\
\hline 01409500 & 9 & 10 & 16 & 21 & 30 & 92 & 112 & 116 \\
\hline 01409810 & 8 & 11 & 13 & 17 & 19 & 32 & 33 & 27 \\
\hline 01410000 & 12 & 13 & 14 & 17 & 24 & 82 & 113 & 141 \\
\hline 01410150 & 9 & 8 & 9 & 9 & 11 & 20 & 25 & 26 \\
\hline 01411000 & 138 & 140 & 165 & 259 & 349 & 497 & 625 & 796 \\
\hline 01411300 & 29 & 29 & 30 & 36 & 43 & 63 & 91 & 99 \\
\hline 01411456 & 307 & 311 & 385 & 646 & 810 & 974 & 1,073 & 1,316 \\
\hline 01411500 & 142 & 149 & 194 & 280 & 349 & 435 & 487 & 530 \\
\hline 01412000 & 235 & 262 & 335 & 432 & 529 & 611 & 635 & 647 \\
\hline 01412800 & 59 & 61 & 119 & 144 & 159 & 166 & 168 & 178 \\
\hline 01437500 & -- & -- & -- & -- & -- & -- & -- & -- \\
\hline 01440000 & 13 & 14 & 16 & 21 & 27 & 34 & 41 & 46 \\
\hline 01443500 & 73 & 77 & 86 & 116 & 150 & 205 & 223 & 244 \\
\hline 01445000 & 46 & 51 & 68 & 114 & 163 & 232 & 260 & 284 \\
\hline 01445500 & 41 & 43 & 52 & 76 & 108 & 165 & 200 & 231 \\
\hline 01446000 & 33 & 37 & 40 & 47 & 62 & 85 & 103 & 114 \\
\hline 01456000 & 83 & 93 & 127 & 230 & 470 & 682 & 702 & 744 \\
\hline 01457000 & 88 & 98 & 125 & 198 & 371 & 507 & 531 & 583 \\
\hline 01464000 & 512 & 559 & 685 & 891 & 1,060 & 1,082 & 1,200 & 1,310 \\
\hline 01464500 & 36 & 43 & 180 & 305 & 347 & 267 & 268 & 255 \\
\hline 01465850 & 25 & 29 & 40 & 67 & 98 & 167 & 187 & 180 \\
\hline 01466000 & 512 & 559 & 685 & 891 & 1,060 & 1,083 & 1,200 & 1,310 \\
\hline 01466500 & 10 & 14 & 16 & 20 & 21 & 24 & 22 & 15 \\
\hline 01467000 & 23 & 28 & 98 & 192 & 239 & 330 & 356 & 350 \\
\hline 01467081 & 277 & 291 & 412 & 1,015 & 1,841 & 2,159 & 2,363 & 2,542 \\
\hline 01475000 & 279 & 283 & 344 & 581 & 1,015 & 1,434 & 1,892 & 2,180 \\
\hline 01477120 & 100 & 100 & 123 & 154 & 176 & 218 & 268 & 404 \\
\hline
\end{tabular}

${ }^{1}$ Mean population density was estimated for each drainage basin using historic census data for municipalities in New Jersey (U.S. Census Bureau, 2007). 


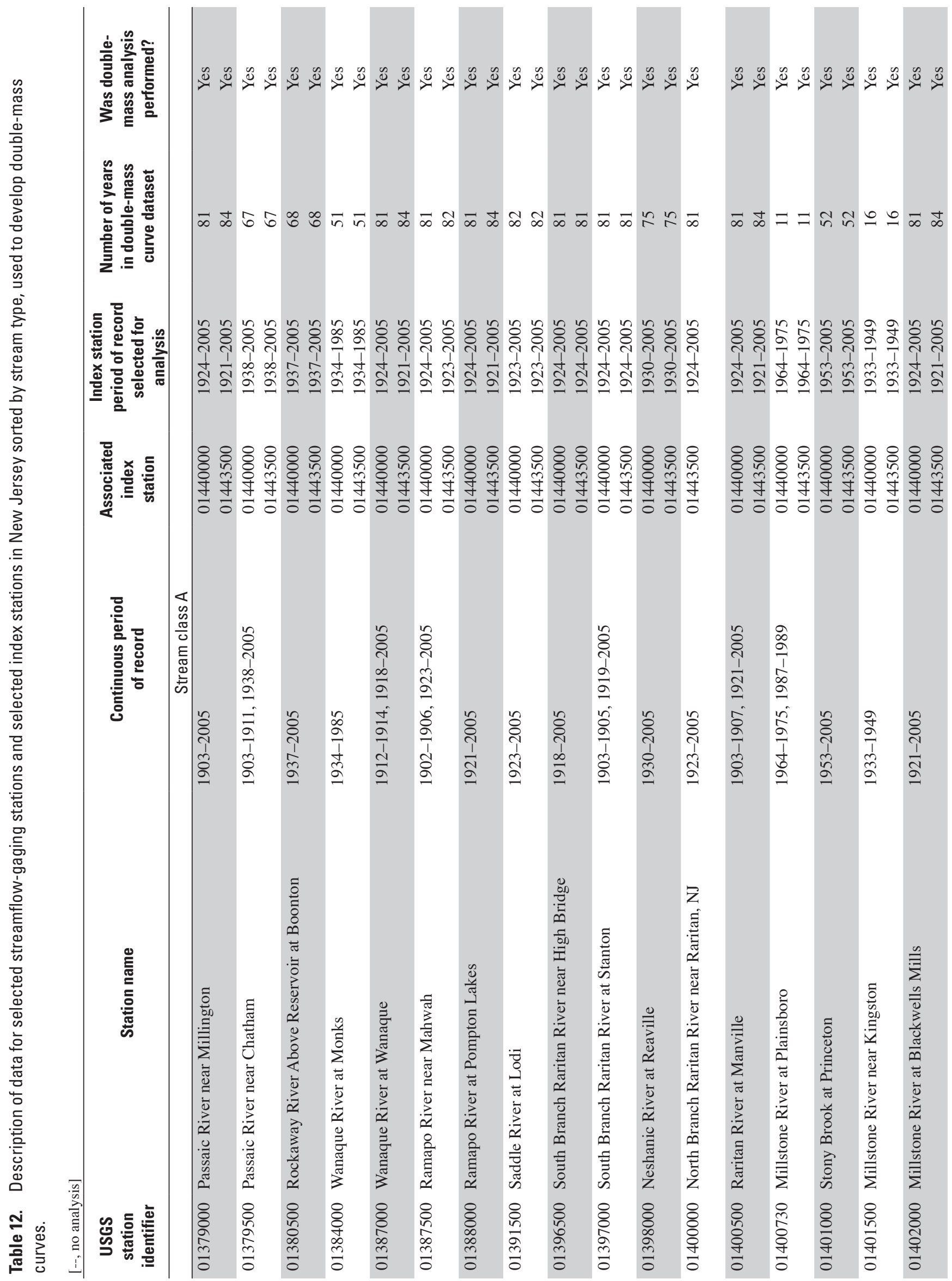



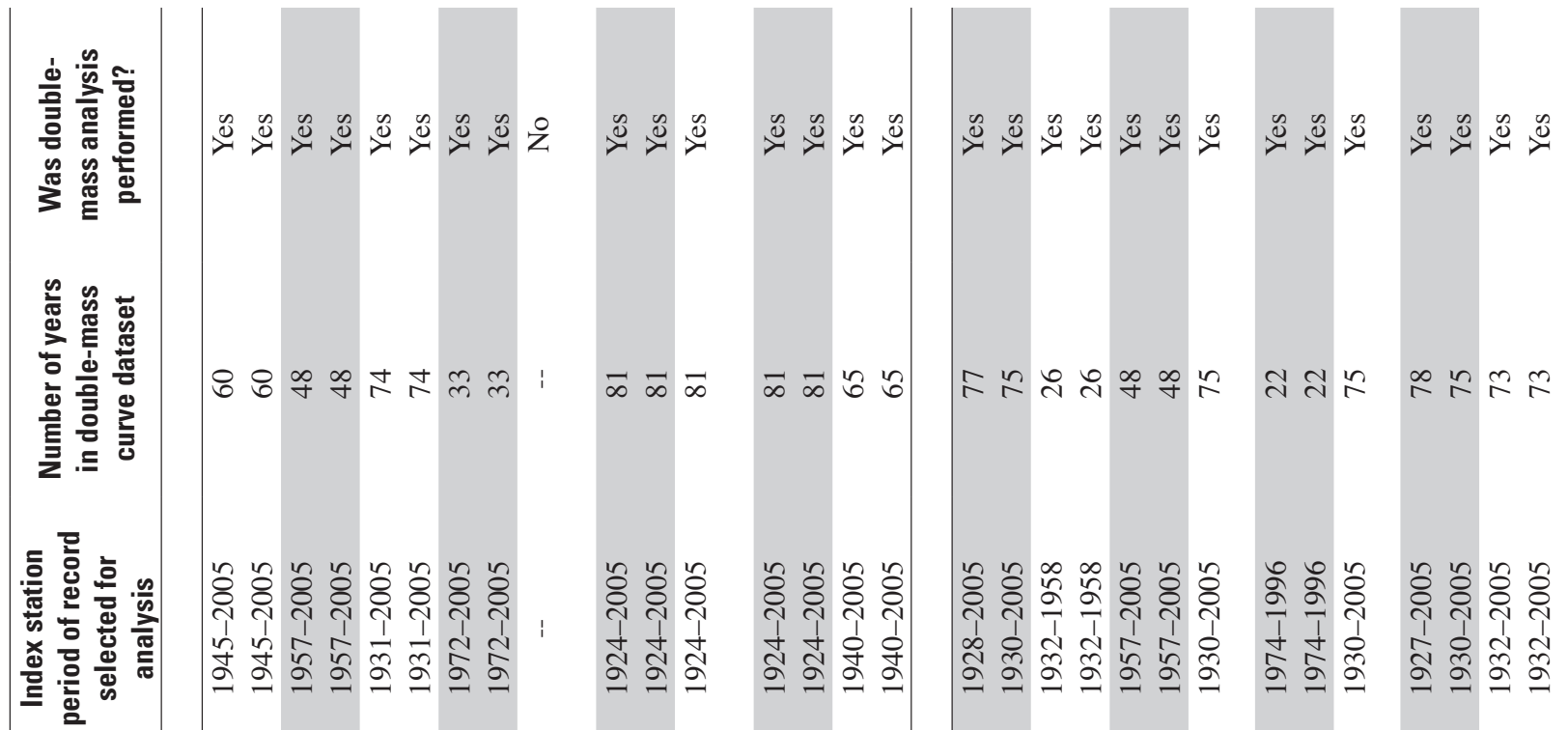

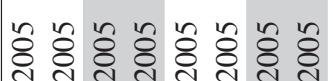

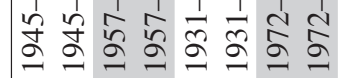

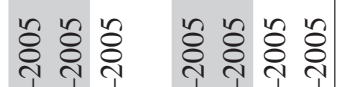

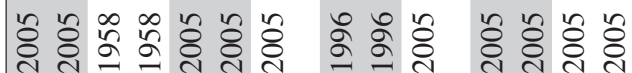

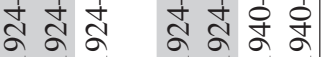

雨

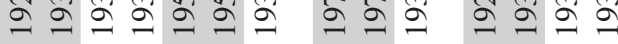

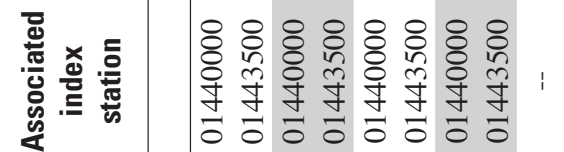

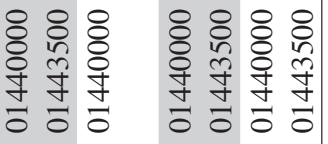

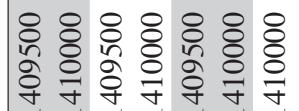
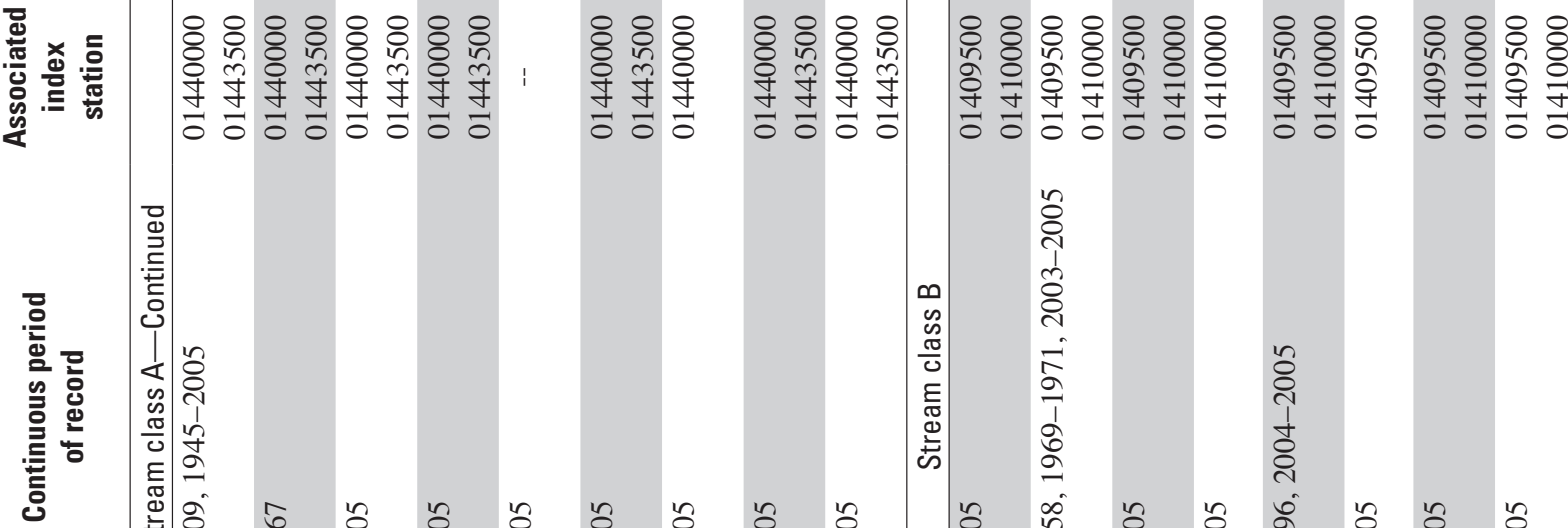

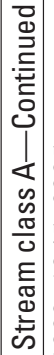

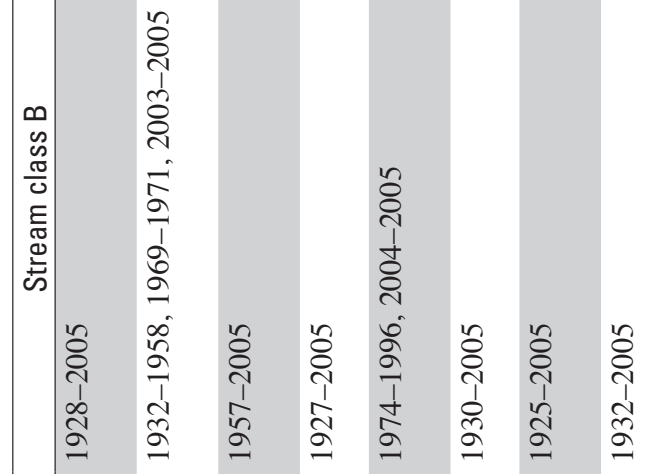

递

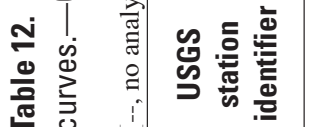

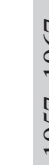

ڤి

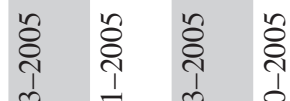

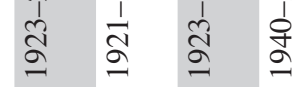

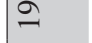




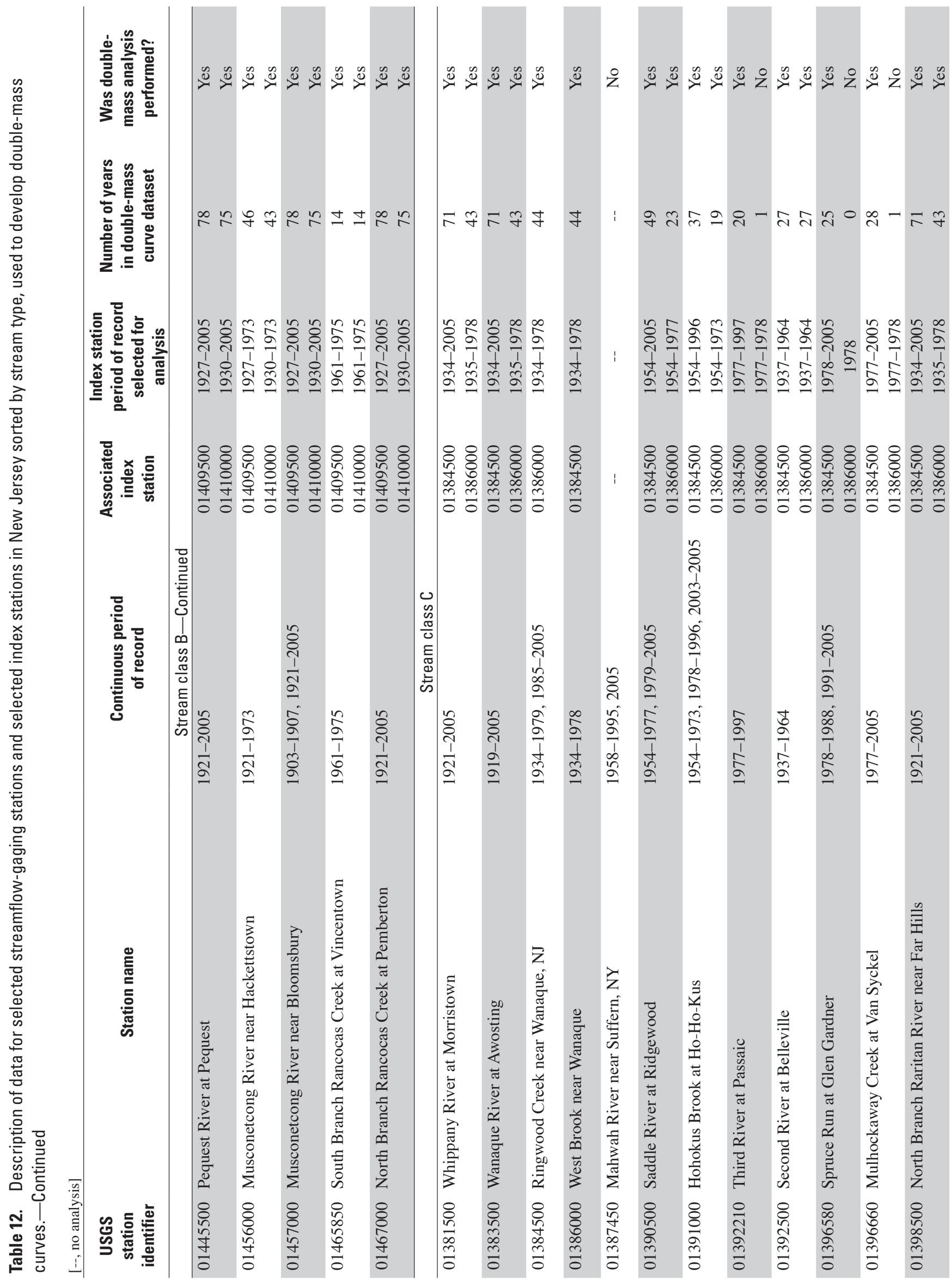




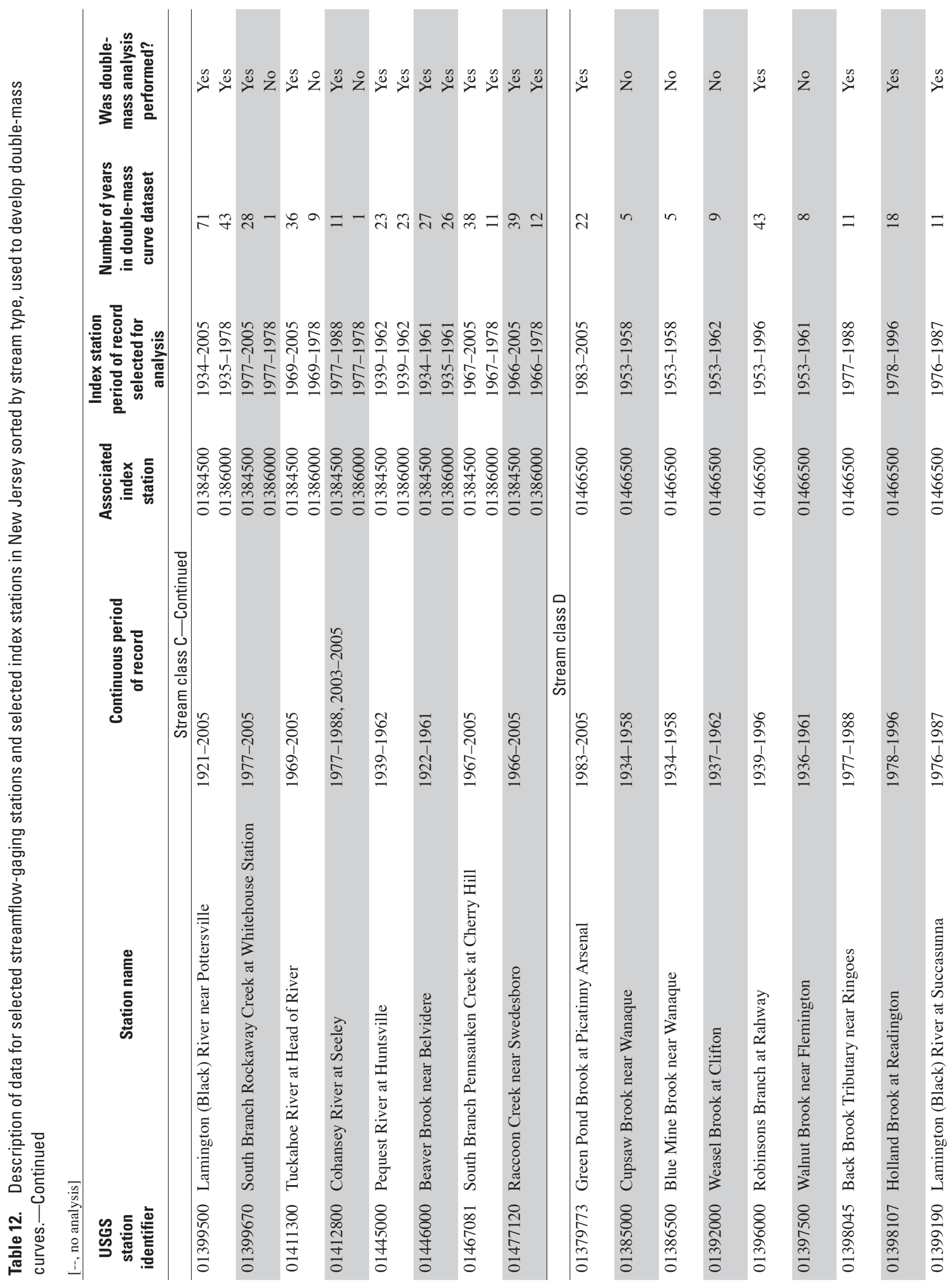




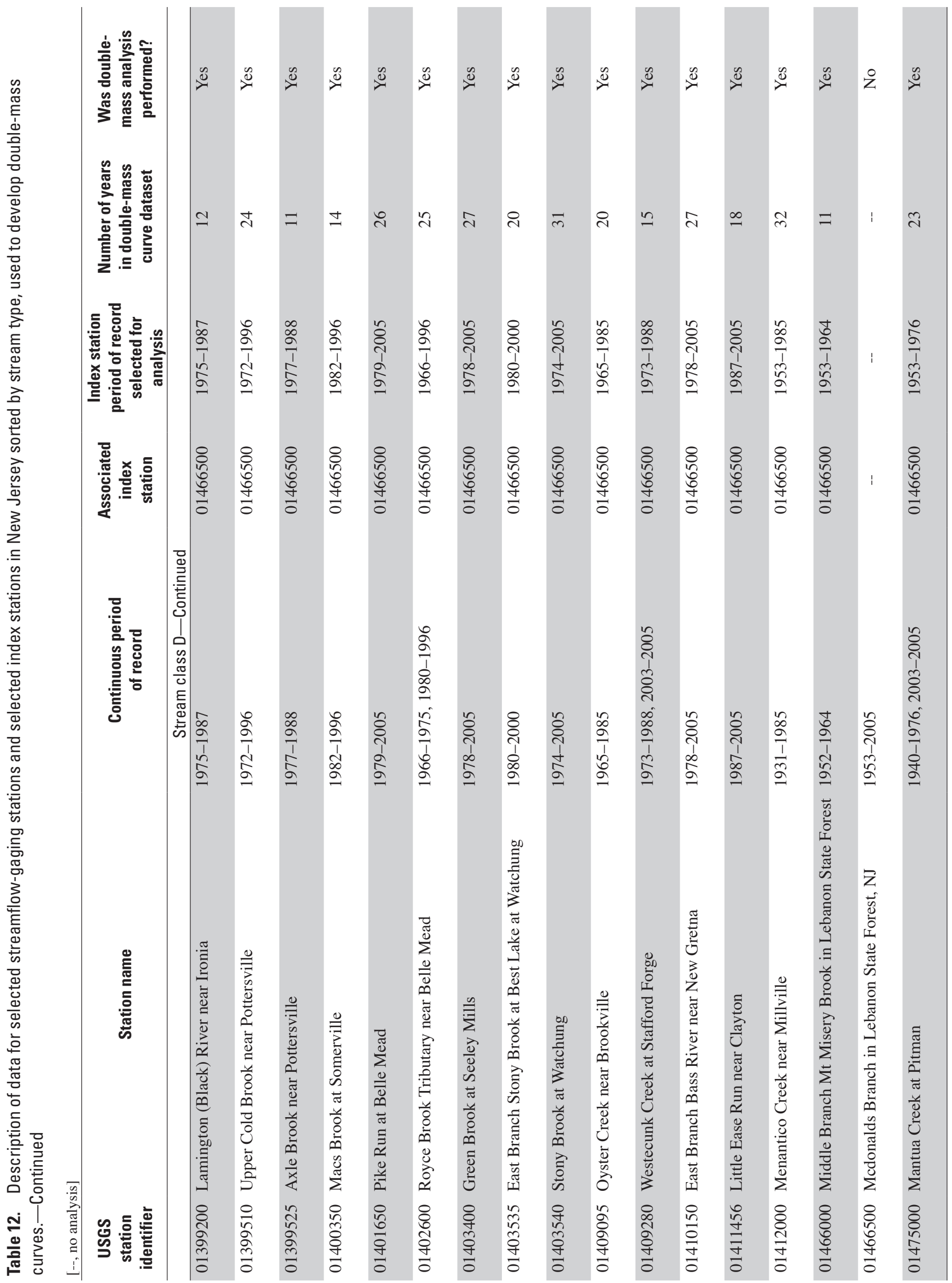


Table 13. Selected results of analysis of covariance conducted on double-mass curves for 85 streamflow-gaging stations and selected index streamflow-gaging stations on the same stream type in New Jersey.

[No BP identified, no significant breakpoints were detected on the double-mass curve; --, not applicable; No BP considered, no significant breakpoints were considered for further analysis; No analysis, double-mass analysis was not performed; <, less than]

\begin{tabular}{|c|c|c|c|c|c|c|c|c|}
\hline $\begin{array}{c}\text { USGS } \\
\text { station } \\
\text { identifier }\end{array}$ & Period of record ${ }^{1}$ & $\begin{array}{l}\text { Stream } \\
\text { class }\end{array}$ & $\begin{array}{c}\text { Breakpoint } \\
\text { year }\end{array}$ & $\begin{array}{l}\text { Index } \\
\text { station }\end{array}$ & Flow type & F-value & p-value & $\begin{array}{l}\text { Is F-value the } \\
\text { maximum } \\
\text { for the F-test } \\
\text { dataset? }\end{array}$ \\
\hline \multirow[t]{3}{*}{01379000} & $1903-2005$ & A & 1927 & 01440000 & Base flow & 21.625 & $<0.0001$ & Yes \\
\hline & & & 1950 & 01440000 & Base flow & 5.896 & 0.0174 & No \\
\hline & & & 1950 & 01443500 & Base flow & 11.293 & 0.0012 & Yes \\
\hline \multirow[t]{5}{*}{01379500} & 1903-1911, 1938-2005 & A & 1941 & 01440000 & Base flow & 9.605 & 0.0029 & Yes \\
\hline & & & 1941 & 01443500 & Base flow & 9.305 & 0.0033 & Yes \\
\hline & & & 1956 & 01440000 & Runoff & 5.961 & 0.0173 & Yes \\
\hline & & & 1956 & 01443500 & Runoff & 9.949 & 0.0024 & Yes \\
\hline & & & 1964 & 01443500 & Runoff & 4.987 & 0.0289 & No \\
\hline 01379773 & 1983-2005 & D & 1995 & 01466500 & Runoff & 5.530 & 0.0290 & Yes \\
\hline \multirow[t]{5}{*}{01380500} & 1937-2005 & $\mathrm{A}$ & 1941 & 01440000 & Base flow & 7.691 & 0.0072 & Yes \\
\hline & & & 1941 & 01443500 & Base flow & 5.734 & 0.0195 & Yes \\
\hline & & & 1959 & 01443500 & Runoff & 12.797 & 0.0007 & Yes \\
\hline & & & 1989 & 01440000 & Base flow & 4.937 & 0.0297 & No \\
\hline & & & 1992 & 01443500 & Base flow & 4.264 & 0.0429 & No \\
\hline \multirow[t]{3}{*}{01381500} & $1921-2005$ & $\mathrm{C}$ & 1971 & 01384500 & Runoff & 5.090 & 0.0270 & No \\
\hline & & & 1971 & 01386000 & Runoff & 4.490 & 0.0400 & Yes \\
\hline & & & 1974 & 01384500 & Runoff & 6.130 & 0.0160 & Yes \\
\hline \multirow[t]{3}{*}{01383500} & 1919-2005 & $\mathrm{C}$ & 1945 & 01386000 & Base flow & 9.601 & 0.0033 & Yes \\
\hline & & & 1978 & 01384500 & Base flow & 5.828 & 0.0186 & Yes \\
\hline & & & 1989 & 01384500 & Runoff & 6.920 & 0.0107 & Yes \\
\hline \multirow[t]{6}{*}{01384000} & 1935-1985 & A & 1939 & 01440000 & Base flow & 7.661 & 0.0079 & Yes \\
\hline & & & 1939 & 01440000 & Runoff & 7.487 & 0.0086 & Yes \\
\hline & & & 1950 & 01440000 & Runoff & 4.682 & 0.0353 & No \\
\hline & & & 1950 & 01443500 & Runoff & 9.059 & 0.0041 & Yes \\
\hline & & & 1954 & 01440000 & Base flow & 4.421 & 0.0406 & No \\
\hline & & & 1962 & 01443500 & Runoff & 7.642 & 0.0080 & No \\
\hline \multirow[t]{2}{*}{01384500} & $1934-2005$ & $\mathrm{C}$ & 1946 & 01386000 & Base flow & 8.018 & 0.0068 & Yes \\
\hline & & & 1953 & 01386000 & Runoff & 7.635 & 0.0082 & Yes \\
\hline 01385000 & $1936-1958$ & D & No BP identified & -- & -- & -- & -- & -- \\
\hline \multirow[t]{2}{*}{01386000} & $1935-1978$ & $\mathrm{C}$ & 1946 & 01384500 & Base flow & 6.152 & 0.0168 & Yes \\
\hline & & & 1952 & 01384500 & Runoff & 7.888 & 0.0073 & Yes \\
\hline 01386500 & $1935-1958$ & D & No Analysis ${ }^{2}$ & 01466500 & -- & -- & -- & -- \\
\hline \multirow[t]{10}{*}{01387000} & 1911-1914, 1918-2005 & A & 1927 & 01440000 & Runoff & 12.355 & 0.0007 & Yes \\
\hline & & & 1928 & 01440000 & Base flow & 24.870 & $<0.0001$ & No \\
\hline & & & 1929 & 01443500 & Base flow & 15.647 & 0.0002 & No \\
\hline & & & 1932 & 01440000 & Base flow & 27.432 & $<0.0001$ & Yes \\
\hline & & & 1932 & 01443500 & Base flow & 35.450 & $<0.0001$ & Yes \\
\hline & & & 1932 & 01443500 & Runoff & 14.171 & 0.0003 & Yes \\
\hline & & & 1939 & 01443500 & Base flow & 13.645 & 0.0004 & No \\
\hline & & & 1950 & 01440000 & Base flow & 4.537 & 0.0362 & No \\
\hline & & & 1952 & 01443500 & Base flow & 4.481 & 0.0373 & No \\
\hline & & & 1983 & 01443500 & Base flow & 4.026 & 0.0481 & No \\
\hline 01387450 & $1958-1995$ & $\mathrm{C}$ & No BP identified & -- & -- & -- & -- & -- \\
\hline \multirow[t]{4}{*}{01387500} & 1903-1906, 1923-2005 & A & 1957 & 01443500 & Runoff & 9.651 & 0.0026 & Yes \\
\hline & & & 1966 & 01440000 & Base flow & 5.060 & 0.0272 & No \\
\hline & & & 1981 & 01443500 & Base flow & 13.105 & 0.0005 & Yes \\
\hline & & & 1989 & 01440000 & Base flow & 13.507 & 0.0004 & Yes \\
\hline 01388000 & $1921-2005$ & A & 1927 & 01440000 & Base flow & 18.038 & $<0.0001$ & Yes \\
\hline
\end{tabular}


Table 13. Selected results of analysis of covariance conducted on double-mass curves for 85 streamflow-gaging stations and selected index streamflow-gaging stations on the same stream type in New Jersey.-Continued

[No BP identified, no significant breakpoints were detected on the double-mass curve; --, not applicable; No BP considered, no significant breakpoints were considered for further analysis; No analysis, double-mass analysis was not performed; <, less than]

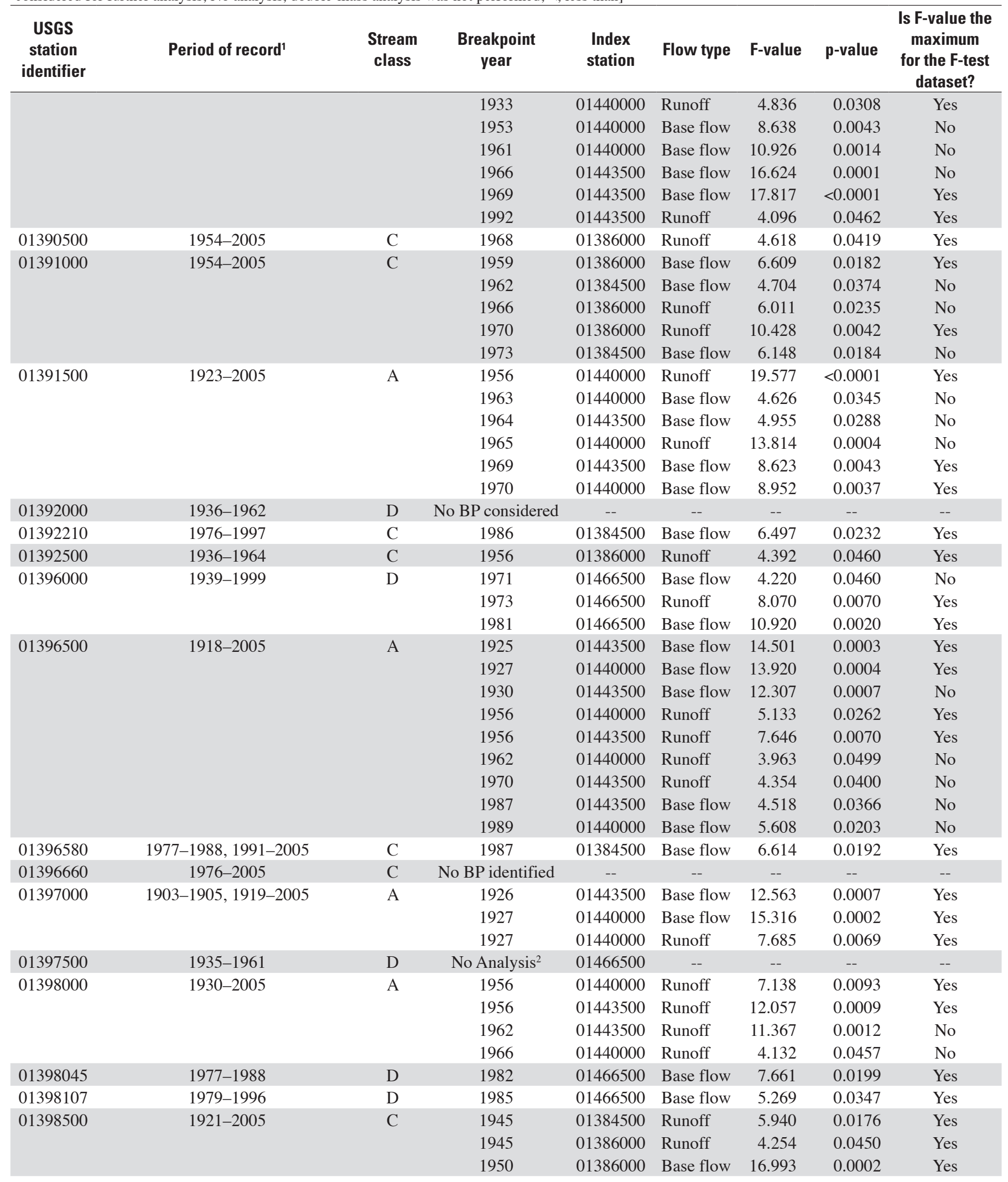


Table 13. Selected results of analysis of covariance conducted on double-mass curves for 85 streamflow-gaging stations and selected index streamflow-gaging stations on the same stream type in New Jersey.-Continued

[No BP identified, no significant breakpoints were detected on the double-mass curve; --, not applicable; No BP considered, no significant breakpoints were considered for further analysis; No analysis, double-mass analysis was not performed; <, less than]

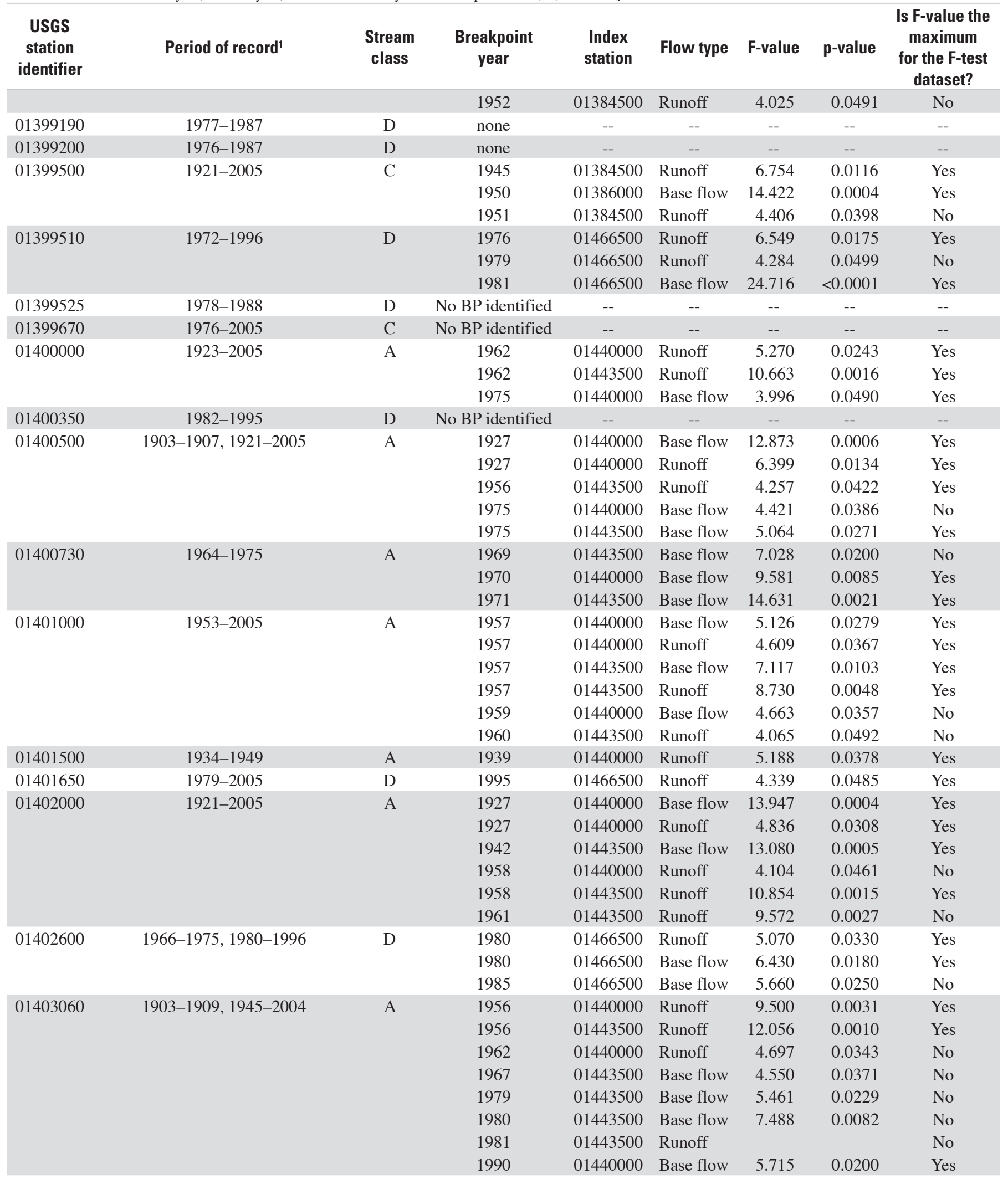


Table 13. Selected results of analysis of covariance conducted on double-mass curves for 85 streamflow-gaging stations and selected index streamflow-gaging stations on the same stream type in New Jersey.-Continued

[No BP identified, no significant breakpoints were detected on the double-mass curve; --, not applicable; No BP considered, no significant breakpoints were considered for further analysis; No analysis, double-mass analysis was not performed; <, less than]

\begin{tabular}{|c|c|c|c|c|c|c|c|c|}
\hline $\begin{array}{c}\text { USGS } \\
\text { station } \\
\text { identifier }\end{array}$ & Period of record ${ }^{1}$ & $\begin{array}{l}\text { Stream } \\
\text { class }\end{array}$ & $\begin{array}{c}\text { Breakpoint } \\
\text { year }\end{array}$ & $\begin{array}{l}\text { Index } \\
\text { station }\end{array}$ & Flow type & F-value & p-value & $\begin{array}{l}\text { Is F-value the } \\
\text { maximum } \\
\text { for the F-test } \\
\text { dataset? }\end{array}$ \\
\hline 01403535 & 1979-2000 & D & 1995 & 01466500 & Runoff & 7.636 & 0.0124 & Yes \\
\hline \multirow[t]{2}{*}{01403540} & 1974-2005 & $\mathrm{D}$ & 1981 & 01466500 & Base flow & 19.221 & 0.0001 & Yes \\
\hline & & & 1995 & 01466500 & Runoff & 4.593 & 0.0406 & Yes \\
\hline \multirow[t]{4}{*}{01408000} & 1931-2005 & A & 1956 & 01440000 & Runoff & 4.644 & 0.0345 & Yes \\
\hline & & & 1956 & 01443500 & Runoff & 7.170 & 0.0092 & Yes \\
\hline & & & 1982 & 01443500 & Base flow & 12.143 & 0.0008 & Yes \\
\hline & & & 1989 & 01440000 & Base flow & 9.299 & 0.0032 & Yes \\
\hline 01408120 & 1972-2005 & A & 1976 & 01443500 & Base flow & 6.500 & 0.0160 & Yes \\
\hline \multirow{3}{*}{01408500} & & & 1942 & 01410000 & Runoff & 6.932 & 0.0103 & Yes \\
\hline & & & 1959 & 01409500 & Base flow & 6.641 & 0.0119 & Yes \\
\hline & & & 1963 & 01409500 & Runoff & 22.542 & $<0.0001$ & Yes \\
\hline \multirow[t]{4}{*}{01409000} & 1931-1958, 1969-1971, 2003-2005 & B & 1941 & 01410000 & Runoff & 5.454 & 0.0266 & No \\
\hline & & & 1958 & 01409500 & Base flow & 7.276 & 0.0115 & Yes \\
\hline & & & 1958 & 01410000 & Runoff & 10.430 & 0.0031 & Yes \\
\hline & & & 1970 & 01409500 & Runoff & 11.189 & 0.0023 & Yes \\
\hline 01409095 & $1966-1985$ & $\mathrm{D}$ & No BP identified & -- & -- & -- & -- & -- \\
\hline 01409280 & $1974-1988$ & $\mathrm{D}$ & 1980 & 01466500 & Base flow & 6.442 & 0.0219 & Yes \\
\hline \multirow[t]{2}{*}{01409400} & 1956-2005 & $\mathrm{B}$ & 1962 & 01409500 & Base flow & 22.940 & $<0.0001$ & Yes \\
\hline & & & 1963 & 01409500 & Runoff & 23.684 & $<0.0001$ & Yes \\
\hline \multirow[t]{4}{*}{01410150} & 1977-2005 & $\mathrm{D}$ & 1988 & 01466500 & Base flow & 15.910 & 0.0005 & No \\
\hline & & & 1993 & 01466500 & Runoff & 4.5856 & 0.0422 & No \\
\hline & & & 1995 & 01466500 & Base flow & 22.717 & $<0.0001$ & Yes \\
\hline & & & 1995 & 01466500 & Runoff & 5.335 & 0.0294 & Yes \\
\hline \multirow[t]{2}{*}{01411000} & 1924-2005 & B & 1931 & 01409500 & Base flow & 4.337 & 0.0407 & Yes \\
\hline & & & 1970 & 01409500 & Runoff & 8.818 & 0.0040 & Yes \\
\hline \multirow[t]{3}{*}{01411300} & 1969-2005 & $\mathrm{C}$ & 1976 & 01384500 & Base flow & 5.830 & 0.0223 & Yes \\
\hline & & & 1978 & 01384500 & Runoff & 7.152 & 0.0122 & Yes \\
\hline & & & 1979 & 01384500 & Base flow & 4.219 & 0.0491 & No \\
\hline 01411456 & 1989-2005 & $\mathrm{D}$ & 1995 & 01466500 & Runoff & 7.847 & 0.0134 & Yes \\
\hline 01411500 & 1932-2005 & $\mathrm{B}$ & 1963 & 01409500 & Runoff & 4.305 & 0.0416 & Yes \\
\hline 01412000 & 1930-1985 & $\mathrm{D}$ & No BP identified & -- & -- & -- & -- & -- \\
\hline 01412800 & 1978-1988 & $\mathrm{C}$ & No BP identified & -- & -- & -- & -- & -- \\
\hline 01437500 & 1937-2005 & A & No BP identified & -- & -- & -- & -- & -- \\
\hline 01440000 & 1924-2005 & A & 1959 & 01443500 & Runoff & 4.582 & 0.0354 & Yes \\
\hline 01443500 & $1921-2005$ & A & No BP considered & -- & -- & -- & -- & -- \\
\hline
\end{tabular}


Table 13. Selected results of analysis of covariance conducted on double-mass curves for 85 streamflow-gaging stations and selected index streamflow-gaging stations on the same stream type in New Jersey.-Continued

[No BP identified, no significant breakpoints were detected on the double-mass curve; --, not applicable; No BP considered, no significant breakpoints were considered for further analysis; No analysis, double-mass analysis was not performed; <, less than]

\begin{tabular}{|c|c|c|c|c|c|c|c|c|}
\hline $\begin{array}{c}\text { USGS } \\
\text { station } \\
\text { identifier }\end{array}$ & Period of record ${ }^{1}$ & $\begin{array}{l}\text { Stream } \\
\text { class }\end{array}$ & $\begin{array}{c}\text { Breakpoint } \\
\text { year }\end{array}$ & $\begin{array}{c}\text { Index } \\
\text { station }\end{array}$ & Flow type & F-value & p-value & $\begin{array}{l}\text { Is F-value the } \\
\text { maximum } \\
\text { for the F-test } \\
\text { dataset? }\end{array}$ \\
\hline 01445000 & 1939-1962 & $\mathrm{C}$ & No BP identified & -- & -- & -- & -- & -- \\
\hline \multirow[t]{2}{*}{01445500} & $1921-2005$ & B & 1962 & 01409500 & Runoff & 4.245 & 0.0428 & No \\
\hline & & & 1972 & 01409500 & Runoff & 9.054 & 0.0036 & Yes \\
\hline \multirow[t]{3}{*}{01446000} & $1922-1961$ & $\mathrm{C}$ & 1939 & 01386000 & Runoff & 5.034 & 0.0329 & Yes \\
\hline & & & 1951 & 01384500 & Runoff & 12.518 & 0.0014 & Yes \\
\hline & & & 1951 & 01386000 & Runoff & 4.727 & 0.0383 & No \\
\hline 01456000 & $1921-1972$ & B & No BP considered & -- & -- & -- & -- & -- \\
\hline 01457000 & 1903-1907, 1921-2005 & B & 1972 & 01409500 & Runoff & 8.457 & 0.0048 & Yes \\
\hline \multirow[t]{3}{*}{01464000} & 1923-2005 & A & 1956 & 01440000 & Runoff & 5.095 & 0.0267 & Yes \\
\hline & & & 1956 & 01443500 & Runoff & 10.852 & 0.0015 & Yes \\
\hline & & & 1961 & 01443500 & Runoff & 9.792 & 0.0024 & No \\
\hline \multirow[t]{2}{*}{01464500} & 1939-2005 & A & 1956 & 01440000 & Runoff & 4.381 & 0.0404 & Yes \\
\hline & & & 1956 & 01443500 & Runoff & 6.386 & 0.0140 & Yes \\
\hline 01465850 & $1962-1975$ & B & & & & & & No \\
\hline 01466000 & $1953-1964$ & $\mathrm{D}$ & 1958 & 01466500 & Runoff & 5.528 & 0.0352 & Yes \\
\hline 01466500 & $1953-2005$ & $\mathrm{D}$ & No BP considered & -- & -- & -- & -- & -- \\
\hline 01467000 & $1921-2005$ & B & 1932 & 01409500 & Runoff & 9.990 & 0.0023 & Yes \\
\hline 01467081 & $1967-2005$ & $\mathrm{C}$ & 1978 & 01384500 & Runoff & 15.447 & 0.0004 & Yes \\
\hline 01475000 & 1940-1976, 2003-2005 & $\mathrm{D}$ & No BP considered & -- & -- & -- & -- & -- \\
\hline 01477120 & $1965-2005$ & $\mathrm{D}$ & No BP identified & -- & -- & -- & -- & -- \\
\hline
\end{tabular}

${ }^{1}$ Indicates water year, which is the 12-month period beginning October 1 and ending September 30 and is named for the year in which it ends.

${ }^{2}$ Analysis was not performed because the period of record of the station and the period of record for the index station for this stream type had less than 10 years of overlap which resulted in less than ten data points for the double-mass curve; this dataset was considered too short for double-mass analysis.

near Bloomsbury (01457000), when related to index station 01410000 (Oswego River at Harrisville), had a significant breakpoint in 1973 when cumulative annual runoff data from 1930 to 1951 were not considered.

The station at South Branch Pennsauken Creek at Cherry Hill (01467081), when related to the index station at Ringwood Creek near Wanaque (01384500), had a breakpoint initially rated as very strong in 1978. There is a gap in the record at station 01384500 from 1978 to 1986, and change in the double-mass slope apparently occurred during those years. Year 1978 was designated as the breakpoint year for the runoff curve for this station, but the strength of the breakpoint was downgraded to moderate because the breakpoint appearance, breakpoint prominence, and slope ratio could not be determined accurately for the period with missing data.

\section{Final Baseline Period Determination}

The final baseline periods for all 85 stations, which were determined by using a combination of historical gage information on the streamflow-gaging station, land-use analysis, and double-mass analysis of annual runoff and base-flow data are listed in table 15 . The steps used to combine the results and determine the baseline period are shown in figure 5. Of 85 stations evaluated, 41 stations had baseline periods that consisted of fewer years than the continuous period of record. Baseline periods of record were reduced primarily by analysis of historical changes in the drainage basin, changes in historical land use, or double-mass analysis. For example, the station at Manasquan River at Squankum (01408000) has a period of record from 1931 to 2005 . Based on historical analysis alone, the baseline period ended in 1989 as a result of expansion of the Manasquan Reservoir in 1990. Statistically significant breakpoints were detected for 1956 on the runoff double-mass curve and for 1982 and 1989 on the base-flow double-mass curve, and it was estimated that 10 percent of the drainage basin was impervious surface in 1997. Since 1956 is the earliest year for which a baseline-period threshold was exceeded and did not compromise the minimum period of record established for stream class A, the baseline period was defined as 1931 to 1956.

For 10 stations, the baseline period was limited in years by change in land use; for 14, by results of double mass analysis; and for 17, by evaluation of historical basin and stream information. Of the 14 stations with a baseline period limited by double-mass analysis, 13 were limited by breakpoints in 
Table 14. Evaluation of breakpoints in double-mass analysis of base-flow and runoff data for selected streamflow-gaging stations in New Jersey.

[BA, numerical score of breakpoint appearance; BP, numerical score of breakpoint prominence; SR, numerical score of slope ratio; BR, numerical score of breakpoint rating $=\mathrm{BP} / \mathrm{BA}+\mathrm{SR} / \mathrm{BA}]$

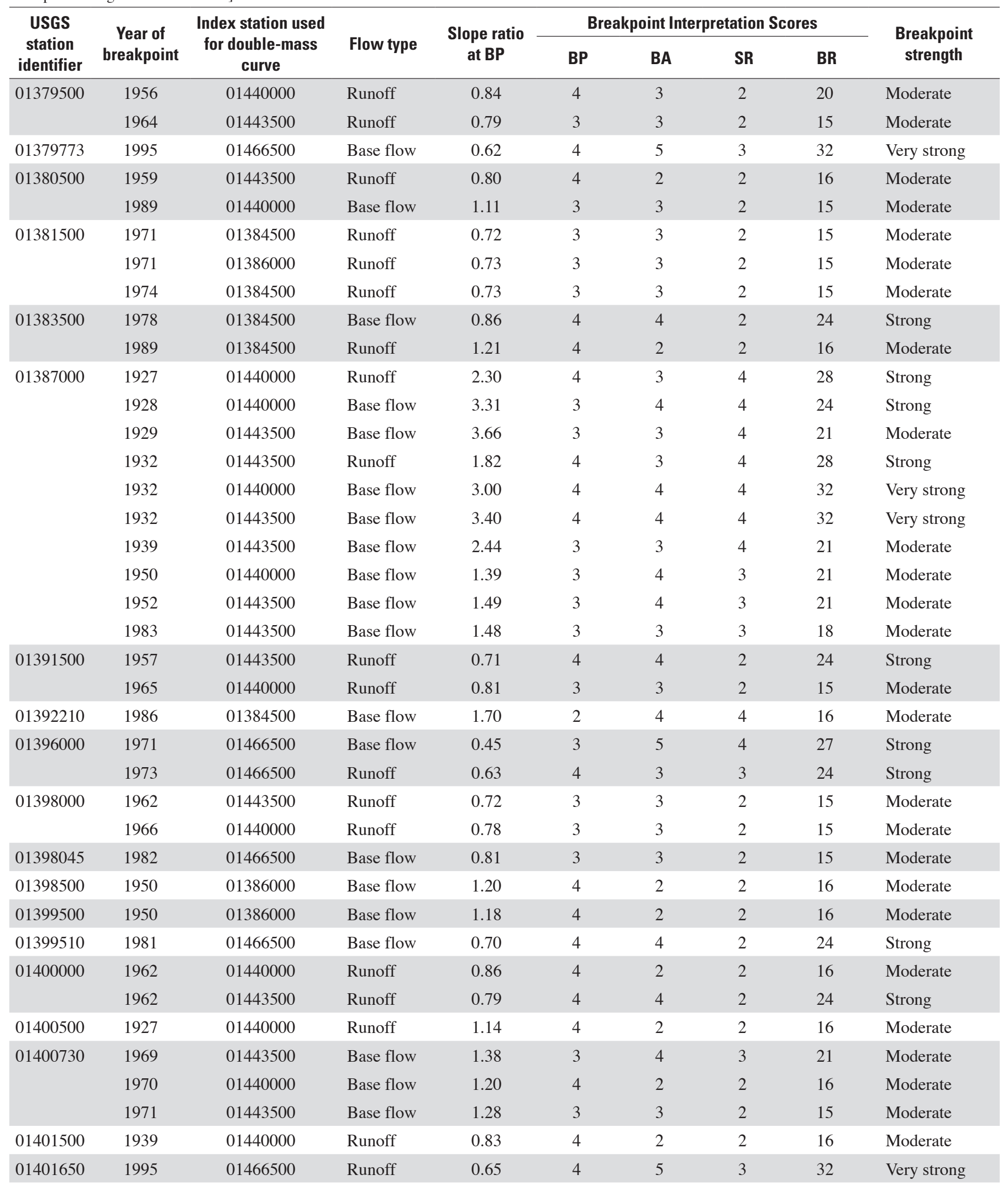


Table 14. Evaluation of breakpoints in double-mass analysis of base-flow and runoff data for selected streamflow-gaging stations in New Jersey.-Continued

[BA, numerical score of breakpoint appearance; BP, numerical score of breakpoint prominence; SR, numerical score of slope ratio; BR, numerical score of breakpoint rating $=\mathrm{BP} / \mathrm{BA}+\mathrm{SR} / \mathrm{BA}]$

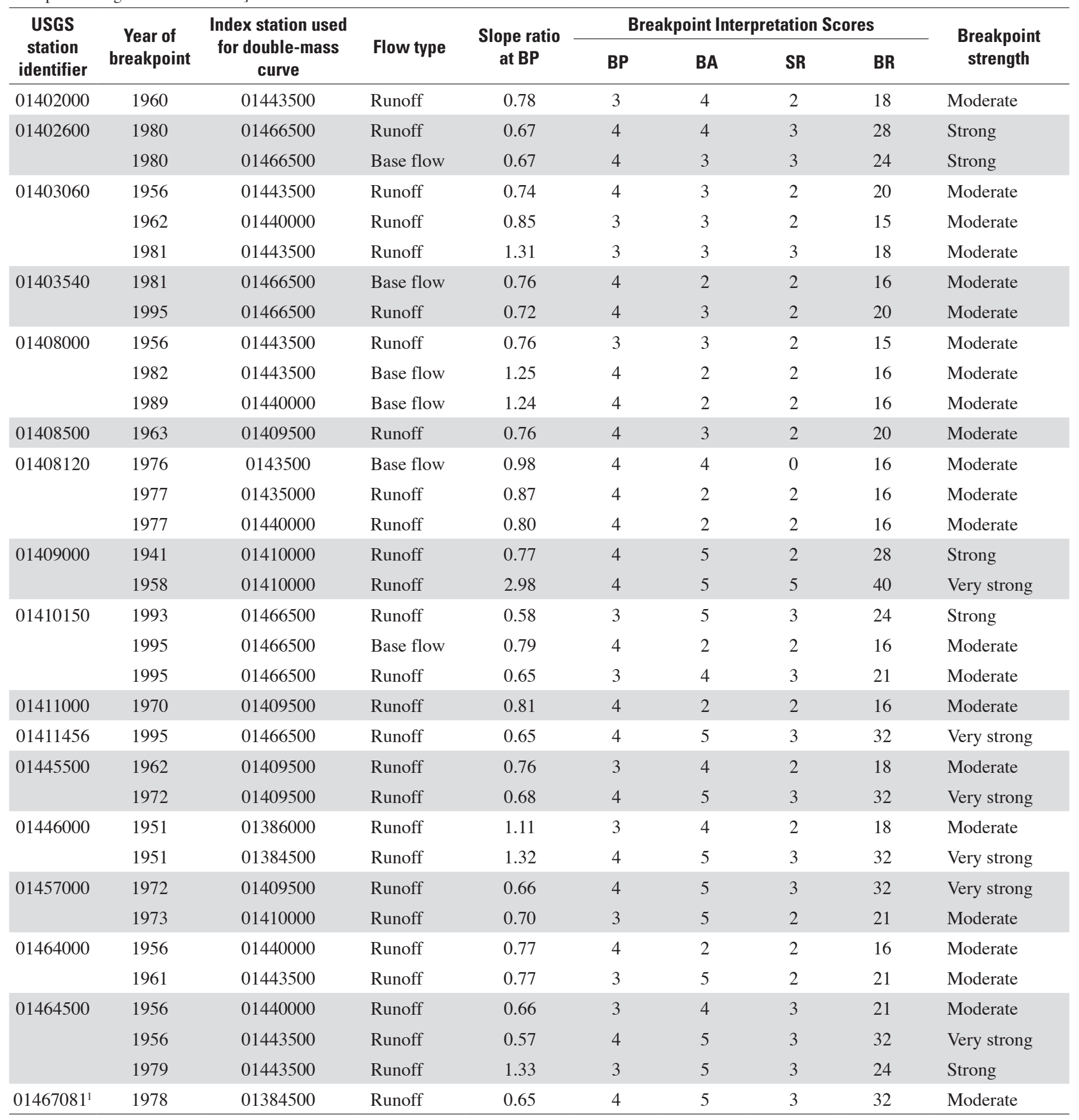

${ }^{1}$ Breakpoint most likely occurred between the years of 1978 and 1986, but exact year could not be determined owing to missing data for the index station. 


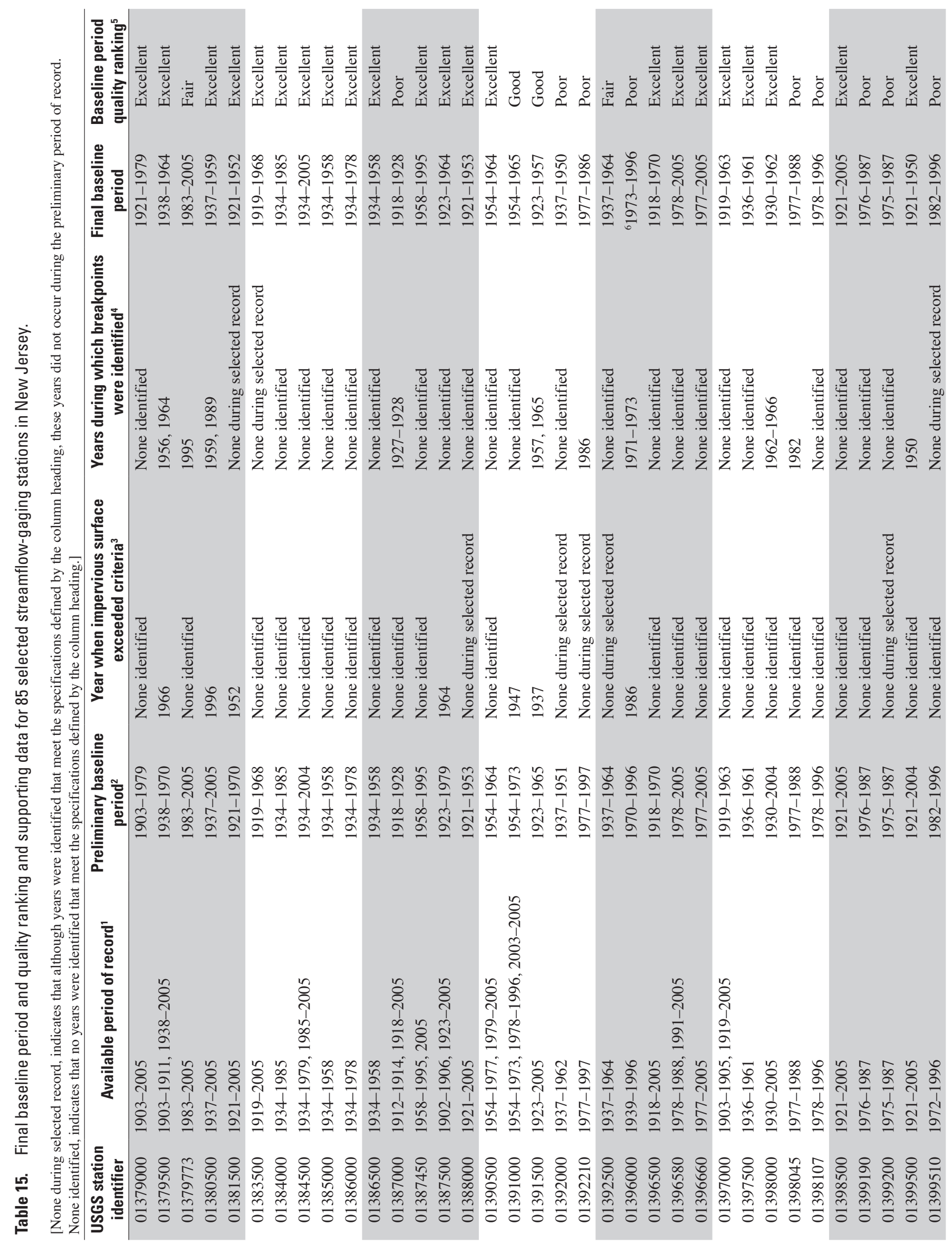




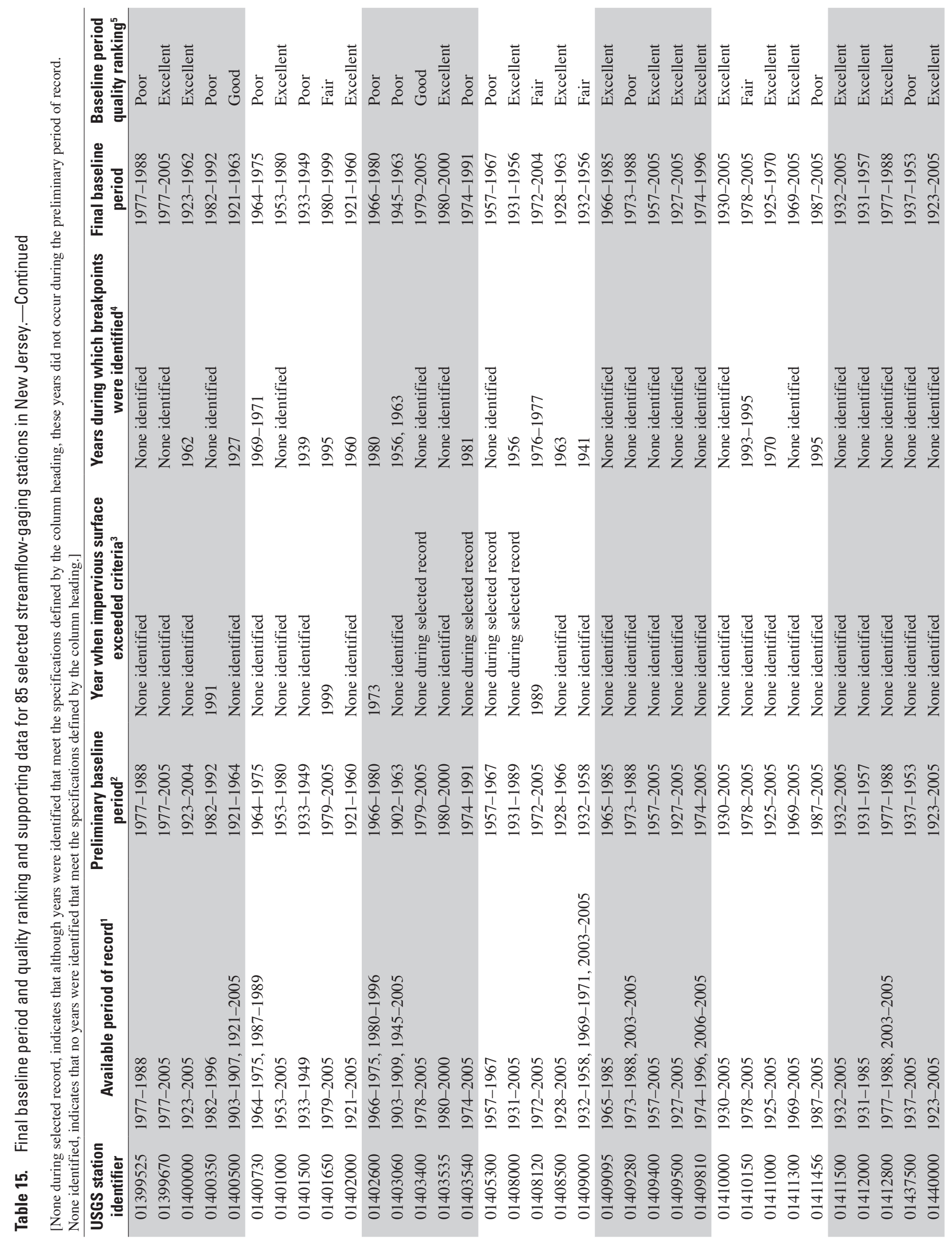




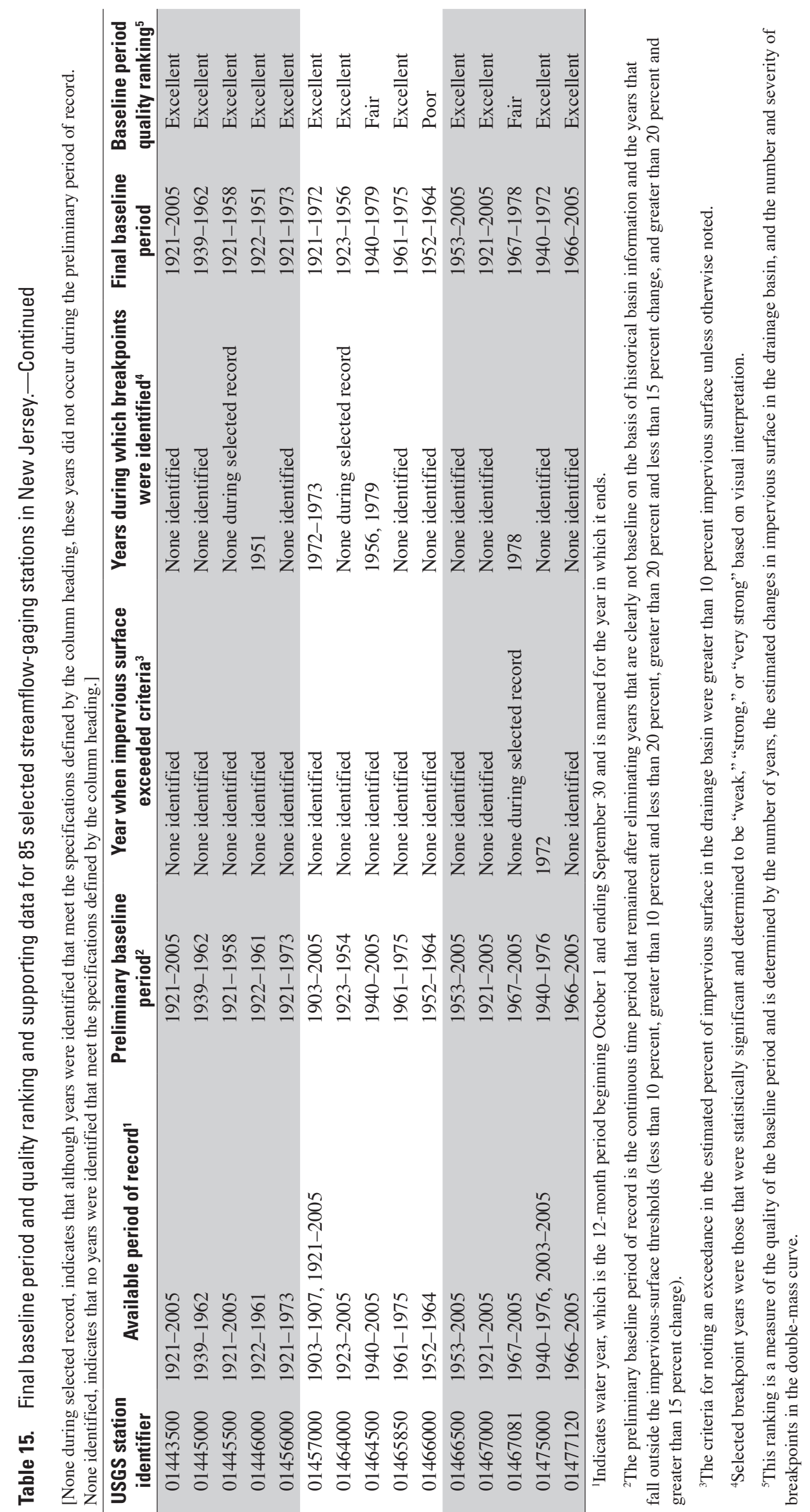


the runoff double-mass curve. The baseline periods of four stations were ended when a threshold was reached after the minimum number of years was achieved. No stations had final baseline periods that crossed three or more thresholds, one station had final baseline periods that crossed two thresholds, and three stations had baselines that crossed one threshold.

Periods of record for several stations were not reduced, although some years in the record did not appear, based on one or more criteria, to be baseline because deleting those years would decrease the record to less than the minimum period of record for the given stream class. A "poor" quality rating was assigned to the baseline period of such stations. The "poor" rated stations, for the purposes of this study, however, are considered the optimal period of record, given the years of continuous streamflow-data available.

Most baseline periods were considered "good" (64 percent); however, final baseline periods of 20 stations were considered "poor" because they contained fewer than the minimum number of years for its stream class. Of those 20 stations, 12 had total periods of record shorter than the required number of years; 6 had baseline periods limited because of historical information; and 4 had baseline periods limited by breakpoints in double-mass curves.

\section{Assumptions and Limitations of Methods Used to Determine Baseline Periods}

Several assumptions were made when determining minimum periods of record for stream classes and baseline periods of record. Relations between impervious surface and population were based on recent data and extrapolated to historical periods. Additionally, the evaluation of double-mass curves included visual assessment of breakpoints, which is subjective by nature.

\section{Historical Land Use/Land Cover}

Historical land use was analyzed to determine a period of record at each station during which urbanization was minimal or unchanging. Urbanization is directly responsible for increases in impervious surface, which leads to increases in stormwater runoff, decreases in base flow, and increases in ground-water withdrawals and surface-water diversions for consumptive purposes (Arnold and Gibbons, 1996; Konrad, 2003; Konrad and Booth, 2002). Previous studies have found that impervious surface levels of 10 to 20 percent cause moderate impairment of hydrologic processes in the basin and greater than 20 percent cause severe impairment (Kennen and Ayers, 2002; Brun and Band, 2000). Therefore, changes resulting from urbanization can compromise the ecological integrity of a stream.
Information on impervious surface was digitally available from the 1995/97 GIS land-use/land-cover coverage (New Jersey Department of Environmental Protection, 2000). In this coverage, Level II land-use information was available for both 1995/97 and 1986, and the percentage of impervious surface for 1986 was estimated on the basis of the relation between land use and impervious surface in the 1995/97 coverage. Following the method of Stankowski (1972), a regression model was developed to relate the mean population density of 570 municipalities in New Jersey to the mean percentage of impervious surface, which was based on digital information from the 1995/97 GIS coverage. The assumption was made that this relation, which reflects more recent patterns of urbanization, would hold constant over time despite changes in building and road-construction patterns. There could be bias in this assumption, however, as a result of changes in patterns of urban development and their relation to impervious surface over the course of the 20th century. For example, the average floor area of new houses has increased from 983 square feet in 1950 to about 2,266 square feet in 2000, whereas average family size decreased over the past 60 years (Diamond and Moezzi, 2004). The results may be that the percentage of impervious surface for earlier years was overestimated, which could explain why Stankowski's 1972 estimate of impervious surface was generally lower than those calculated in this study (fig. 3).

Estimates of the percentage of impervious surface in drainage basins were based on the relation between impervious surface and population density for municipalities, which have different community structures. The difference between the percentage of impervious surface estimated using the regression (equation 2) and the percentage of impervious surface from the 1995/97 GIS coverage for 570 municipalities in New Jersey is shown in figure 6. There is increasing variability in impervious surface for a given population density as population density increases. Also, a linear regression using these two variables results in a slope that is less than 1 . The slope, $\mathrm{r}^{2}$, and standard error of the relation between percentage of impervious surface estimated using a regression model and percentage of impervious surface estimated using GIS data are $0.87,0.84$, and 5.5 , respectively. A plot of the percentage of impervious surface for 85 drainage basins based on the 1995/97 GIS land-use coverage and the percentage of impervious surface for 1996 estimated using the regression model is shown in figure 7. For comparison purposes, an error bar was set at 5.5 units, the standard error of the relation between the two variables for municipalities (shown in figure 7), above and below a one-to-one line. Outliers at higher percentages of impervious surface, most of which are below the one to one line appear to be more extreme than those at lower percentages, indicating that some drainage basins may contain a relatively high proportion of areas of non-residential impervious surface (such as industrial, commercial, military, or transportation areas). This would result in a lower estimate of impervious surface from the regression model as a result of lower population density, but in reality the percentage of impervious 
surface would be greater because of the non-residential land uses. The correction factor (Equation 3) was used to compensate for this variability.

Estimates of historical impervious-surface values are subject to error from several sources, including the relation between population density and impervious surface, incomplete and inaccurate population data, and additional error from the assumption of uniform percentages of Level II land use (and, therefore, impervious surface) throughout the drainage basin where part of the drainage basin lies outside of New Jersey. For the purposes of the baseline study, however, the estimates were considered adequate for determining the period of record with the least degree of human alteration. This is because the change in impervious surface over time was considered more important than the accuracy of the percentage of impervious surface at any point in time. A more in-depth study of historical land-use practices may consider a detailed history of urbanization and other types of development, including historical changes in Level II land use, cultural and socioeconomic factors of development, and changes in agricultural activity in the drainage basin.

The history of agriculture in New Jersey indicates, in general, a decrease in agricultural land use and an increase in urban land use. By 1870, about 3 million of the 4.8 million acres in New Jersey were agricultural. Agriculture in the early 20th century gradually changed from poultry, dairy, and livestock to row crops and nursery products. As urbanization increased, agricultural activity decreased. Agriculture accounted for 36.5 percent of land area in 1930, 37 percent in 1950, 22 percent in 1970, and 17 percent in 1996. Agricultural land may be sold to developers or may be abandoned and undergo natural forest succession. Forested land accounted for 30 percent of New Jersey in 1880, and 32 percent by 1995, according to the 1995/97 land-use coverage (New Jersey Department of Environmental Protection, 2000). Thus there has not been a substantial net loss of forested land in New Jersey in more than 100 years, and urban land use is expanding mostly at the cost of agricultural land use. The transition from agricultural land use to re-forested land use or urban land use is not well defined for the historical time frame of this study, and the historical effects of agricultural land use on hydrology in the basin would have been difficult to predict; therefore, agricultural land use was not considered in the baseline period investigation.

\section{Double-Mass Curves}

The objective of using double-mass analysis was to improve the quality of baseline periods of record by excluding years in which substantial changes in streamflow patterns occurred but were not identified through the evaluation of historical records or population and impervious-surface data. Changes in the slope of the double-mass curve (breakpoints) are assumed to represent changes in streamflow characteristics at the test station that are independent of annual changes in local climate and are the result of changes in land use, regulation, diversion, or other human activity in the basin. In this investigation, an assumption was made that the years before the breakpoint were more representative of baseline conditions than the years after the breakpoint. Therefore, a continuous series of years that met baseline criteria, occurred prior to a breakpoint that was rated moderate or greater, and exceeded the minimum period of record was considered to be the baseline period for that station. In some basins, the early years may not be the best choice of baseline period, especially in areas where stormwater management has been improved, or where former agricultural areas have reverted to forest. Stormwater management, including implementation of retention ponds and catchment basins, can regulate the amount of runoff from precipitation that enters the stream after an event. This may serve to offset the assumed increases in runoff and decreases in base flow that would occur as a result of increases in impervious surface and decreases in native vegetation. Forest canopy and leaf litter from native vegetation help to attenuate runoff by increasing evapotranspiration and reducing runoff. These assumptions reflect the partially subjective nature of determining baseline periods, regardless of the methods and criteria used.

Slope ratios of double-mass curves for the 85 sites are shown as box plots in figure 8 . A one-sided t-test was conducted to determine whether the slope ratios for runoff double-mass curves are less then those of base-flow doublemass curves. Results showed this to be the case $(t=3.60$ with 71 degrees of freedom, probability is greater than 0.999). Additionally, the probability of base-flow slope ratios being greater than 1.0 is 0.98 . and the probability of runoff slope ratios being less than 1.0 is 0.85 . This indicates a trend of increasing runoff and decreasing base flow after a breakpoint, which is consistent with the effects on urbanization of streamflow, where an increase in urbanization can cause an increase in cumulative annual runoff and a decrease in cumulative annual base flow as a result of increases in impervious surface and increases in ground-water and surface-water withdrawals, as was observed by Watson and others (2005) for selected streamflow-gaging stations in New Jersey. Watson and others (2005) also found that urbanization is more strongly related to increasing high-flow values than to decreasing low-flow values.

The abruptness of a breakpoint was an indication of the rate of change in basin dynamics that caused the breakpoint. It is assumed that long-term changes in land use, primarily increases in urbanization or other development, would cause gradual changes in runoff and base-flow patterns, and a curve rather than a sharp bend would be evident in the double-mass curve. A limitation of the analysis of covariance of doublemass curves is that statistically significant breakpoints did not always occur in the same year when a station was tested against two different index stations. Of 45 stations that are classified as stream classes A, B, or C with breakpoints considered for analysis, 19 had breakpoints for the same type of flow (base flow or runoff) that occurred in the same year and 


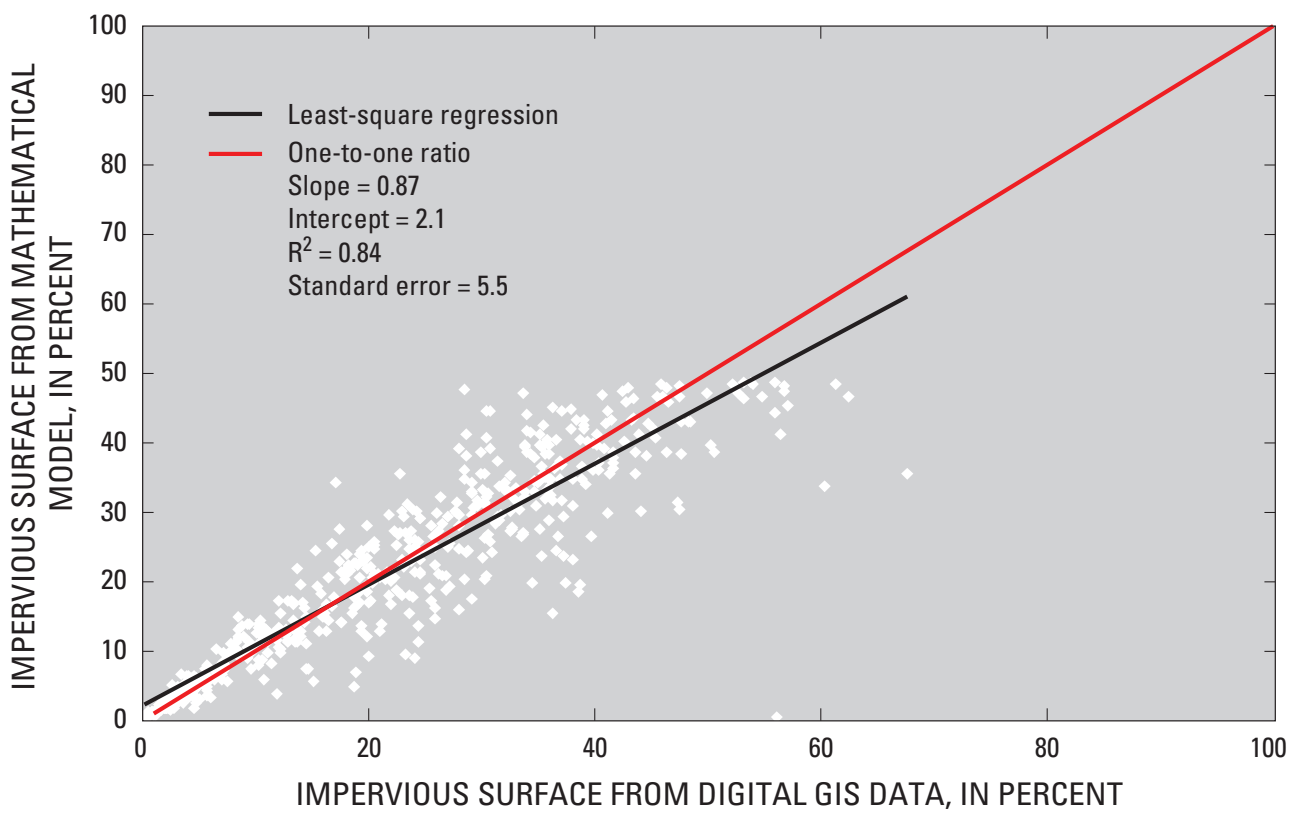

Figure 6. Relation of impervious surface determined from digital geographic information system (GIS) data for 570 municipalities for the years 1995-1997' to impervious surface determined from a mathematical model used to estimate impervious surface using population density for the year 1996. (Spatial impervious surface information, municipality boundaries, and census data ${ }^{2}$ for municipalities were used to derive the relation of percentage of impervious surface and population density data for each municipality.)

${ }^{1}$ Impervious surface data were derived from a digital geographic information system coverage of land use in New Jersey for 1995-1997 (New Jersey Department of Environmental Protection, 2000).

${ }^{2}$ Municipality and population density information are from historic U.S. Census Bureau information for the years 1930-2000 (U.S. Census Bureau, 2007).

6 other stations had breakpoints for the same type of flow that occurred within 3 years of each other. For these stations, of which a total of 55 breakpoints were identified for the same flow type that occurred during the same or similar year when tested against both index stations, only 19 breakpoints (among 11 stations) were considered moderate or stronger. One possible explanation is that one or both of the index stations used in the double-mass curve may not have been appropriate for the test station. It was assumed for this investigation, however, that double-mass curves of index stations and test stations of the same stream class should be linear without breakpoints in the absence of hydrologic changes in the test station basin, even though stream class is based solely on similarities and differences in selected hydrologic indices, not on hydrogeology, precipitation, soil type, or other physical factors that can affect streamflow.

Poor correlation between the test station and index station could hinder detection of the breakpoint using the analysis of covariance test. Although index stations were compared to test sites of the same stream class, the comparison does not ensure that the sites are hydrologically similar. A difference in precipitation patterns between geographically distant sites could produce poorly correlated double-mass curves in which line segments would have substantial scatter and breakpoints would be difficult to detect. For example, a test station and index station that are the same stream class but are located in different climate zones could receive substantially different precipitation amounts.

Given the assumptions and observations mentioned above, double-mass analysis alone could not be used to identify baseline periods. The method, as used in this investigation, combines objective, statistically based screening with subjective observation and analysis. The double-mass analysis results were used only to reduce the number of years considered as baseline while maintaining a minimum period of record or to assign a qualitative ranking to the baseline period. 


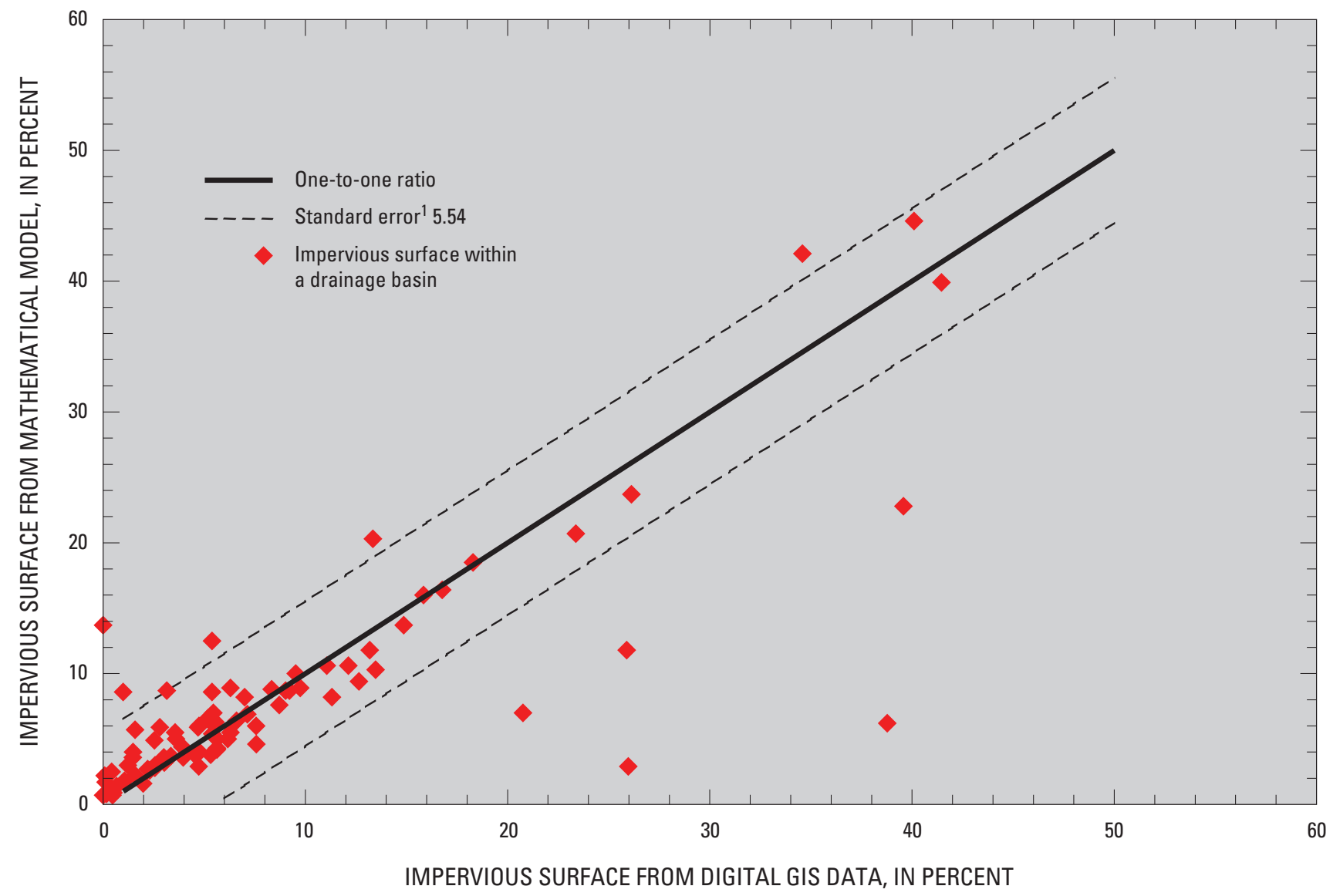

Figure 7. Relation of impervious surface determined from digital geographic information system (GIS) data for 85 drainage basins for the years 1995-1997 to impervious surface determined from mathematical model based on population density for the year 1996, for the same 85 drainage basins in New Jersey. (Spatial impervious surface information ${ }^{2}$ and drainage basin boundaries ${ }^{3}$ were used to derive the percentage of impervious surface for each drainage basin. Spatial census block data ${ }^{4}$ and drainage basin boundaries were used to derive the population density for each drainage basin.)

${ }^{1}$ Standard error is from least-squares regression for the relation between the percentage of impervious surface for drainage basins determined from GIS information (1995-1997) and from a mathematical model, and in this graph is set about the one-to-one line.

${ }^{2}$ Impervious surface data were derived from a digital geographic information system coverage of land use in New Jersey for1995-1997 (New Jersey Department of Environmental Protection, 2000).

${ }^{3} \mathrm{~A}$ geographic information systems coverage of drainage basins for 85 surface-water gaging stations was developed from drainage basin delineations using a 30-meter-grid digital elevation model coverage of New Jersey.

${ }^{4}$ Population density information for drainage basins was derived from a digital geographic information system coverage of spatial census block information for the years 1930-2000, using historic information from the U.S. Census Bureau (U.S. Census Bureau, 2007). 


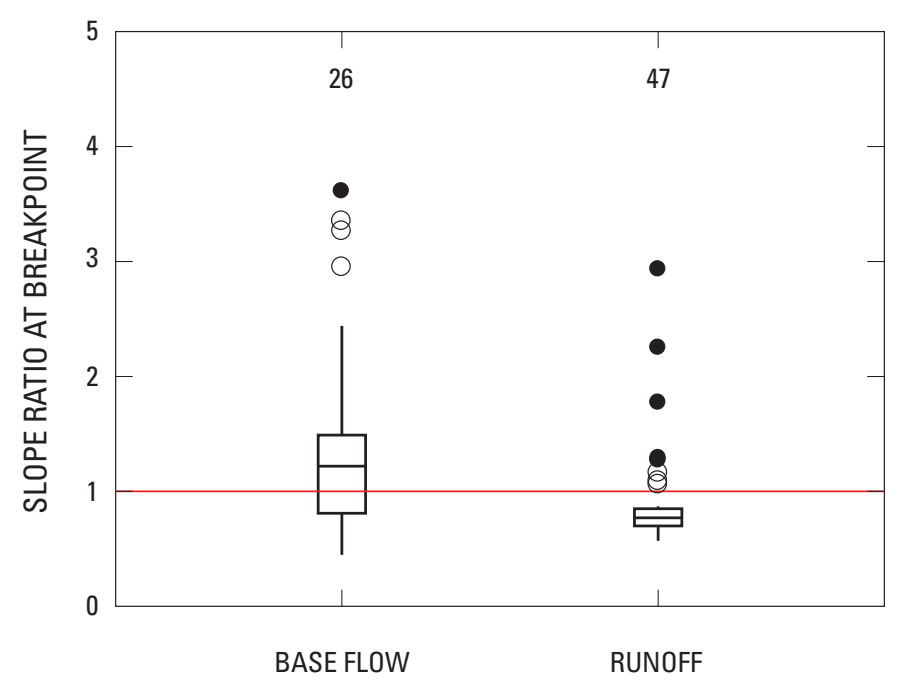

EXPLANATION

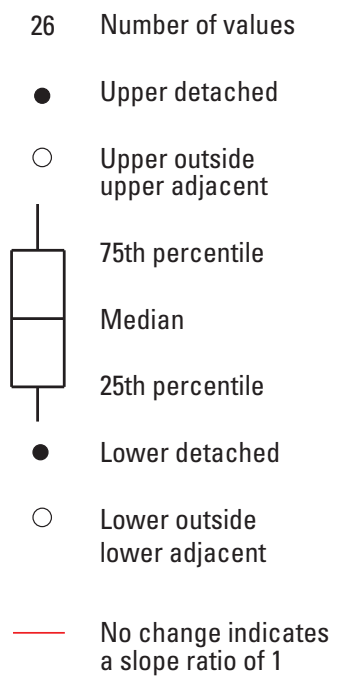

Figure 8. Boxplot showing slope ratios at selected statistically significant breakpoints on the double-mass curve for test stations and index stations.

(Slope ratios are the ratio of cumulative annual flow at the test station divided by cumulative annual flow at the index station at selected breakpoint years. Slope ratios greater than 1 indicate an increase in slope at the test station and values less than 1 indicate a decrease in slope at the test station. "No change" line indicates a slope of 1.0)

\section{Summary and Conclusions}

Characteristics of streamflow, which can be represented by environmentally relevant hydrologic indices (ERHIs), are known to affect the integrity of aquatic ecological systems. Many of these indices have been identified in previous research. The aspects of the flow regime considered when determining the indices include magnitude, duration, fre- quency, and rate of change, and the timing from the daily hydrograph.

Continuous daily streamflow data from 85 automated streamflow-gaging stations in New Jersey were used to compute hydrologic indices. To compute the hydrologic indices, an optimum baseline period of record for each station was determined from the available record of continuous daily streamflow data that reflects a period when the streamflow was the least altered by human activity.

The minimum number of years for a baseline period was determined by testing the null hypothesis of no difference among ERHIs calculated for sequential periods of 5, 10,15 , and 20 years by using the Kruskall-Wallis test. If the years considered for baseline status after analysis of historical streamflow information amounted to less than that minimum period, which varies among the four stream classes, the baseline period was rated "poor."

Urbanization and population growth in New Jersey has increased substantially over the past century, but rates of development vary among basins. Therefore, the baseline period as defined in this investigation may vary in quality. Each baseline period was ranked as "excellent," "good," "fair," or "poor," the rank denotes stability of the period of record selected for baseline status with respect to changes in the basin that affect streamflow characteristics.

Years during which stations had substantial regulation, large diversions of flow, major ground-water or surface-water withdrawals from the drainage basins, or extensive urbanization were excluded from baseline periods. This information was gathered from documented streamflow-gaging station data and information from the USGS News Jersey Water Science Center staff. Additional methods were used to supplement analysis for years when no known historical changes in the stream reach had occurred, or minor activity had occurred, but the best period of record could not be selected from the streamflow-gaging station data alone. Land use in the drainage basin and changes in annual runoff and base flow were estimated for the selected stations in order to improve the baseline period.

Historic trends in urbanization were evaluated using population data and the relation between population growth and impervious surface. Impervious surface was used as an indictor for the baseline period because it has a direct effect on rates of runoff and base flow, and increases in impervious surface are related to other effects of urbanization, including increased ground-water and surface-water withdrawals for consumption. Impervious surface and other specific land-use information, in general, were not available for years prior to 1986; therefore, population density was used to estimate impervious surface for those years. Variability in the estimates probably was the result of differences in population growth and development, such as construction of industrial or commercial development, which may or may not include residential areas.

Changes in trends of annual runoff and base flow were determined by using analysis of covariance of double-mass 
curves. Double-mass curves consist of a plot of cumulative data, in this case cumulative annual runoff and base flow, between the test station (x-axis) and index station (y-axis). Changes in annual runoff or base flow depicted on this curve were assumed to result from changes in the test station and not from periodic climate variation or changes in the annual streamflow characteristics at the index station. It was assumed that changes in annual runoff or base flow at the test station resulted from a change in annual streamflow characteristics and that the earlier period of record (before the suspected change occurred) was better suited for a baseline period. Statistically significant breakpoints on the double-mass curve for the period of record were evaluated using analysis of covariance to test the null hypothesis of no difference between the slope of the regression line before and the slope after the breakpoint. In addition, breakpoints were visually evaluated for strength and magnitude. A numerical rating system then was used to give each breakpoint an overall rating of "very strong," "strong," "moderate," or "weak."

Results from all three baseline determination criteria then were used to select the final baseline period. Index values for all 171 indices were calculated for the baseline period and presented on the USGS World Wide Web site at http://(website construction in progress).gov.

Hydrologic indices can be used in regulatory planning to establish streamflow standards that encompass ecological integrity as a management goal in riverine resources. Indices calculated from daily streamflow data from a period when human activities in the drainage basin were minimal, a time when the local aquatic ecological system was functioning in a relatively more natural state, can be used to establish more comprehensive streamflow standards and requirements than are currently available.

\section{References Cited}

Alley, W.M., and Veenhuis, J.E., 1983, Effective impervious area in urban runoff modeling: Journal of Hydraulic Engineering-Asce, v. 109, no. 2, p. 313-319.

Anderson, J.R., Hardy, E.E., Roach, J.T., and Witmer, R.E., 1976, A land use and land cover classification system for use with remote sensor data: U.S. Geological Survey Professional Paper 964, 28 p.

Arnold, C.L., and Gibbons, C.J., 1996, Impervious surface coverage: The emergence of a key environmental indicator: Journal of the American Planning Association, v. 62, p. 243.

Ayers, M.A., Kennen, J.G., and Stackelberg P.E., 2000, Water quality in the Long Island-New Jersey coastal drainages, New York and New Jersey, 1996-98: U.S. Geological Survey Circular 1201, 40 p.
Bauersfeld, W.R., Moshinsky, E.W., and Gurney, C.E., 1995, Water Resources Data, New Jersey, Water Year 1994, v. 1, Surface-Water Data: U.S. Geological Survey Water-Data Report NJ-94-1, 559 p.

Bauersfeld, W.R., Moshinsky, E.W., and Gurney, C.E.,1993, Water Resources Data, New Jersey, Water Year 1992, v. 1, Surface-Water Data: U.S. Geological Survey Water-Data Report NJ-92-1, 507 p.

Bauersfeld, W.R., Moshinsky, E.W., and Gurney, C.E.,1994, Water Resources Data, New Jersey, Water Year 1993, v. 1, Surface-Water Data: Water-Data Report NJ-93-1, 503 p.

Bauersfeld, W.R., Moshinsky, E.W., and Pustay, E.A., 1991, Water Resources Data, New Jersey, Water Year 1990, v. 1, Surface-Water Data: U.S. Geological Survey Water-Data Report NJ-90-1, 436 p.

Bauersfeld, W.R., Moshinsky, E.W., and Pustay, E.A., 1992, Water Resources Data, New Jersey, Water Year 1991, v. 1, Surface-Water Data: U.S. Geological Survey Water-Data Report NJ-91-1, 496 p.

Bauersfeld, W.R., Moshinsky, E.W., Pustay, E.A., and Jones, W.D., 1990, Water Resources Data for New Jersey, Water Year 1989, v. 1, Atlantic Slope Basins; Hudson River to Cape May: U.S. Geological Survey Water-Data Report NJ-89-1, 345 p.

Bauersfeld, W.R., Moshinsky, E.W., Pustay, E.A., and Jones, W.D., 1990, Water Resources Data for New Jersey, Water Year 1989, v. 2, Delaware River Basin and Tributaries to Delaware Bay: U.S. Geological Survey Water-Data Report NJ-89-2, 215 p.

Bauersfeld, W.R., Moshinsky, E.W., Pustay, E.A., and Jones, W.D., 1989, Water Resources Data for New Jersey, Water Year 1988, v. 1, Atlantic Slope Basins; Hudson River to Cape May: U.S. Geological Survey Water-Data Report NJ-88-1, 359 p.

Bauersfeld, W.R., Moshinsky, E.W., Pustay, E.A., and Jones, W.D., 1989, Water Resources Data for New Jersey, Water Year 1988, v. 2, Delaware River Basin and Tributaries to Delaware Bay: U.S. Geological Survey Water-Data Report NJ-88-2, 217 p.

Bauersfeld, W.R., Moshinsky, E.W., Pustay, E.A., and Jones, W.D., 1988, Water Resources Data for New Jersey, Water Year 1987, v. 1, Atlantic Slope Basins; Hudson River to Cape May: U.S. Geological Survey Water-Data Report NJ-87-1 347 p.

Bauersfeld, W.R., Moshinsky, E.W., Pustay, E.A., and Jones, W.D., 1988, Water Resources Data for New Jersey, Water Year 1987, v. 2, Delaware River Basin and Tributaries to Delaware Bay: U.S. Geological Survey Water-Data Report NJ-87-2, 199 p. 
Bauersfeld, W.R., Moshinsky, E.W., Pustay, E.A., and Jones, W.D., 1987, Water Resources Data for New Jersey, Water Year 1986, v. 1, Atlantic Slope Basins; Hudson River to Cape May: U.S. Geological Survey Water-Data Report NJ-86-1, 335 p.

Bauersfeld, W.R., Moshinsky, E.W., Pustay, E.A., and Jones, W.D., 1987, Water Resources Data for New Jersey, Water Year 1986, v. 2, Delaware River Basin and Tributaries to Delaware Bay: U.S. Geological Survey Water-Data Report NJ-86-2, 197 p.

Bauersfeld, W.R., Moshinsky, E.W., Pustay, E.A., and Jones, W.D., 1986, Water Resources Data for New Jersey, Water Year 1985, v. 1, Atlantic Slope Basins; Hudson River to Cape May: U.S. Geological Survey Water-Data Report NJ-85-1, 319 p.

Bauersfeld, W.R., Moshinsky, E.W., Pustay, E.A., and Jones, W.D., 1986, Water Resources Data for New Jersey, Water Year 1985, v. 2, Delaware River Basin and Tributaries to Delaware Bay: U.S. Geological Survey Water-Data Report NJ-85-2, $191 \mathrm{p}$.

Bauersfeld, W.R., Moshinsky, E.W., Pustay, E.A., and Schaefer, F.L., 1985, Water Resources Data for New Jersey, Water Year 1984, v. 1, Atlantic Slope Basins; Hudson River to Cape May: U.S. Geological Survey Water-Data Report NJ-84-1, 327 p.

Bauersfeld, W.R., Moshinsky, E.W., Pustay, E.A., and Schaefer, F.L., 1985, Water Resources Data for New Jersey, Water Year 1984, v. 2, Delaware River Basin and Tributaries to Delaware Bay: U.S. Geological Survey Water-Data Report NJ-84-2, 184 p.

Bauersfeld, W.R., Moshinsky, E.W., Pustay, E.A., and Schaefer, F.L., 1984, Water Resources Data for New Jersey, Water Year 1983, v. 1, Atlantic Slope Basins; Hudson River to Cape May: Water-Data Report NJ-83-1, 320 p.

Bauersfeld, W.R., Moshinsky, E.W., Pustay, E.A., and Schaefer, F.L., 1984, Water Resources Data for New Jersey, Water Year 1983, v. 2, Delaware River Basin and Tributaries to Delaware Bay: U.S. Geological Survey Water-Data Report NJ-83-2, 195 p.

Bauersfeld, W.R., Moshinsky, E.W., Pustay, E.A., and Schaefer, F.L., 1983, Water Resources Data for New Jersey, Water Year 1982, v. 1, Atlantic Slope Basins; Hudson River to Cape May: U.S. Geological Survey Water-Data Report NJ-82-1, 329 p.

Bauersfeld, W.R., Moshinsky, E.W., Pustay, E.A., and Schaefer, F.L., 1983, Water Resources Data for New Jersey, Water Year 1982, v. 2, Delaware River Basin and Tributaries to Delaware Bay: Water-Data Report NJ-82-2, 209 p.
Brun, S.E., Band, L.E., 2000, Simulating runoff behavior in an urbanizing basin: Computers, environment and urban systems, v. 24, p. 5-22.

Centinaro, G.L., White, B.T., Hoppe, H.L., Dudek, J.F., Protz, A.R., Reed, T.J., Shvanda, J.C., and Watson, A.F., 2005, Water resources data, New Jersey, water year 2004, v. 1, Surface-water data: U.S. Geological Survey Water-Data Report NJ-04-1, 412 p.

Centinaro, G.L., White, B.T., Hoppe, H.L., Dudek, J.F., Protz, A.R., Reed, T.J., Shvanda, J.C., and Watson, A.F., 2004, Water resources data, New Jersey, water year 2004, v. 1, Surface-water data: US Geological Survey Water Data Report NJ-04-01.

Diamond, R., and Moezzi, M., 2004, Changing trends: A brief history of the U.S. consumption of energy, water, beverage and tobacco, in Summer study on energy efficiency in buildings, American Council for an Energy Efficient Economy, Washington, D.C., August 22 - 27, 2004, Proceedings: Pacific Grove, California, Asilomar Conference Center, v. 10, p. 1-12.

Field, L.Y., 1997, Best management practices for soil erosion: West Lafayette, LA, Purdue Research Foundation, accessed January 23, 2007, at http://cobweb.ecn.purdue.edu/ epados/ erosbmp/src/credits.htm.

Fitzpatrick, F.A., Knox, J.C., and Whitman, H.E., 1999, Effects of historical land-cover changes on flooding and sedimentation, North Fish Creek, Wisconsin: U.S. Geological Survey Water-Resources Investigations Report 99-4083, $12 \mathrm{p}$.

Kennen, J.G., and Ayers, M.A., 2002, Relation of environmental characteristics to the composition of aquatic assemblages along a gradient of urban land-use in New Jersey, 1996-98: Water-Resources Investigations Report 02-4069, 77 p.

Konrad, C.P., 2003, Effects of urban development on floods: U.S. Geological Survey Fact Sheet 076-03, 4 p.

Konrad, C.P., and Booth, D.B., 2002, Hydrologic trends associated with urban development for selected streams in the Puget Sound basin, western Washington: U.S. Geological Survey Water-Resources Investigations Report 02-4040, $40 \mathrm{p}$.

New Jersey Department of Environmental Protection, 2000, 1995/97 Landuse/Landcover by Basin Management Area (WMA): Trenton, N.J., accessed March 15, 2006, at http:// www.state.nj.us/dep/dsr/map-integration/LULC95.htm.

New Jersey Department of Environmental Protection, 2007, Physiographic provinces of New Jersey, accessed April 24, 2007, at http://www.njgeology.org/enviroed/infocirc/provinces.pdf. 
New Jersey Department of Environmental Protection, 2008, Priorities and action plan: Trenton, N.J., accessed January 4, 2008, at http://www.nj.gov/dep/commissioner/docs/priorities_and_action_plan2007.pdf.

Office of the New Jersey State Climatologist, Rutgers, The State University of New Jersey, Monthly and annual statewide data (1895-Present), accessed July 6, 2005, at http:// climate.rutgers.edu/stateclim/.

Olden, J.D., and Poff, N.L., 2003, Redundancy and the choice of hydrologic indices for characterizing streamflow regimes: River Research and Applications, v. 19, p. 101-121.

Pettyjohn, W.A., and Henning, R.J., 1979, Preliminary estimate of ground-water recharge rates, related streamflow and water quality in Ohio: Columbus, Ohio, Ohio State University Water Resources Center Project Completion Report Number 552, 323 p.

Poff, N.L., 1996, A hydrogeography of unregulated streams in the United States and an examination of scale-dependence in some hydrological descriptors: Freshwater Biology, v. 36, p. 71-91.

Poff, N.L., Allan, J.D., Bain, M.B., Karr, J.R., Prestegaard, K.L., Richter, B.D., Sparks, R.E., and Stromberg, J.C., 1997, The natural flow regime: A new paradigm for riverine conservation and restoration: BioScience, v. 47, p. 769-784.

Poff, N.L., and Ward, J.V., 1989, Implications of streamflow variability and predictability for lotic community structure: A regional analysis of streamflow patterns: Canadian Journal of Fisheries and Aquatic Sciences, v. 46, p. 1805-1818.

Reed, T.J., Centinaro, G.L., DeLuca, M.J., Hutchinson, J.T., and Scudder, J., 1997, Water Resources Data, New Jersey, Water Year 1996, v. 1, Surface-Water Data: U.S. Geological Survey Water-Data Report NJ-96-1, 562 p.

Reed, T.J., Centinaro, G.L., DeLuca, M.J., and Oden, J.H., 1998, Water Resources Data, New Jersey, Water Year 1997, v. 1, Surface-Water Data: U.S. Geological Survey WaterData Report NJ-97-1, 608 p.

Reed, T.J., Centinaro, G.L., Dudek, J.F., Corcino, V., and Steckroat, G.C., 2001, Water Resources Data, New Jersey, Water Year 2000, v. 1, Surface-Water Data: U.S. Geological Survey Water-Data Report NJ-00-1, 233 p.

Reed, T.J., Centinaro, G.L., Dudek, J.F., Corcino, V., and Steckroat, G.C., 2000, Water Resources Data, New Jersey, Water Year 1999, v. 1, Surface-Water Data: U.S. Geological Survey Water-Data Report NJ-99-1, 293 p.

Reed, T.J., DeLuca, M.J., Centinaro, G.L., and Hutchinson, J.T., 1996, Water Resources Data, New Jersey, Water Year 1995, v. 1, Surface-Water Data: U.S. Geological Survey Water-Data Report NJ-95-1, 562 p.
Reed, T.J., White, B.T., Centinaro, G.L., Dudek, J.F., Corcino, V., Spehar, A.B., and Protz, A.R., 2002, Water Resources Data, New Jersey, Water Year 2001, v. 1, Surface-Water Data: U.S. Geological Survey Water-Data Report NJ-01-1, 297 p.

Reed, T.J., White, B.T., Centinaro, G.L., Dudek, J.F., Protz, A.R., Shvanda, J.C., and Watson, A.F., 2004, Water Resources Data, New Jersey, Water Year 2003, v. 1, Surface-Water Data, U.S. Geological Survey Water-Data Report NJ-03-1, 388 p.

Reed, T.J., White, B.T., Centinaro, G.L., Dudek, J.F., Spehar, A.B., Protz, A.R., Shvanda, J.C., Watson, A.F., and Holzer, G.K., 2003, Water Resources Data, New Jersey, Water Year 2002, v. 1, Surface-Water Data, U.S. Geological Survey Water-Data Report NJ-02-1, 391 p.

Richter, B.D., Baumgartner, J.V., Wiginton, R., and Braun, D.P., 1997, How much water does a river need?: Freshwater Biology, v. 37, p. 231-249.

Schueler, T.R., 1994, The Importance of imperviousness: Watershed protection techniques, v. 1, no. 3, p.100-111.

Searcy, J.K., and Hardison, C.H., 1960, Double-mass curves: U.S. Geological Survey Water-Supply Paper 1541-B, 66 p.

Sloto, R.A., and Crouse, M.Y., 1996, HYSEP: A computer program for streamflow hydrograph separation and analysis: U.S. Geological Survey Water-Resources Investigations Report 96-4040, 46 p.

Smith, L.I., 2003, A tutorial on principle component analysis: Ithaca, NY, Cornell University, accessed Feb. 26, 2006, at http://csnet.otago.ac.nz/cosc453/student_tutorials/principal_components.pdf.

Snedecor, G.W., 1934, Calculation and interpretation of analysis of variance and covariance: Ames, Iowa, Collegiate Press, $96 \mathrm{p}$.

Stankowski, S.J., 1972, Population density as an indirect indicator of urban and suburban land-surface modifications: U.S. Geological Survey Professional Paper 800B, p. 219-224.

U.S. Census Bureau, 2000, United States Census 2000: U.S. Census Bureau, accessed August 3, 2005, at http://www. census.gov/main/www/cen2000.html.

U.S. Census Bureau, 2005, Statistical abstracts of the United States, resident population, states, 1980-2003: U.S. Census Bureau, accessed July 26, 2005, at http://www.census.gov/ prod/www/statistical-abstract-04.html.

U.S. Geological Survey, 1936, Surface Water Supply of New Jersey Streamflow Records October, 1928 to September, 1934: Trenton, N.J., State of N.J. Special Report 5, 253 p. 
U.S. Geological Survey, 1944, Surface Water Supply of New Jersey Streamflow Records October, 1934 to September, 1940: Trenton, N.J., State of N.J. Special Report 9, 444 p.

U.S. Geological Survey, 1952, Surface Water Supply of New Jersey Streamflow Records October, 1940 to September, 1945: Trenton, N.J., State of N.J. Special Report 12, 379 p.

U.S. Geological Survey, 1959, Surface Water Supply of New Jersey Streamflow Records October, 1945 to September, 1950: Trenton, N.J., State of N.J. Special Report 14, 362 p.

U.S. Geological Survey, 1960, Surface Water Supply of New Jersey Streamflow Records October, 1950 to September, 19550: Trenton, N.J., State of N.J. Special Report 16, 405 p.

U.S. Geological Survey, 1963, Surface Water Supply of New Jersey Streamflow Records October, 1955 to September, 1960: Trenton, N.J., State of N.J. Special Report 20, 425 p.

U.S. Geological Survey, 1965, Water-resources data for New Jersey, 1965, Part1, Surface Water Records, 38 p.

U.S. Geological Survey, 1967, Water-resources data for New Jersey, 1967, Part 1. Surface Water Records, 152 p.

U.S. Geological Survey, 1968, Surface Water Supply of New Jersey Streamflow Records October, 1960 to September, 1965: Trenton, N.J., State of N.J. Special Report 31, 351 p.

U.S. Geological Survey, 1968, Water-resources data for New Jersey, 1968, Part 1. Surface Water Records, 143 p.

U.S. Geological Survey, 1970, Water-resources data for New Jersey, 1969, Part 1. Surface Water Records, 157 p.

U.S. Geological Survey, 1971, Water-resources data for New Jersey, 1970, Part 1. Surface Water Records, 170 p.

U.S. Geological Survey, 1972, Water-resources data for New Jersey, 1971, Part 1. Surface Water Records: Water Data Report NJ-71-1, 183 p.

U.S. Geological Survey, 1973, Water-resources data for New Jersey, 1972, Part 1. Surface Water Records: Water Data Report NJ-72-1, 163 p.

U.S. Geological Survey, 1974, Water-resources data for New Jersey, 1973, Part 1. Surface Water Records: Water Data Report NJ-73-1, 183 p.

U.S. Geological Survey, 1975, Water-resources data for New Jersey, 1974, Part 1. Surface Water Records: Water Data Report NJ-74-1, 185 p.

U.S. Geological Survey, 1976, Water-resources data for New Jersey, water years 1975: Water Data Report NJ-75-1, $474 \mathrm{p}$.
U.S. Geological Survey, 1977, Water-resources data for New Jersey, water years 1976: Water Data Report NJ-76-1, 811 p.

U.S. Geological Survey, 1977, Water-resources data for New Jersey, water years 1977, v. 1, Atlantic Slope Basins; Hudson River to Cape May: Water Data Report NJ-77-1, 491 p.

U.S. Geological Survey, 1977, Water-resources data for New Jersey, water years 1977, v. 2, Delaware River Basin and tributaries to Delaware Bay: Water Data Report NJ-77-2, $325 \mathrm{p}$.

U.S. Geological Survey, 1978, Water-resources data for New Jersey, water years 1978, v. 2, Delaware River Basin and tributaries to Delaware Bay: Water Data Report NJ-78-2, 302 p.

U.S. Geological Survey, 1979, Water-resources data for New Jersey, water years 1978, v. 1, Atlantic Slope Basins; Hudson River to Cape May: Water Data Report NJ-78-1, 121 p.

U.S. Geological Survey, 1980, Water-resources data for New Jersey, water years 1979, v. 1, Atlantic Slope Basins; Hudson River to Cape May: Water Data Report NJ-79-1, 347 p.

U.S. Geological Survey, 1980, Water-resources data for New Jersey, water years 1979, v. 2, Delaware River Basin and tributaries to Delaware Bay: Water Data Report NJ-79-2, 231 p.

U.S. Geological Survey, 1981, Water-resources data for New Jersey, water years 1980, v. 1, Atlantic Slope Basins; Hudson River to Cape May: Water Data Report NJ-80-1, 362 p.

U.S. Geological Survey, 1981, Water-resources data for New Jersey, water years 1980, v. 2, Delaware River Basin and tributaries to Delaware Bay: Water Data Report NJ-80-2, 287 p.

U.S. Geological Survey, 1982, Water-resources data for New Jersey, water years 1981, v. 1, Atlantic Slope Basins; Hudson River to Cape May: Water Data Report NJ-81-1, 329 p.

U.S. Geological Survey, 1982, Water-resources data for New Jersey, water years 1981, v. 2, Delaware River Basin and tributaries to Delaware Bay: Water Data Report NJ-81-2, $233 \mathrm{p}$.

Wahl, K.L., Thomas, W.O., and Hirsch, R.M., 1995, Streamgaging program of the U.S. Geological Survey: U.S. Geological Survey Circular 1123, 22 p.

Watson, K.M., Reiser, R.G., Nieswand, S.P., and Schopp, R.D., 2005, Streamflow characteristics and trends in New Jersey, water years 1897-2003: U.S. Geological Survey Scientific Investigations Report 2005-5105, 131 p. 
Watt, M.K., 2000, A hydrologic primer for New Jersey basin management: U.S. Geological Survey Water-Resources Investigations Report 2000-4140, 108 p.

White, B.T., Hoppe, H.L., Centinaro, G.L., Dudek, J.F., Painter, B.S., Protz, A.R., Reed, T.J., Shvanda, J.C., and Watson, A.F., 2006, Water resources data, New Jersey, water year 2005, v. 1, Surface-water data: U.S. Geological Survey Water-Data Report NJ-05-1, 408 p.

Wolfe, P.E., 1977, The geology and landscapes of New Jersey: Physics of the Earth and Planetary Interiors, v. 17, no. 4, p. 353-353. 
Appendix 1 
Appendix 1. Determination of preliminary baseline period for selected stream reaches in New Jersey (in water years) based on streamflow-gaging station history from published USGS annual data reports (1930-2005), and oral and written communications from USGS staff at the New Jersey Water Science Center.

[A water year is the 12-month period beginning October 1 and ending September 30 and is named for the year in which it ends. SB, South Branch; NB, North Branch]

\begin{tabular}{|c|c|c|c|}
\hline $\begin{array}{l}\text { Station } \\
\text { number }\end{array}$ & Station name & Comments & Years of record \\
\hline 01379000 & $\begin{array}{l}\text { Passaic River near } \\
\text { Millington, NJ }\end{array}$ & $\begin{array}{l}\text { Regulation since } 1979 \text { reduces flood peaks and augments low flow. Peri- } \\
\text { od of record before regulation selected as preliminary baseline period. }\end{array}$ & $1903-1979$ \\
\hline 01379500 & $\begin{array}{l}\text { Passaic River near } \\
\text { Chatham, NJ }\end{array}$ & $\begin{array}{l}\text { Diversions from Osborn Pond for municipal supply during water years } \\
\text { 1903-79 and substantial sewage discharge into stream since } 1970 . \\
\text { Period of record before } 1970 \text { selected as preliminary baseline period. }\end{array}$ & $1938-1970$ \\
\hline 01379773 & $\begin{array}{l}\text { Green Pond Brook at } \\
\text { Picatinny Arsenal, NJ }\end{array}$ & $\begin{array}{l}\text { Some minor regulation by Lake Denmark and Green Pond, but full } \\
\text { period of record selected as baseline period. }\end{array}$ & $1983-2005$ \\
\hline 01380500 & $\begin{array}{l}\text { Rockaway River above } \\
\text { Reservoir at Boonton, } \\
\text { NJ }\end{array}$ & $\begin{array}{l}\text { Flow has been regulated by Splitrock Reservoir and diversions have } \\
\text { been made from Taylortown Reservoir since the start of the period } \\
\text { of record. Substantial ground-water diversion in the basin has been } \\
\text { steadily increasing with development and increases in population } \\
\text { in the drainage basin. Sewage-treatment-plant outfall to the stream } \\
\text { above the gage was discontinued in } 1960 \text {. }\end{array}$ & $1937-1960$ \\
\hline 01381500 & $\begin{array}{l}\text { Whippany River at } \\
\text { Morristown, NJ }\end{array}$ & $\begin{array}{l}\text { Early on in the period of record, storm sewers entering the river in Mor- } \\
\text { ristown caused sharp rises in stage during runoff events and diurnal } \\
\text { patterns in low flows due to sewage effluent. After route I- } 287 \text { was } \\
\text { built in 1970, magnitude and frequency of peak flows increased } \\
\text { noticeably. Period of record before } 1970 \text { selected as preliminary } \\
\text { baseline period. }\end{array}$ & $1921-1970$ \\
\hline 01383500 & $\begin{array}{l}\text { Wanaque River at } \\
\text { Awosting, NJ }\end{array}$ & $\begin{array}{l}\text { Water has been diverted into the basin from the Upper Greenwood Lake } \\
\text { for municipal supply since } 1968 \text {. Period before } 1968 \text { selected as } \\
\text { preliminary baseline period. }\end{array}$ & 1969-2004 \\
\hline 01384500 & $\begin{array}{l}\text { Ringwood Creek near } \\
\text { Wanaque, NJ }\end{array}$ & $\begin{array}{l}\text { Minor regulation by Ringwood Mill Pond, Sterling Forest Lakes, and } \\
\text { several smaller retention basins upstream from the station. Entire } \\
\text { period of record selected as baseline period. }\end{array}$ & 1934-2004 \\
\hline 01385000 & $\begin{array}{l}\text { Cupsaw Brook near } \\
\text { Wanaque, NJ }\end{array}$ & $\begin{array}{l}\text { Minor regulation by Cupsaw Lake and Sheppard Pond. Entire period of } \\
\text { record selected as preliminary baseline period. }\end{array}$ & 1934-1958 \\
\hline 01386000 & $\begin{array}{l}\text { West Brook near } \\
\text { Wanaque, NJ }\end{array}$ & Entire period of record selected as preliminary baseline period. & 1934-1978 \\
\hline 01386500 & $\begin{array}{l}\text { Blue Mine Brook near } \\
\text { Wanaque, NJ }\end{array}$ & Entire period of record selected as preliminary baseline period. & 1934-1958 \\
\hline 01387000 & $\begin{array}{l}\text { Wanaque River at } \\
\text { Wanaque, NJ }\end{array}$ & $\begin{array}{l}\text { Substantial regulation since } 1928 \text {. Sewage effluent also enters stream } \\
\text { at multiple locations throughout the basin, which affects low flows. } \\
\text { Period of record before } 1928 \text { selected as preliminary baseline period. }\end{array}$ & 1918-1928 \\
\hline
\end{tabular}


Appendix 1. Determination of preliminary baseline period for selected stream reaches in New Jersey (in water years) based on streamflow-gaging station history from published USGS annual data reports (1930-2005), and oral and written communications from USGS staff at the New Jersey Water Science Center.-Continued

[A water year is the 12-month period beginning October 1 and ending September 30 and is named for the year in which it ends. SB, South Branch; NB, North Branch]

\begin{tabular}{|c|c|c|c|}
\hline $\begin{array}{l}\text { Station } \\
\text { number }\end{array}$ & Station name & Comments & Years of record \\
\hline 01387450 & $\begin{array}{l}\text { Mahwah River near } \\
\text { Suffern, NY }\end{array}$ & $\begin{array}{l}\text { Minor and occasional regulation from unknown sources. Entire period } \\
\text { of record selected as preliminary baseline period. }\end{array}$ & $1958-1995$ \\
\hline 01387500 & $\begin{array}{l}\text { Ramapo River near } \\
\text { Mahwah, NJ }\end{array}$ & $\begin{array}{l}\text { Since } 1979 \text {, flow substantially affected by pumping from ground-water } \\
\text { wells in areas of the drainage basin for municipal supply. Period of } \\
\text { record before } 1979 \text { selected as preliminary baseline period. }\end{array}$ & $1923-1979$ \\
\hline 01388000 & $\begin{array}{l}\text { Ramapo River at } \\
\text { Pompton Lakes, } \\
\text { NJ }\end{array}$ & $\begin{array}{l}\text { Water diverted since } 1953 \text { for municipal supply to Wanaque Reservoir. } \\
\text { Additional diversions to Oradell Reservoir since } 1985 \text {. Period of } \\
\text { record before } 1953 \text { selected as preliminary baseline period. }\end{array}$ & $1921-1953$ \\
\hline 01390500 & $\begin{array}{l}\text { Saddle River at } \\
\text { Ridgewood, } \\
\text { NJ }\end{array}$ & $\begin{array}{l}\text { Flow affected by ground-water withdrawals in the drainage basin since } \\
\text { 1964. Period of record before } 1964 \text { selected as preliminary baseline } \\
\text { period. }\end{array}$ & $1954-1964$ \\
\hline 01391000 & $\begin{array}{l}\text { Hohokus Brook at } \\
\text { Ho-Ho-Kus, NJ }\end{array}$ & $\begin{array}{l}\text { In } 1980 \text {, there was expansion of a sewage-treament plant contributing } \\
\text { substantial effluent to the stream which causes diurnal fluctuation } \\
\text { at medium and low flow. No data were available for } 1974 \text { to } 1977 \text {. } \\
\text { Therefore, to obtain a continuous period of record, the period before } \\
1974 \text { was selected as the baseline period. }\end{array}$ & $1954-1973$ \\
\hline 01391500 & $\begin{array}{l}\text { Saddle River at } \\
\text { Lodi, NJ }\end{array}$ & $\begin{array}{l}\text { Regulation since } 1965 \text { reduces flood peaks and augments low flow. Di- } \\
\text { version upstream from station for municipal supply and ground-water } \\
\text { withdrawal also affect flow, but specific year of influence is hard to } \\
\text { identify. Period of record before } 1965 \text { was selected for preliminary } \\
\text { baseline period. }\end{array}$ & $1923-1965$ \\
\hline 01392000 & $\begin{array}{l}\text { Weasel Brook at } \\
\text { Clifton, NJ }\end{array}$ & $\begin{array}{l}\text { Regulation and inflow from Garden State Parkway stormwater manage- } \\
\text { ment occurred since } 1950 \text {. Period of record before } 1950 \text { was selected } \\
\text { for preliminary baseline period. }\end{array}$ & $1937-1950$ \\
\hline 01392210 & $\begin{array}{l}\text { Third River at } \\
\text { Passaic, NJ }\end{array}$ & $\begin{array}{l}\text { Minor regulation from upstream ponds. Entire period of record selected } \\
\text { as preliminary baseline period. }\end{array}$ & $1977-1997$ \\
\hline 01392500 & $\begin{array}{l}\text { Second River at } \\
\text { Belleville, NJ }\end{array}$ & Entire period of record selected as preliminary baseline period. & $1937-1964$ \\
\hline 01396000 & $\begin{array}{l}\text { Robinsons Branch } \\
\text { at Rahway, NJ }\end{array}$ & $\begin{array}{l}\text { Diversions from Robinsons Branch continued until } 1970 \text { when water } \\
\text { supply was available from another location. Period of record after } \\
1970 \text { was selected as preliminary baseline period. }\end{array}$ & 1970-1996 \\
\hline 01396500 & $\begin{array}{l}\text { South Branch Raritan } \\
\text { River near High } \\
\text { Bridge, NJ }\end{array}$ & $\begin{array}{l}\text { Golf courses in the area contribute to regulation since around } 1970 \text {. } \\
\text { Period of record before } 1970 \text { selected as preliminary baseline period. }\end{array}$ & 1918-1970 \\
\hline 01396580 & $\begin{array}{l}\text { Spruce Run at Glen } \\
\text { Gardner, NJ }\end{array}$ & $\begin{array}{l}\text { Minor regulation from unknown sources upstream. Entire period of } \\
\text { record selected as preliminary baseline period. }\end{array}$ & $1978-2005$ \\
\hline
\end{tabular}


Appendix 1. Determination of preliminary baseline period for selected stream reaches in New Jersey (in water years) based on streamflow-gaging station history from published USGS annual data reports (1930-2005), and oral and written communications from USGS staff at the New Jersey Water Science Center.-Continued

[A water year is the 12-month period beginning October 1 and ending September 30 and is named for the year in which it ends. SB, South Branch; NB, North Branch]

\begin{tabular}{|c|c|c|c|}
\hline $\begin{array}{l}\text { Station } \\
\text { number }\end{array}$ & Station name & Comments & Years of record \\
\hline 01396660 & $\begin{array}{c}\text { Mulhockaway Creek } \\
\text { at Van Syckel, NJ }\end{array}$ & Entire period of record selected as preliminary baseline period. & $1977-2004$ \\
\hline 01397000 & $\begin{array}{l}\text { SB Raritan River at } \\
\text { Stanton, NJ }\end{array}$ & $\begin{array}{l}\text { Regulation from Spruce Run reservoir since 1963. Diversions to } \\
\text { reservoir pumping station since 1966. Period of record before } 1963 \\
\text { selected as preliminary baseline period. }\end{array}$ & $1919-1963$ \\
\hline 01397500 & $\begin{array}{l}\text { Walnut Brook near } \\
\text { Flemington, NJ }\end{array}$ & Entire period of record selected as preliminary baseline period. & $1936-1961$ \\
\hline 01398000 & $\begin{array}{l}\text { Neshanic River at } \\
\text { Reaville, NJ }\end{array}$ & $\begin{array}{l}\text { Minor regulation from irrigation pumpage and gradual substantial devel- } \\
\text { opment over the period. No other substantial change in anthropogenic } \\
\text { alteration of the stream or drainage basin could be determined; there- } \\
\text { fore, the entire period of record was selected as preliminary baseline } \\
\text { period. }\end{array}$ & $1930-2004$ \\
\hline 01398045 & $\begin{array}{c}\text { Back Brook Tributary } \\
\text { near Ringoes, NJ }\end{array}$ & Entire period of record selected as preliminary baseline period. & $1977-1988$ \\
\hline 01398107 & $\begin{array}{l}\text { Holland Brook at } \\
\text { Readington, NJ }\end{array}$ & Entire period of record selected as preliminary baseline period. & 1978-1996 \\
\hline 01398500 & $\begin{array}{l}\text { NB Raritan River near } \\
\text { Far Hills, NJ }\end{array}$ & $\begin{array}{l}\text { Occasional regulation and diversion affects streamflow. No other } \\
\text { substantial change from human alteration of the stream or drainage } \\
\text { basin could be determined; therefore, the entire period of record was } \\
\text { selected as preliminary baseline period. }\end{array}$ & $1921-2004$ \\
\hline 01399500 & $\begin{array}{c}\text { Lamington (Black) River } \\
\text { near Pottersville, NJ }\end{array}$ & Entire period of record selected as preliminary baseline period. & $1921-2004$ \\
\hline 01399510 & $\begin{array}{l}\text { Upper Cold Brook near } \\
\text { Pottersville, NJ }\end{array}$ & $\begin{array}{l}\text { Regulation by Pottersville Reservoir occurred until } 1982 \text { when the dam } \\
\text { was demolished. Period of record after } 1982 \text { was selected for prelimi- } \\
\text { nary baseline period. }\end{array}$ & 1982-1996 \\
\hline 01399525 & $\begin{array}{l}\text { Axle Brook near } \\
\text { Pottersville, NJ }\end{array}$ & Entire period of record selected as preliminary baseline period. & $1977-1988$ \\
\hline 01399670 & $\begin{array}{l}\text { South Branch Rockaway } \\
\text { Creek at Whitehouse } \\
\text { Station, NJ }\end{array}$ & $\begin{array}{l}\text { Releases from Round Valley Reservoir have affected stream during the } \\
\text { entire period of record. The entire period of record was selected as } \\
\text { preliminary baseline period. }\end{array}$ & $1977-2005$ \\
\hline
\end{tabular}


Appendix 1. Determination of preliminary baseline period for selected stream reaches in New Jersey (in water years) based on streamflow-gaging station history from published USGS annual data reports (1930-2005), and oral and written communications from USGS staff at the New Jersey Water Science Center.-Continued

[A water year is the 12-month period beginning October 1 and ending September 30 and is named for the year in which it ends. SB, South Branch; NB, North Branch]

\begin{tabular}{|c|c|c|c|}
\hline $\begin{array}{l}\text { Station } \\
\text { number }\end{array}$ & Station name & Comments & Years of record \\
\hline 01400000 & $\begin{array}{l}\text { North Branch Raritan } \\
\text { River near Raritan, NJ }\end{array}$ & $\begin{array}{l}\text { Intermittent releases from Round Valley Reservoir have affected stream } \\
\text { during the entire period of record. The entire period of record was } \\
\text { selected as preliminary baseline period. }\end{array}$ & 1923-2004 \\
\hline 01400350 & $\begin{array}{l}\text { Macs Brook at } \\
\text { Somerville, NJ }\end{array}$ & $\begin{array}{l}\text { Expansion of commercial development in the drainage basin occurred in } \\
\text { 1992. Streamflow was affected by stormwater management (regula- } \\
\text { tion by detention ponds). Period of record before } 1992 \text { was selected } \\
\text { as preliminary baseline period. }\end{array}$ & 1982-1992 \\
\hline 01400500 & $\begin{array}{l}\text { Raritan River at } \\
\text { Manville, NJ }\end{array}$ & $\begin{array}{l}\text { Regulation from Spruce Run Reservoir has occurred since 1963. Diver- } \\
\text { sions to Round Valley Reservoir and other locations have occurred } \\
\text { since 1966. After 1986, some diversions stopped. }\end{array}$ & 1921-1964 \\
\hline 01400730 & $\begin{array}{l}\text { Millstone River at } \\
\text { Plainsboro, NJ }\end{array}$ & $\begin{array}{l}\text { Minor diversion for irrigation occurred throughout the period. Entire } \\
\text { period of record selected as preliminary baseline period. }\end{array}$ & 1964-1975 \\
\hline 01401000 & $\begin{array}{l}\text { Stony Brook at } \\
\text { Princeton, NJ }\end{array}$ & $\begin{array}{l}\text { Sewage effluent is substantial during periods of increased develop- } \\
\text { ment. A period of accelerated increase in effluent is thought to have } \\
\text { occurred around } 1980 \text {. Period of record before } 1980 \text { was selected as } \\
\text { preliminary baseline period. }\end{array}$ & 1953-1980 \\
\hline 01401500 & $\begin{array}{l}\text { Millstone River near } \\
\text { Kingston, NJ }\end{array}$ & $\begin{array}{l}\text { During the entire period of record there were limited diversions to and } \\
\text { inflow from Delaware and Raritan Canal, slight regulation at up- } \\
\text { stream lake, and diurnal fluctuations at low flow at a gristmill above } \\
\text { the station. The entire period of record was selected as preliminary } \\
\text { baseline period. }\end{array}$ & 1933-1949 \\
\hline 01401650 & $\begin{array}{l}\text { Pike Run at Belle } \\
\text { Mead, NJ }\end{array}$ & $\begin{array}{l}\text { Substantial development in the basin occurred gradually throughout the } \\
\text { period of record. The entire period of record was selected as prelimi- } \\
\text { nary baseline period. }\end{array}$ & 1980-2005 \\
\hline 01402000 & $\begin{array}{l}\text { Millstone River at } \\
\text { Blackwells Mills, } \\
\text { NJ }\end{array}$ & $\begin{array}{l}\text { During the entire period of record, there was inflow from and losses to } \\
\text { the Delaware and Raritan Canal, and minor regulation from Carnegie } \\
\text { Lake and other smaller reservoirs. Sewage effluent increased dramati- } \\
\text { cally following development after around } 1960 \text {. Period of record } \\
\text { before } 1960 \text { was selected as preliminary baseline period. }\end{array}$ & $1921-1960$ \\
\hline 01402600 & $\begin{array}{r}\text { Royce Brook Tributary } \\
\text { near Belle Mead, NJ }\end{array}$ & $\begin{array}{l}\text { Regulation from stormwater detention basins upstream from the station } \\
\text { has occurred since } 1980 \text {. Period of record before } 1980 \text { was selected as } \\
\text { preliminary baseline period. }\end{array}$ & 1966-1980 \\
\hline 01403060 & $\begin{array}{l}\text { Raritan River below } \\
\text { Calco Dam at Bound } \\
\text { Brook, NJ }\end{array}$ & $\begin{array}{l}\text { Regulated by Spruce Run and Round Valley Reservoirs since } 1963 \text {. } \\
\text { Diversions have been made } 1.2 \text { miles upstream from station for } \\
\text { municipal supply throughout the period of record. Period of record } \\
\text { before } 1963 \text { was selected as preliminary baseline period. }\end{array}$ & $1902-1963$ \\
\hline 01403400 & $\begin{array}{l}\text { Green Brook at Seeley } \\
\text { Mills, NJ }\end{array}$ & $\begin{array}{l}\text { A dam upstream from the station has been a source of regulation } \\
\text { throughout the period of record. The entire period of record was } \\
\text { selected as preliminary baseline period. }\end{array}$ & 1979-2005 \\
\hline
\end{tabular}


Appendix 1. Determination of preliminary baseline period for selected stream reaches in New Jersey (in water years) based on streamflow-gaging station history from published USGS annual data reports (1930-2005), and oral and written communications from USGS staff at the New Jersey Water Science Center.-Continued

[A water year is the 12-month period beginning October 1 and ending September 30 and is named for the year in which it ends. SB, South Branch; NB, North Branch]

\begin{tabular}{|c|c|c|c|}
\hline $\begin{array}{l}\text { Station } \\
\text { number }\end{array}$ & Station name & Comments & Years of record \\
\hline 01403535 & $\begin{array}{l}\text { East Branch Stony } \\
\text { Brook at Best Lake } \\
\text { at Watchung, NJ }\end{array}$ & $\begin{array}{l}\text { A dam upstream from the station has been a source of regulation } \\
\text { throughout the period of record. The entire period of record was } \\
\text { selected as preliminary baseline period. }\end{array}$ & $1980-2000$ \\
\hline 01403540 & $\begin{array}{l}\text { Stony Brook at } \\
\text { Watchung, NJ }\end{array}$ & $\begin{array}{l}\text { Channel enlarged and modified in } 1991 \text {. Right wall of channel was } \\
\text { replaced in 1997. Period before } 1991 \text { was selected as preliminary } \\
\text { baseline period. }\end{array}$ & 1974-1991 \\
\hline 01405300 & $\begin{array}{l}\text { Matchaponix Brook } \\
\text { at Spotswood, NJ }\end{array}$ & $\begin{array}{l}\text { Flow past the station is affected by pumpage from well fields for nearby } \\
\text { industrial use. The time period and rate of increases of this pumpage } \\
\text { could not be determined. The entire period of record was selected as } \\
\text { preliminary baseline period. }\end{array}$ & $1957-1967$ \\
\hline 01408120 & $\begin{array}{l}\text { North Branch } \\
\text { Metedeconk River } \\
\text { near Lakewood, NJ }\end{array}$ & Entire period of record selected as preliminary baseline period. & $1972-2004$ \\
\hline 01408500 & $\begin{array}{l}\text { Toms River near } \\
\text { Toms River, NJ }\end{array}$ & $\begin{array}{l}\text { Diversion and regulation for industrial use occurred from 1966-1990. } \\
\text { Currently, additional minor regulation occurs from an unknown } \\
\text { source. Period of record before } 1966 \text { was selected as preliminary } \\
\text { baseline period. }\end{array}$ & $1928-1966$ \\
\hline 01409095 & $\begin{array}{l}\text { Oyster Creek near } \\
\text { Brookville, NJ }\end{array}$ & $\begin{array}{l}\text { Minor regulation from cranberry bogs. Entire period of record selected } \\
\text { as preliminary baseline period. }\end{array}$ & $1965-1985$ \\
\hline 01409280 & $\begin{array}{l}\text { Westecunk Creek at } \\
\text { Stafford Forge, NJ }\end{array}$ & $\begin{array}{l}\text { Minor regulation from upstream dam. Entire period of record selected as } \\
\text { preliminary baseline period. }\end{array}$ & $1973-1988$ \\
\hline 01409400 & $\begin{array}{l}\text { Mullica River near } \\
\text { Batsto, NJ }\end{array}$ & $\begin{array}{l}\text { Minor regulation from upstream cranberry bogs and Atison Lake. } \\
\text { Diversions from Sleeper Branch enter upstream from the station. No } \\
\text { substantial change from human alteration of the stream or drainage } \\
\text { basin could be determined from documented or known information. } \\
\text { Therefore, the entire period of record was selected as preliminary } \\
\text { baseline period. }\end{array}$ & $1957-2005$ \\
\hline
\end{tabular}


Appendix 1. Determination of preliminary baseline period for selected stream reaches in New Jersey (in water years) based on streamflow-gaging station history from published USGS annual data reports (1930-2005), and oral and written communications from USGS staff at the New Jersey Water Science Center.-Continued

[A water year is the 12-month period beginning October 1 and ending September 30 and is named for the year in which it ends. SB, South Branch; NB, North Branch]

\begin{tabular}{|c|c|c|c|}
\hline $\begin{array}{l}\text { Station } \\
\text { number }\end{array}$ & Station name & Comments & Years of record \\
\hline 01409500 & $\begin{array}{l}\text { Batsto River at } \\
\text { Batsto, NJ }\end{array}$ & $\begin{array}{l}\text { Regulation from sluice gates prior to } 1954 \text { and after } 1959 . \text { No substan- } \\
\text { tial change from human alteration of the stream or drainage basin } \\
\text { could be determined based on documented or known information; } \\
\text { therefore, the entire period of record was selected as preliminary } \\
\text { baseline period. }\end{array}$ & $1927-2005$ \\
\hline 01409810 & $\begin{array}{l}\text { West Branch Wading } \\
\text { River near Jenkins, NJ }\end{array}$ & $\begin{array}{l}\text { Minor regulation from cranberry bogs and small ponds. Entire period of } \\
\text { record selected as baseline period. }\end{array}$ & $1974-2005$ \\
\hline 01410000 & $\begin{array}{l}\text { Oswego River at } \\
\text { Harrisville, NJ }\end{array}$ & $\begin{array}{l}\text { Regulation from Harrisville Pond and cranberry bogs. Low flows also } \\
\text { are reduced by outflow of ground water to nearby drainage basins. } \\
\text { No years could be excluded from the baseline period as a result of } \\
\text { reviewing historical data. }\end{array}$ & $1930-2004$ \\
\hline 01410150 & $\begin{array}{r}\text { East Branch Bass River } \\
\text { near New Gretna, NJ }\end{array}$ & $\begin{array}{l}\text { Minor regulation by Lake Absegami. Entire period of record selected as } \\
\text { preliminary baseline period. }\end{array}$ & $1978-2005$ \\
\hline 01411000 & $\begin{array}{l}\text { Great Egg Harbor River } \\
\text { at Folsom, NJ }\end{array}$ & Entire period of record selected as preliminary baseline period. & $1925-2005$ \\
\hline 01411300 & $\begin{array}{l}\text { Tuckahoe River at Head } \\
\text { of River, NJ }\end{array}$ & $\begin{array}{l}\text { Minor regulation from upstream ponds. Entire period of record selected } \\
\text { as preliminary baseline period. }\end{array}$ & $1969-2004$ \\
\hline 01411456 & $\begin{array}{l}\text { Little Ease Run near } \\
\text { Clayton, NJ }\end{array}$ & Entire period of record selected as preliminary baseline period. & $1987-2005$ \\
\hline 01411500 & $\begin{array}{l}\text { Maurice River at Norma, } \\
\text { NJ }\end{array}$ & Entire period of record selected as preliminary baseline period. & $1932-2004$ \\
\hline 01412000 & $\begin{array}{l}\text { Menantico Creek near } \\
\text { Millville, NJ }\end{array}$ & $\begin{array}{l}\text { Minor regulation from unknown source. Earlier period of record } \\
\text { selected as preliminary baseline period. }\end{array}$ & $1931-1957$ \\
\hline 01412800 & $\begin{array}{l}\text { Cohansey River at } \\
\text { Seeley, NJ }\end{array}$ & $\begin{array}{l}\text { Minor regulation from lakes and irrigation. Entire period of record } \\
\text { selected as preliminary baseline period. }\end{array}$ & $1977-1988$ \\
\hline 01437500 & $\begin{array}{l}\text { Neversink River at } \\
\text { Godeffroy, NY }\end{array}$ & $\begin{array}{l}\text { Prior to } 1949 \text {, minor diurnal fluctuations at low flow caused by power } \\
\text { plant. Regulation from Neversink Reservoir has occurred since } 1954 \text {. } \\
\text { Currently, flow is diverted for municipal supply. Period of record } \\
\text { before } 1954 \text { was selected as preliminary baseline period. }\end{array}$ & $1937-1953$ \\
\hline 01440000 & $\begin{array}{l}\text { Flat Brook near } \\
\text { Flatbrookville, NJ }\end{array}$ & $\begin{array}{l}\text { Minor regulation from upstream ponds. Entire period of record selected } \\
\text { as preliminary baseline period. }\end{array}$ & $1923-2005$ \\
\hline 01443500 & $\begin{array}{l}\text { Paulins Kill at } \\
\text { Blairstown, NJ }\end{array}$ & $\begin{array}{l}\text { Minor regulation by Swartswood Lake and other ponds. Minor and } \\
\text { temporary fluctuations by unknown source. Entire period of record } \\
\text { selected as preliminary baseline period. }\end{array}$ & $1921-2004$ \\
\hline 01445000 & $\begin{array}{l}\text { Pequest River at } \\
\text { Huntsville, NJ }\end{array}$ & Entire period of record selected as preliminary baseline period. & $1939-1962$ \\
\hline
\end{tabular}


Appendix 1. Determination of preliminary baseline period for selected stream reaches in New Jersey (in water years) based on streamflow-gaging station history from published USGS annual data reports (1930-2005), and oral and written communications from USGS staff at the New Jersey Water Science Center.-Continued

[A water year is the 12-month period beginning October 1 and ending September 30 and is named for the year in which it ends. SB, South Branch; NB, North Branch]

\begin{tabular}{|c|c|c|c|}
\hline $\begin{array}{l}\text { Station } \\
\text { number }\end{array}$ & Station name & Comments & Years of record \\
\hline 01445500 & $\begin{array}{l}\text { Pequest River at } \\
\text { Pequest, } \mathrm{NJ}\end{array}$ & $\begin{array}{l}\text { Channel was dredged and realigned from } 1958 \text { to } 1960 \text { which has } \\
\text { altered peak discharges ever since. Period of record before } 1958 \text { was } \\
\text { selected as preliminary baseline period. }\end{array}$ & $1921-1958$ \\
\hline 01446000 & $\begin{array}{l}\text { Beaver Brook near } \\
\text { Belvidere, } \mathrm{NJ}\end{array}$ & Entire period of record selected as preliminary baseline period. & $1922-1961$ \\
\hline 01456000 & $\begin{array}{l}\text { Musconetcong River } \\
\text { near Hackettstown, NJ }\end{array}$ & $\begin{array}{l}\text { Minor regulation by Lake Hopatcong and other small lakes. Entire } \\
\text { period of record was selected as preliminary baseline period. }\end{array}$ & $1921-1973$ \\
\hline 01457000 & $\begin{array}{l}\text { Musconetcong River } \\
\text { near Bloomsbury, NJ }\end{array}$ & $\begin{array}{l}\text { Minor regulation by Lake Hopatcong. Entire period of record was } \\
\text { selected as preliminary baseline period. }\end{array}$ & 1903-2004 \\
\hline 01464500 & $\begin{array}{l}\text { Crosswicks Creek at } \\
\text { Extonville, NJ }\end{array}$ & $\begin{array}{l}\text { Minor regulation by upstream ponds. Entire period of record selected as } \\
\text { preliminary baseline period. }\end{array}$ & $1940-2005$ \\
\hline 01465850 & $\begin{array}{l}\text { South Branch Rancocas } \\
\text { Creek at Vincentown, } \\
\text { NJ }\end{array}$ & $\begin{array}{l}\text { Minor regulation by upstream ponds. Entire period of record selected as } \\
\text { preliminary baseline period. }\end{array}$ & $1961-1975$ \\
\hline 01466000 & $\begin{array}{l}\text { Middle Branch Mt } \\
\text { Misery Brook in Leba- } \\
\text { non State Forest, NJ }\end{array}$ & Entire period of record selected as preliminary baseline period. & $1952-1964$ \\
\hline 01467081 & $\begin{array}{l}\text { South Branch Pennsauken } \\
\text { Creek at Cherry } \\
\text { Hill, NJ }\end{array}$ & $\begin{array}{l}\text { Diurnal fluctuations occur at low flow owing to sewage effluent. Effect } \\
\text { of effluent has increased gradually during the period of record. No } \\
\text { years could be excluded from the preliminary baseline period on the } \\
\text { basis of historical information. }\end{array}$ & $1967-2004$ \\
\hline 01475000 & $\begin{array}{l}\text { Mantua Creek at } \\
\text { Pitman, NJ }\end{array}$ & $\begin{array}{l}\text { Minor regulation by Wadsworth Dam. Entire period of record selected } \\
\text { as preliminary baseline period. }\end{array}$ & $1940-1976$ \\
\hline 01477120 & $\begin{array}{l}\text { Raccoon Creek near } \\
\text { Swedesboro, NJ }\end{array}$ & $\begin{array}{l}\text { Minor regulation from irrigation. Entire period of record selected as } \\
\text { preliminary baseline period. }\end{array}$ & $1966-2005$ \\
\hline
\end{tabular}



For additional information, write to:

Director

U.S. Geological Survey

New Jersey Water Science Center

Mountain View Office Park

810 Bear Tavern Rd., Suite 206

West Trenton, NJ 08628

or visit our Web site at:

http://nj.usgs.gov/ 
